\title{
Intramedullary nails for extracapsular hip fractures in adults (Review)
}

\author{
Parker MJ, Handoll HHG
}

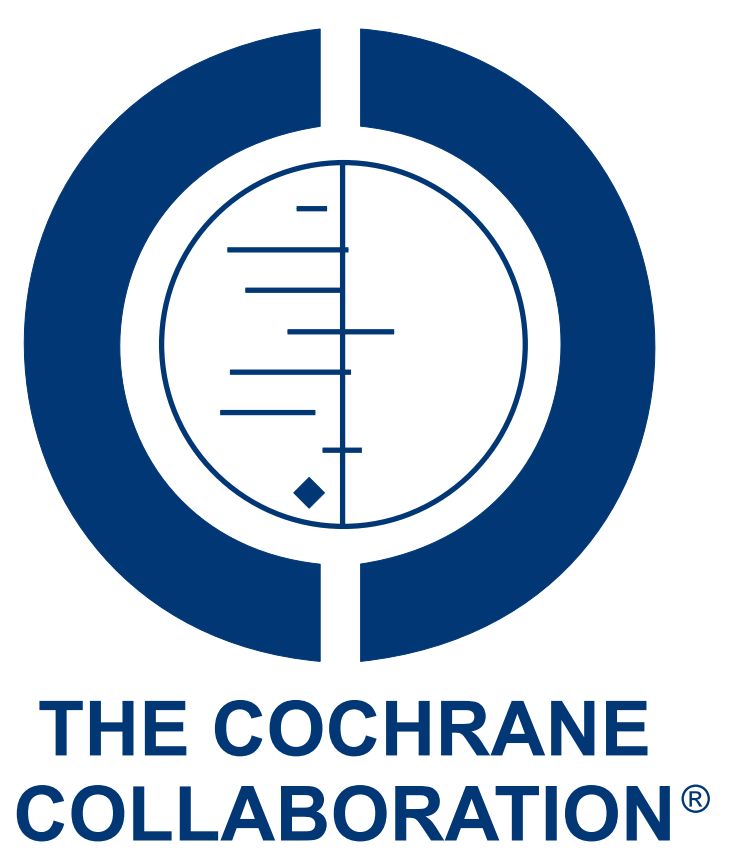

This is a reprint of a Cochrane review, prepared and maintained by The Cochrane Collaboration and published in The Cochrane Library 2008, Issue 4

http://www.thecochranelibrary.com

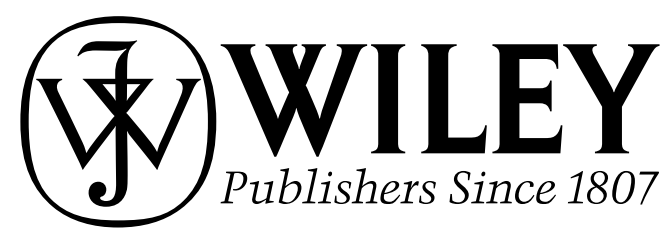

Intramedullary nails for extracapsular hip fractures in adults (Review)

Copyright (C) 2008 The Cochrane Collaboration. Published by John Wiley \& Sons, Ltd. 
TABLE OF CONTENTS

HEADER . . . . . . . . . . . . . . . . . . . . . . . . . . . . . . . . . . . . . . . 1

ABSTRACT . . . . . . . . . . . . . . . . . . . . . . . . . . . . . . . . . . . . . . . . . . . . . 1

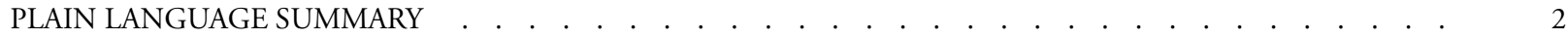

BACKGROUND . . . . . . . . . . . . . . . . . . . . . . . . . . . . . . . . . . . . . 2

OBJECTIVES . . . . . . . . . . . . . . . . . . . . . . . . . . . . . . . . . . 3

METHODS . . . . . . . . . . . . . . . . . . . . . . . . . . . . . . . . . . . . . .

RESULTS . . . . . . . . . . . . . . . . . . . . . . . . . . . . . . . . . . . . . . . 6

DISCUSSION . . . . . . . . . . . . . . . . . . . . . . . . . . . . . . . . . . . . . 10

AUTHORS' CONCLUSIONS . . . . . . . . . . . . . . . . . . . . . . . . . . . . . . . 11

ACKNOWLEDGEMENTS . . . . . . . . . . . . . . . . . . . . . . . . . . . . . . . . . . . . . . . . . 12

REFERENCES . . . . . . . . . . . . . . . . . . . . . . . . . . . . . . . . . . . . . 12

CHARACTERISTICS OF STUDIES . . . . . . . . . . . . . . . . . . . . . . . . . . . . . 13

DATA AND ANALYSES . . . . . . . . . . . . . . . . . . . . . . . . . . . . . . . . . . . . . . . . . . . . $\quad 24$

Analysis 1.1. Comparison 1 Proximal femoral nail (PFN) versus Gamma nail, Outcome 1 Operative details: length of surgery and blood loss. . . . . . . . . . . . . . . . . . . . . . . . . . . . . . . .

Analysis 1.2. Comparison 1 Proximal femoral nail (PFN) versus Gamma nail, Outcome 2 Number of patients transfused. Analysis 1.3. Comparison 1 Proximal femoral nail (PFN) versus Gamma nail, Outcome 3 Intra-operative complications. Analysis 1.4. Comparison 1 Proximal femoral nail (PFN) versus Gamma nail, Outcome 4 Fracture healing complications. Analysis 1.5. Comparison 1 Proximal femoral nail (PFN) versus Gamma nail, Outcome 5 Reoperation. . . . . . . Analysis 1.6. Comparison 1 Proximal femoral nail (PFN) versus Gamma nail, Outcome 6 Wound complications. 34 Analysis 1.7. Comparison 1 Proximal femoral nail (PFN) versus Gamma nail, Outcome 7 Post-operative complications. 35 Analysis 1.8. Comparison 1 Proximal femoral nail (PFN) versus Gamma nail, Outcome 8 Length of hospital stay (days). 36 Analysis 1.9. Comparison 1 Proximal femoral nail (PFN) versus Gamma nail, Outcome 9 Mortality. . . . . . $\quad . \quad 37$

Analysis 1.10. Comparison 1 Proximal femoral nail (PFN) versus Gamma nail, Outcome 10 Final functional outcomes. 38 Analysis 1.11. Comparison 1 Proximal femoral nail (PFN) versus Gamma nail, Outcome 11 Harris hip scores (0 to 100: high values = best function). . . . . . . . . . . . . . . . . . . . . . . . . . . . . .

Analysis 2.1. Comparison 2 ACE trochanteric nail versus Gamma nail, Outcome 1 Operative details: length of surgery, blood loss and radiographic screening time. . . . . . . . . . . . . . . . . . . . . . . . 39

Analysis 2.2. Comparison 2 ACE trochanteric nail versus Gamma nail, Outcome 2 Number of patients transfused. . 39 Analysis 2.3. Comparison 2 ACE trochanteric nail versus Gamma nail, Outcome 3 Fracture healing complications. . 40 Analysis 2.4. Comparison 2 ACE trochanteric nail versus Gamma nail, Outcome 4 Wound complications. . . . . 41 Analysis 2.5. Comparison 2 ACE trochanteric nail versus Gamma nail, Outcome 5 Post-operative complications. . $\quad 42$ Analysis 2.6. Comparison 2 ACE trochanteric nail versus Gamma nail, Outcome 6 Anatomical restoration. . . . . 42 Analysis 2.7. Comparison 2 ACE trochanteric nail versus Gamma nail, Outcome 7 Mortality. . . . . . . . . . . . 43 Analysis 2.8. Comparison 2 ACE trochanteric nail versus Gamma nail, Outcome 8 Final functional outcomes. . . 43 Analysis 2.9. Comparison 2 ACE trochanteric nail versus Gamma nail, Outcome 9 Mobility score (0: no difficulties to 9: most difficulties). . . . . . . . . . . . . . . . . . . . . . . . . . . . . . . . .

Analysis 2.10. Comparison 2 ACE trochanteric nail versus Gamma nail, Outcome 10 Harris hip scores (0 to 100: high values $=$ best function).

Analysis 3.1. Comparison 3 Gliding nail versus Gamma nail, Outcome 1 Fracture fixation complications. . . . . . Analysis 3.2. Comparison 3 Gliding nail versus Gamma nail, Outcome 2 Post-operative complications. . . . . . . . Analysis 3.3. Comparison 3 Gliding nail versus Gamma nail, Outcome 3 Anatomical deformity. ...... . Analysis 3.4. Comparison 3 Gliding nail versus Gamma nail, Outcome 4 Mortality at 6 months. . . . . . . . . Analysis 3.5. Comparison 3 Gliding nail versus Gamma nail, Outcome 5 Residence and unfavourable outcome (geriatric institution or death) at 6 months. . . . . . . . . . . . . . . . . . . . . . . . . . . .

Analysis 4.1. Comparison 4 Russell-Taylor Recon nail versus long Gamma nail, Outcome 1 Fracture healing and wound healing complications.

Analysis 4.2. Comparison 4 Russell-Taylor Recon nail versus long Gamma nail, Outcome 2 Final outcome measures. Analysis 5.1. Comparison 5 Dynamic versus static locked intramedullary nail, Outcome 1 Operative details. . . . . Analysis 5.2. Comparison 5 Dynamic versus static locked intramedullary nail, Outcome 2 Fracture fixation complications. . 6 s is , . . 济 
Analysis 5.3. Comparison 5 Dynamic versus static locked intramedullary nail, Outcome 3 Leg shortening $(\mathrm{mm})$ in those able to undergo a radiographic assessment. . . . . . . . . . . . . . . . . . . . . . . . . 50

Analysis 5.4. Comparison 5 Dynamic versus static locked intramedullary nail, Outcome 4 Mortality at 1 year. . . . 51

Analysis 5.5. Comparison 5 Dynamic versus static locked intramedullary nail, Outcome 5 Pain and cortical hypertrophy. 51

APPENDICES . . . . . . . . . . . . . . . . . . . . . . . . . . . . . . . . . . . . . 51

WHAT'S NEW . . . . . . . . . . . . . . . . . . . . . . . . . . . . . . . . . . . . . 53

HISTORY . . . . . . . . . . . . . . . . . . . . . . . . . . . . . . . . . . . . . . . 53

CONTRIBUTIONS OF AUTHORS . . . . . . . . . . . . . . . . . . . . . . . . . . . . . . . . . . . . . . . . 53

DECLARATIONS OF INTEREST . . . . . . . . . . . . . . . . . . . . . . . . . . . . . . . . . . . . . . $\quad 53$

SOURCES OF SUPPORT . . . . . . . . . . . . . . . . . . . . . . . . . . . . . . . . . . . . . . . . . . . . . 54

DIFFERENCES BETWEEN PROTOCOL AND REVIEW . . . . . . . . . . . . . . . . . . . . . . . . . . 54

INDEX TERMS . . . . . . . . . . . . . . . . . . . . . . . . . . . . . . . . . . . . . . . . . . 54 


\title{
[Intervention Review]
}

\section{Intramedullary nails for extracapsular hip fractures in adults}

\author{
Martyn J Parker ${ }^{1}$, Helen HG Handoll ${ }^{2}$ \\ ${ }^{1}$ Orthopaedic Department, Peterborough and Stamford Hospitals NHS Foundation Trust, Peterborough, UK. ${ }^{2}$ Centre for Rehabili- \\ tation Sciences (CRS), Research Institute for Health Sciences and Social Care, University of Teesside, Middlesborough, UK \\ Contact address: Martyn J Parker, Orthopaedic Department, Peterborough and Stamford Hospitals NHS Foundation Trust, Peterbor- \\ ough District Hospital, Thorpe Road, Peterborough, Cambridgeshire, PE3 6DA, UK. martyn.parker@pbh-tr.nhs.uk.
}

Editorial group: Cochrane Bone, Joint and Muscle Trauma Group.

Publication status and date: New search for studies and content updated (no change to conclusions), published in Issue 4, 2008.

Review content assessed as up-to-date: 28 June 2007.

Citation: Parker MJ, Handoll HHG. Intramedullary nails for extracapsular hip fractures in adults. Cochrane Database of Systematic Reviews 2006, Issue 3. Art. No.: CD004961. DOI: 10.1002/14651858.CD004961.pub3.

Copyright (C) 2008 The Cochrane Collaboration. Published by John Wiley \& Sons, Ltd.

\section{A B S T R A C T}

\section{Background}

Intramedullary nails may be used for the surgical fixation of extracapsular hip fractures in adults.

Objectives

To compare different types or design modifications of intramedullary nails used in the fixation of extracapsular hip fractures.

\section{Search strategy}

We searched the Cochrane Bone, Joint and Muscle Trauma Group Specialised Register (June 2007), the Cochrane Central Register of Controlled Trials (The Cochrane Library 2007, Issue 2), MEDLINE (1966 to June week 3 2007), EMBASE (1988 to 2007 Week 27), the UK National Research Register, Current Controlled Trials, orthopaedic journals, conference proceedings and reference lists of articles.

\section{Selection criteria}

All randomised or quasi-randomised trials comparing different types of intramedullary nails or modifications to the design of intramedullary nails in the treatment of extracapsular hip fractures in adults.

\section{Data collection and analysis}

Both authors independently assessed trial quality and extracted data. Additional information was sought from all trialists.

\section{Main results}

Nine studies, involving a total of 1290 predominantly female and older people with mainly unstable trochanteric fractures, were included. Allocation concealment was confirmed in only one trial.

Four studies (910 participants) compared the proximal femoral nail with the Gamma nail. There was no statistically significant difference between the two implants in operative fracture of the femur ( $1 / 455$ versus $5 / 455$; relative risk $0.33,95 \%$ confidence interval 0.07 to 1.63) nor differences for fracture healing complications, reoperations, other post-operative complications, mortality or function.

Two studies (185 participants) found no notable differences between the ACE nail versus the Gamma nail. One study (34 participants, all under 50 years) found no difference between the Recon nail versus the long Gamma nail. One study (80 participants) found no differences between a gliding nail versus a standard Gamma nail. Another study (81 participants) found no difference between a dynamically versus a statically locked intramedullary hip screw. 


\section{Authors' conclusions}

The limited evidence from the randomised trials undertaken to date is insufficient to determine whether there are important differences in outcome between different designs of intramedullary nails used in the internal fixation of extracapsular hip fractures. Given the evidence of superiority of the sliding hip screw compared with intramedullary nails for extracapsular hip fractures, further studies comparing different designs of intramedullary nails are not a priority. Any new design should be evaluated in a randomised comparison with the sliding hip screw.

\section{PLAIN LANGUAGE SUMMARY}

\section{Intramedullary nails for extracapsular hip fractures in adults}

Fractures of the upper part of the thigh bone (femur) are termed hip or proximal femoral fractures. Roughly half of all hip fractures are 'extracapsular' in that they lie outside the hip joint capsule. These fractures may be surgically fixed using metal implants. One type of implant is the 'intramedullary nail'. This consists of a metal rod, which is usually inserted from the upper end of the femur into the inner cavity (medulla) of the femur bone and held in place with screws.

This review assessed the evidence from nine randomised controlled trials that compared different designs of these nails. Four trials compared the proximal femoral nail with the Gamma nail in 910 older adults. Two trials involving 185 older adults compared the ACE intramedullary nail with the Gamma nail. One trial compared the Recon nail with the Gamma nail in 34 younger adults, all under 51 years old, with high-energy fractures such as from road traffic accidents. For all three comparisons there appeared to be no important differences in outcome between the two nails under test. One trial of 80 older adults looked at the effects of changing the design of one of the screws, and another trial of 81 older adults looked at the effects of changing one of the interlocking holes. Both these studies had too few participants to see if these changes in nail design had an important effect.

So far, the limited evidence from randomised controlled trials has not shown any important differences between the different designs of nails under test.

\section{B A C K G ROU N D}

Hip fracture is the general term for fracture of the proximal (upper) femur. These fractures can be subdivided into intracapsular fractures (those occurring within or proximal to the attachment of the hip joint capsule to the femur) and extracapsular (those occurring outside or distal to the hip joint capsule). Extracapsular hip fractures are defined as those fractures that occur within the area of bone bounded by the attachment of the hip joint capsule and extending down to a level which is five centimetres below the distal (lower) border of the lesser trochanter. Other terms used to describe these fractures include trochanteric, subtrochanteric, pertrochanteric and intertrochanteric fractures. These terms reflect the proximity of these fractures to the greater and lesser trochanters, which are two bony protuberances (bulges) at the upper end of the femur outside the joint capsule.

Numerous subdivisions and classification methods exist for these fractures (e.g. the AO classification (Muller 1991)). The most practical classification, and that used for this review, is the basic division into four types; stable trochanteric fractures (AO classification type A1), unstable trochanteric fractures (AO classification type A2), fractures at the level of the lesser trochanter (transtrochanteric or AO classification type A3) and subtrochanteric fractures. Stable trochanteric fractures are two part fractures in which the fracture line runs obliquely (at an angle) between the lesser and greater trochanter of the femur. Unstable trochanteric fractures again have an oblique fracture line running between the trochanters but in addition there is comminution (fragmentation) of the fracture site. The comminution fragments may be the lesser trochanter, greater trochanter or both trochanters. Transtrochanteric fractures, sited at the level of the lesser trochanter, have a slightly more distally located (lower) fracture line that either runs transversely (across the bone) at the level of the lesser trochanter or in an oblique di- 
rection that is opposite (or 'reverse') to that of the stable and unstable trochanteric fractures. Transtrochanteric fractures may be two part or comminuted. This fracture pattern is unstable as the femur is displaced medially (inwards) due to the pull of the abductor muscles. Subtrochanteric fractures are those fractures in which the fracture crossing the femur is predominately found within the five centimetres of bone immediately below the lesser trochanter. These fractures may be two part or comminuted and in some instances the fracture may extend proximally into the trochanteric region or distally into the shaft of the femur.

Operative treatment of hip fractures was introduced in the 1950s using a variety of different implants. Implants may be either extramedullary or intramedullary in nature. The most commonly used extramedullary implant is the sliding hip screw (SHS), which is synonymous with the term compression hip screw and equivalent models such as the Dynamic, Richards or Ambi hip screws. Intramedullary nails used for the internal fixation of extracapsular fractures can either be inserted from proximal to distal (cephalocondylic nails) or from distal to proximal (condylocephalic nails).

Cephalocondylic nails are inserted through the greater trochanter of the femur and secured by a cross pin or screw, which is passed up the femoral neck into the femoral head. A number of different designs have been developed and marketed by different manufacturers. Examples include the Gamma nail (Stryker-Howmedica), the intramedullary hip screw (Smith and Nephew Richards), the proximal femoral nail (Synthes) and the ACE trochanteric nail (DePuy Orthopaedics).

Successive updates of our Cochrane review (Parker 2008) comparing the Gamma and other cephalocondylic intramedullary nails with extramedullary implants for extracapsular hip fractures have consistently found that cephalocondylic nails incur the complications of intra-operative and later fracture around the implant. Based primarily on the higher rate of complications and reoperations of these nails for trochanteric fractures, we suggested that the SHS appears to be the better device for these fractures. We also suggested that "Further studies are required to determine if different types of intramedullary nail produce similar results, or if intramedullary nails have advantages for selected fracture types (for example, subtrochanteric fractures)."

Condylocephalic nails are inserted into the distal femur and passed up the intramedullary cavity across the fracture site and up into the femoral head. The best known and tested type of such nails is the Ender nail. Our Cochrane review of randomised trials comparing these implants with extramedullary fixation (Parker 1998) concluded that the use of condylocephalic nails could not be recommended because of the markedly increased risk of fracturehealing complications and other problems associated with condylocephalic nails (in particular Ender nails).

Despite the evidence of poor performance of intramedullary nails in comparison with the SHS, developments and modifications to intramedullary nails, especially cephalocondylic nails, continue. This systematic review of randomised trials examines studies that have compared different types, or modifications to the design, of intramedullary nails for extracapsular proximal femoral fractures.

\section{O B J E C T I VES}

Our objective was to compare the relative effects (benefits and harms) of different designs of intramedullary nails for the treatment of extracapsular proximal femoral fractures in adults.

\section{MET HO D S}

\section{Criteria for considering studies for this review}

\section{Types of studies}

All randomised or quasi-randomised (for example, alternation) controlled trials comparing different types of intramedullary nails.

\section{Types of participants}

Skeletally mature patients with an extracapsular proximal femoral fracture. Given that one of the authors (MJP) has become aware of the growing use of intramedullary nails in intracapsular fractures, we note here that in a future update we will consider including trials with a mixed population of intracapsular and extracapsular proximal femoral fractures. We will, however, request separate data for the two fracture types.

\section{Types of interventions}

Surgical fixation of the fracture with either a cephalocondylic intramedullary nail (for example, the Gamma nail, the intramedullary hip screw (IMHS) and the proximal femoral nail (PFN)) or a condylocephalic nail (for example, the Ender nail).

\section{Types of outcome measures}

The following outcomes were sought.

(1) Operative details

- length of surgery (in minutes)

- operative blood loss (in millilitres)

- number of patients transfused

- radiographic screening time (in seconds or minutes

(2) Fracture fixation complications

- operative fracture of the femur (around or below the implant, but excluding comminution of the fracture site) 
- later fracture of the femur (around or below the implant)

- cut-out of the implant from the femoral head

- non-union of the fracture

- breakage of the implant

- all technical complications of fixation (sum of above six outcomes with the addition of any other major complications of fracture healing as specified in each study. Major complications were defined as those which generally required revision surgery or a change of surgical procedure during the primary operation, such as using a longer nail. Excluded from this are minor operative complications such as comminution of the fracture site during surgery)

- other operative or fracture healing complications as detailed in individual studies

- re-operation (within the follow-up period of the study)

- superficial wound infection

- deep wound infection (i.e. infection around the implant)

- wound haematoma/seroma

(3) Post-operative complications and hospital stay

- pressure sores

- pneumonia

- thromboembolic complications (deep vein thrombosis or pulmonary embolism)

- any medical complication (as detailed in each individual study, excluding wound infections)

- length of hospital stay (in days)

(4) Anatomical restoration

- leg shortening (preferably $>2 \mathrm{~cm}$ )

- varus deformity of the femoral neck

- external rotation deformity (preferably $>20$ degrees)

(5) Final outcome measures

- mortality (within the follow-up period of the study)

- pain (persistent pain at the final follow-up assessment)

- mobility and use of walking aids

- failure to return to pre-fracture residential status

- functional activities of daily living

- composite function and hip scores

Data for any other outcomes as detailed in each individual study were also considered for inclusion.

\section{Search methods for identification of studies}

\section{Electronic searches}

We searched the Cochrane Bone, Joint and Muscle Trauma Group Specialised Register (June 2007), the Cochrane Central Register of Controlled Trials (The Cochrane Library 2007, Issue 2), MEDLINE (1966 to June week 3 2007) and EMBASE (1988 to 2007 Week 27). We searched the UK National Research Register (accessed June 2007) (http://www.update-software.com/National/ nrr-frame.html) and Current Controlled Trials at www.controlledtrials.com (accessed June 2007) for ongoing and recently completed trials. No language restriction was applied.

The general search strategies for hip fracture trials developed for The Cochrane Library (Wiley InterScience), MEDLINE (2002 onwards) and EMBASE (2002 onwards) are shown in Appendix 1. The hip fracture specific MEDLINE search was combined with all three stages of the Cochrane optimal trial search strategy (Higgins 2005a).

\section{Searching other resources}

We searched reference lists of articles and our own reference databases. We included the findings from handsearches of the British Volume of the Journal of Bone and Joint Surgery supplements (1996 onwards) and abstracts of the American Orthopaedic Trauma Association annual meetings (1996 to 2006: http://www.hwbf.org/ota/am/) and American Academy of Orthopaedic Surgeons annual meeting (2004 to 2007: www.aaos.org/ wordhtml/libscip.htm). We also included handsearch results from the final programmes of SICOT (1996 \& 1999) and SICOT/ SIROT (2003), EFFORT (2007) and the British Orthopaedic Association Congress (2000, 2001, 2002, 2003, 2005 and 2006). We scrutinised weekly downloads of "Fracture" articles in new issues of 15 journals (Acta Orthop Scand; Am J Orthop; Arch Orthop Trauma Surg; Clin J Sport Med; Clin Orthop; Foot Ankle Int; Injury; J Am Acad Orthop Surg; J Arthroplasty; J Bone Joint Surg Am; J Bone Joint Surg Br; J Foot Ankle Surg; J Orthop Trauma; J Trauma; Orthopedics) from AMEDEO (www.amedeo.com).

\section{Data collection and analysis}

\section{Selection of studies}

We independently assessed potentially eligible trials for inclusion. Titles of journals, names of authors or supporting institutions were not masked at any stage.

\section{Data extraction and management}

Using a data extraction form, we independently extracted data for the outcomes listed above and resolved any differences by discussion. We contacted all trialists for additional data and clarification when necessary. 


\section{Assessment of risk of bias in included studies}

We assessed each trial independently, without masking, for its quality of methodology and resolved any disagreement through discussion. The main assessment was the method of randomisation, which is also separately graded $\mathrm{A}, \mathrm{B}$ or $\mathrm{C}$ according to the scheme within the Cochrane Handbook (Higgins 2005b). In total, we assessed 10 aspects of methodology (see Table 1). From the first update (Issue 3, 2006) of the review, the scores of the individual items were no longer summed.

Table 1. Methodological quality assessment scheme

\begin{tabular}{l|l}
\hline Items & Scores \\
\hline 1. Was there clear concealment of allocation? & $\begin{array}{l}\text { Score 3 (and code A) if allocation was concealed (e.g. numbered } \\
\text { sealed opaque envelopes drawn consecutively). Score 2 (and code } \\
\text { B) if there was a possible chance of disclosure before allocation. } \\
\text { Score 1 (and code B) if the method of allocation concealment or } \\
\text { randomisation was not stated or was unclear. Score 0 (and code C) } \\
\text { if allocation concealment was clearly not concealed such as those } \\
\text { trials using quasi-randomisation (e.g. even or odd date of birth). }\end{array}$ \\
\hline
\end{tabular}

2. Were the inclusion and exclusion criteria clearly defined?

Score 1 if text states the type of fracture and which patients were included and/or excluded. Otherwise score 0 .

3. Were the outcomes of trial participants who withdrew or excluded after allocation described and included in an intention-totreat analysis?

Score 1 if yes or text states that no withdrawals occurred, or data are presented that, by clearly showing 'participant flow', allow this to be inferred. Otherwise score 0 .

4. Were the treatment and control groups adequately described at entry and if so were the groups well matched or appropriate covariate adjustment made?

Score 1 if at least four admission details given (e.g. age, sex, mobility, function score, mental test score, fracture type) with no significant difference between groups or appropriate adjustment made. Otherwise score 0.

5. Did the surgeons have experience of the operations they performed in the trial, prior to its commencement?

Score 1 if text states there was an introductory period or that surgeons were experienced. Otherwise score 0.

6. Were the care programmes other than trial options identical?

Score 1 if text states they were or if this can be inferred. Otherwise score 0 .

7. Were the outcome measures clearly defined in the text with a Score 1 if yes. Otherwise score 0.

definition of any ambiguous terms encountered?

8. Were the outcome assessors blind to assignment status?

Score 1 if assessors of pain and function at follow up were blinded to treatment outcome. Otherwise score 0 .

9. Was the timing of outcome measures appropriate?A minimum Score 1 if yes. Otherwise score 0. of six-months follow up for all surviving trial participants. 
Table 1. Methodological quality assessment scheme (Continued)

10. Was loss to follow up reported and if so were less than five per Score 1 if yes. Otherwise score 0. cent of trial participants lost to follow up?

\section{Measures of treatment effect}

For each study, we calculated relative risks (RR) with $95 \%$ confidence intervals for dichotomous outcomes, and mean differences with $95 \%$ confidence intervals for continuous outcomes.

\section{Assessment of heterogeneity}

Both the chi ${ }^{2}$ and $\mathrm{I}^{2}$ tests (Higgins 2003) as well as visual inspection were used to determine whether heterogeneity was present and whether data pooling was appropriate.

\section{Data synthesis}

Where appropriate, we pooled results of comparable groups of trials using both the fixed-effect and random-effects models.

\section{Sensitivity analysis}

There were insufficient data to conduct our planned exploratory sensitivity analyses based on allocation concealment and the reportage of surgical experience.

\section{R E S U L T S}

\section{Description of studies}

See: Characteristics of included studies; Characteristics of excluded studies; Characteristics of studies awaiting classification.

For this second update of this review, of four newly identified studies, three (Efstathopoulos 2007, Starr 2006; Vidyadhara 2007) were included and one (Suckel 2006) was excluded. Overall, a total of 13 studies were considered, nine of which are included. Three others are excluded for reasons given in the 'Characteristics of excluded studies'. One study (Gahr 2003) remains in 'Studies awaiting assessment' pending the receipt of further information. Eight included trials were reported in full in English language journals. A full translation from Spanish was obtained for the Marques 2005. Eight were single centre trials based in six different countries (Efstathopoulos 2007, Greece; Fritz 1999, Germany; Hardy 2003, Belgium; Herrera 2002, Spain; Marques 2005,
Spain; Papasimos 2005, Greece; Starr 2006, USA; Vidyadhara 2007, India). Schipper 2004 was a multicentre trial based in The Netherlands. Papasimos 2005 tested three implants: those patients allocated to the sliding hip screw are included in a separate Cochrane review (Parker 2008). Eight trials had predominantly older populations, with mean ages ranging between 69 and 83 years. The exception was Starr 2006, which only included adults under 50 years of age with high-energy fractures. Six trials (Fritz 1999; Hardy 2003; Schipper 2004; Marques 2005; Papasimos 2005; Vidyadhara 2007) included only patients with unstable trochanteric proximal femoral fractures, whereas a minority of patients in the other three trials (Efstathopoulos 2007; Herrera 2002; Starr 2006) had stable fractures. Further details of the nine included studies are given in the 'Characteristics of included studies'. The trials tested five different comparisons between a number of cephalocondylic nail designs. There were no trials evaluating condylocephalic nails.

\section{Proximal femoral nail (PFN) versus the Gamma nail}

The PFN was compared with the standard Gamma nail in 250 participants in Herrera 2002, in 156 participants in Marques 2005, in 80 participants in Papasimos 2005, and in 424 participants in Schipper 2004.

\section{ACE trochanteric nail versus the Gamma nail}

The ACE trochanteric nail was compared with the trochanteric Gamma nail in 112 participants in Efstathopoulos 2007, and with the Gamma AP nail in 73 participants in Vidyadhara 2007.

\section{'Gliding nail' versus the Gamma nail}

One trial (Fritz 1999) involving 80 participants compared the gliding nail (where the lag screw of a Gamma nail is replaced with a double T-shaped blade) with a standard Gamma nail.

\section{Russell-Taylor Recon nail versus the long Gamma nail}

One trial (Starr 2006) involving 34 participants compared the Russell-Taylor Recon nail with the long Gamma nail. 


\section{Dynamic versus static locked intramedullary nail}

One trial (Hardy 2003) involving 81 participants compared a modified intramedullary hip screw (IMHS) featuring a single slotted hole that allowed dynamic locking of the nail versus the standard IMHS, which is locked distally with two screws.

\section{Risk of bias in included studies}

Three trials (Fritz 1999; Hardy 2003; Papasimos 2005) did not specify their method of randomisation (item 1 of the scoring scheme). Allocation concealment appeared very likely in Schipper 2004, which used numbered and blinded envelopes: the randomisation sequence was computer-generated, stratified by participating centre and balanced in blocks of four and six patients. Both Efstathopoulos 2007 and Starr 2006 used sealed envelopes, these were reported to be numbered in Starr 2006. Vidyadhara 2007 used a computer-generated random numbers table. Herrera 2002 and Marques 2005 were quasi-randomised: allocation in both trials was based on odd and even record numbers. Fritz 1999, Marques 2005 Schipper 2004 and Starr 2006 reported that the surgeons involved were experienced with the procedures under investigation (item 5); the single surgeon in Vidyadhara 2007 also confirmed his prior experience. There was no specific report of prior experience of the surgeons with the implants being compared in the other trials: the majority of operations were carried out by junior surgeons in Hardy 2003. Assessor blinding (item 8) does not appear to have occurred in any of the trials. In Schipper 2004, follow up was discontinued at four months for participants with complete radiological consolidation; hence this trial scored zero for item 9 (timing of outcome measurement) despite the availability of oneyear follow-up data for the other participants of this trial.

The methodology assessment for the included studies rated according to the system described earlier (see Table 1) are given below:

12345678910 Trial name

2101011011 Efstathopoulos 2007

1111101011 Fritz 1999

1111011011 Hardy 2003

0001000010 Herrera 2002

0101111010 Marques 2005

1100011010 Papasimos 2005

3111111000 Schipper 2004

2111111010 Starr 2006

1111111011 Vidyadhara 2007

\section{Effects of interventions}

For this update, we were more successful in our attempts to obtain further information from the contact investigators of these trials. Previously, we received clarification of the method of randomisation used in Herrera 2002. For this update, we received some further details of methods and exact numbers of participants experiencing key outcomes from Marques 2005; and confirmation of the approach taken in the one-year analysis of Schipper 2004.

\section{Proximal femoral nail (PFN) versus the Gamma nail}

Four trials (Herrera 2002; Marques 2005; Papasimos 2005; Schipper 2004) compared the PFN with the standard Gamma nail in a total of 910 participants. All participants had unstable fractures other than 32 participants with stable fractures in Herrera 2002. Aside from Herrera 2002, which included 13 patients with "neoplasia", pathological fractures were excluded.

\section{(1) Operative details}

The mean length of surgery of the PFN group reported as being significantly shorter in Herrera 2002 (49 versus 68 minutes), whereas it was reported to be significantly longer in Papasimos 2005 (71 versus 51 minutes). The mean length of surgery was 60 minutes in both groups of Schipper 2004. Marques 2005 reported the difference between the two groups in the median length of surgery ( 45 versus 40 minutes) was not statistically significant.

Schipper 2004 found intra-operative blood loss was statistically significantly lower in the PFN group (mean difference $-67.00 \mathrm{ml}$, 95\% confidence interval (CI) -111.40 to $-22.60 \mathrm{ml}$ : see Analysis 1.1). Papasimos 2005 found the difference between the two groups in mean operative blood loss $(265 \mathrm{ml}$ versus $250 \mathrm{ml}$ ) was not statistically significant. Though significantly more participants in the PFN group of Herrera 2002 received blood transfusion, the converse was true for Marques 2005 (see Analysis 1.2). These results were not pooled since visual inspection of the transfusion results from the two trials shows substantial heterogeneity $\left(\mathrm{I}^{2}=88.9 \%\right.$ when pooled).

Neither trial reporting radiographic screening time found a statistically significant difference in this outcome between the two groups: for Marques 2005 the median times were 100 versus 120 seconds; for Papasimos 2005 the mean times were 0.26 minutes in both groups.

\section{(2) Fracture fixation complications}

Operative details as presented by each study are summarised in Analysis 1.3. None of the differences between the two groups in the various aspects and intra-operative complications of fracture fixation was statistically significant other than an increased risk of greater trochanteric fractures, or intra-operative comminution of the fracture around the trochanteric region, for those treated with the Gamma nail (see Analysis 01.03.06, 6/165 versus 20/165; RR $0.30,95 \%$ CI 0.12 to 0.73 ). Herrera 2002 did not reveal the surgical consequences of these fractures; both cases in Papasimos 2005 were treated conservatively. The difference between the two groups in the more important outcome of operative fracture of the 
femur was not statistically significant (see Analysis 01.03.07, 1/455 versus 5/455; RR 0.33, 95\% CI 0.07 to 1.63 ). Marques 2005 attributed all three intraoperative femoral fractures to bad surgical technique. The operative fracture in the Gamma nail group of Papasimos 2005 was managed conservatively. In Schipper 2004 both operative fractures of the femur, featuring a subtrochanteric extension, occurred in the Gamma nail group.

Analysis 1.4 presents the fracture healing complications as reported by each study. None of the differences in outcomes between the two implants in the pooled data from three or four studies was statistically significant. The tendency to a higher rate of secondary varus, reflecting a loss of reduction, in Herrera 2002 was stated as not being linked with subsequent clinical problems. The most common fracture healing complication was cut-out of the implant (17/455 versus $24 / 455$; RR $0.71,95 \%$ CI 0.39 to 1.30 ). It should be noted that in Schipper 2004, participants whose fractures were judged to be healed at four months had no further radiological follow up. There was no significant difference in the incidence of local complications, which included cut-out, infection, haematoma, migration of hip screws, malrotation, shaft fracture and nail fatigue, at four months in Schipper 2004 (45/211 versus 47/213); and similarly at 12 months $(51 / 211$ versus $50 / 213)$.

Pooled data from all four trials for reoperation showed no statistically significant difference between the two groups (see Analysis $1.5,45 / 455$ versus $36 / 455$; RR $1.25,95 \%$ CI 0.83 to 1.90 ). There were no significant differences between the two implants in any of the reported wound complications (see Analysis 1.6).

\section{(3) Post-operative complications and hospital stay}

None of the differences between the two implant groups in specific post-operative complications were statistically significant in Herrera 2002, Marques 2005 or Papasimos 2005 (see Analysis 1.7). Schipper 2004 reported no difference between groups in medical complications that had occurred by one-year follow up.

Herrera 2002 reported that trial participants remained in hospital for an average of 14.1 days. The mean length of stay in hospital was nearly a week longer in Schipper 2004; there being no significant difference between the two groups (see Analysis 1.8). Similarly, the difference between the two groups in the mean hospital stays were reported to be not statistically significant for both Marques 2005 (mean hospital stay: 11.1 days for the PFN group versus 12.2 days for the Gamma nail group) and Papasimos 2005 (8.6 days versus 8.8 days).

\section{(4) Anatomical restoration}

These outcomes were not reported in any of the trials. However, two participants of the PFN group and one of the Gamma nail group had reoperations for "rotational defect of the leg" in Herrera 2002.

\section{(5) Final outcome measures}

There was no statistically significant difference between the two groups in mortality at 12 months for the three trials that provided data (see Analysis 1.9, RR 1.08; 95\% CI 0.82 to 1.41 ). Papasimos 2005 excluded from their analyses the data from the 10 people who had died by one-year follow up.

The few functional outcome data that could be presented are shown in Analysis 1.10 and Analysis 1.11. Data from Herrera 2002 showed no statistically significant difference between the two groups in the failure to recover pre-fracture walking ability ( $R R$ 1.03 ; $95 \%$ CI 0.80 to 1.33 ). Pain in the thigh at follow up was reported as being statistically significantly less in the PFN group in Marques 2005 (4.7\% versus 27.3\%; reported $\mathrm{P}=0.004)$ but this difference was not apparent when the actual numbers of participants with pain were obtained from the trialist (see Analysis 1.10). Marques 2005 reported there was no statistically significant difference between the two groups in the final independent mobility scores. Papasimos 2005 reported there was no significant difference between the two groups in the return to pre-fracture level of ambulation and independence. The Harris hip scores at four weeks, six months and one year reported in Schipper 2004 showed no statistically significant difference between groups (see Analysis 1.11); however, this was for a subgroup of patients at each time point and thus may not be representative of the outcome for the population of survivors.

\section{ACE trochanteric nail versus Gamma nail}

Two trials (Efstathopoulos 2007; Vidyadhara 2007) made this comparison although with some variations in the intervention. Efstathopoulos 2007 compared the ACE nail used with one proximal screw versus the trochanteric Gamma nail in 112 people, $82 \%$ of whom had unstable fractures. In Vidyadhara 2007, the ACE nail had two proximal screws and was compared with the AP (Asian/pacific) Gamma nail in 73 people with unstable fractures. Neither study included subtrochanteric fractures.

\section{(1) Operative details}

Efstathopoulos 2007 reported no difference in the mean length of surgery between groups (see Analysis 2.1). Vidyadhara 2007 reported a higher median length of surgery for the ACE nail (43 versus 32 minutes). The statistically significantly greater blood loss found in Vidyadhara 2007 for the ACE nail is clinically minor (see Analysis 2.1: mean difference $13 \mathrm{ml}$; 95\% CI 6.78 to 19.22). Efstathopoulos 2007 found no statistically significant differences in the units of blood transfused, number of patients transfused or the radiographic screening time (see Analysis 2.1 and Analysis 2.2). 


\section{(2) Fracture fixation complications}

There were no fracture healing complications reported in Efstathopoulos 2007 and only one in Vidyadhara 2007 (see Analysis 2.3). This was a cut-out in the Gamma nail group that was treated by removal of the implant followed by bed rest for three months. Vidyadhara 2007 reported no wound infection whilst Efstathopoulos 2007 reported four cases of superficial wound infection in the ACE nail group versus three in the Gamma nail group (see Analysis 2.4).

\section{3) Post-operative complications and hospital stay}

There were no significant differences between the two groups in the limited data provided for post-operative complications (see Analysis 2.5). Efstathopoulos 2007 reported similar mean lengths of hospital stay for the two groups (7.2 versus 7.0 days; reported as not significant).

\section{(4) Anatomical restoration}

Three people had limb shortening in Vidyadhara 2007, with no significant differences between the two groups (see Analysis 2.6).

\section{(5) Final outcome measures}

There was no difference between the two groups in mortality (seeAnalysis 2.7 ). Vidyadhara 2007 found no statistically significant differences between the two groups in hip pain at one month after injury, or the presence of a limp or difficulty in squatting at two years (see Analysis 2.8). Efstathopoulos 2007 found no difference between the two groups in mobility scores at follow up (see Analysis 2.9). Although the Harris hip scores at 4 months, one year and two years were significantly different in the two groups of Vidyadhara 2007, the very small differences were clinically insignificant (see Analysis 2.10).

\section{'Gliding nail' versus the Gamma nail}

Fritz 1999 compared the gliding nail (a modification of the Gamma nail) with a standard Gamma nail. There were 40 participants, all with an unstable trochanteric fracture, in each group.

\section{(I) Operative details}

Fritz 1999 reported there were no statistically significant differences between the two groups for length of surgery (mean duration: 63 versus 62 minutes) or operative blood loss (mean loss: 338 versus $296 \mathrm{ml})$.

\section{(2) Fracture fixation complications}

There were no statistically significant differences between the two groups for these outcomes (see Analysis 3.1). There was one intraoperative complication (a minor shaft fracture) in the gliding nail group and seven intra-operative complications (six were due to failed placement of the second locking screw) in the Gamma nail group. One woman in the gliding nail group fell during mobilisation fracturing her femur shaft. Cut-out of the implant occurred in three cases in the standard nail group. Reoperations (3 versus 4) resulted from these two complications, as well as from wound infection and a haematoma.

\section{(3) Post-operative complications and hospital stay}

There were no statistically significant differences between the two groups in those with any post-operative medical complication or for specific complications as presented in Analysis 3.2. Fritz 1999 reported there was no statistically significant difference between the two groups in the mean hospital stay (9.2 versus 10.4 days).

\section{(4) Anatomical restoration}

There were no statistically significant differences between the two groups in those with leg shortening or rotational deformity (see Analysis 3.3).

\section{(5) Final outcome measures}

No statistically significant difference was found between the two groups for mortality (see Analysis 3.4), for residence of survivors in a geriatric institution (see Analysis 3.5) or overall unfavourable outcome, defined as residence in a geriatric institution or dead, at six months. Fritz 1999 reported there were no statistically significant differences between the two groups in the Merle d'Aubigne scores for pain, walking function, mobility or overall.

\section{Russell-Taylor Recon nail versus long Gamma nail}

Starr 2006 compared the Russell-Taylor Recon nail with the long Gamma nail in 34 people, aged between 19 and 50 years, with high energy extracapsular hip fracture. Five trial participants had stable and 21 unstable trochanteric fractures, and the other eight had subtrochanteric fractures. Three patients had open fractures and 17 had concurrent surgery for other injuries.

\section{(I) Operative details}

Starr 2006 reported there were no statistically significant differences between the two groups for length of surgery (mean duration: 106 versus 88 minutes; reported $\mathrm{P}=0.26$ ) or operative blood loss (mean loss: 328 versus $282 \mathrm{ml}$; reported $\mathrm{P}=0.15$ ). 


\section{(2) Fracture fixation complications}

There were no fracture fixation complications reported (see Analysis 4.1). One patient in the long Gamma nail group had wound debridement for sepsis and a further 12 patients had elective removal of their implants for persistent pain (see Analysis 4.1).

\section{(3) Post-operative complications and hospital stay}

These outcomes were not reported in Starr 2006.

\section{(4) Anatomical restoration}

These outcomes were not reported in Starr 2006.

\section{(5) Final outcome measures}

No deaths occurred within the one year follow-up period. Starr 2006 found no statistically significant differences between the two groups in the numbers of participants who were unable to walk independently or unable to return to the same work (see Analysis 4.2). The person who was unable to walk had sustained a spinal cord injury at the time of her initial trauma. Similarly, there were no statistically significant difference between the two groups in the range of hip or knee movements. The Harris hip scores were similar for the two groups (mean scores: 86 versus 84; reported P $=0.60$ ).

\section{Dynamic versus static locked intramedullary nail}

Hardy 2003 compared a dynamically locked intramedullary hip screw (IMHS) which was allocated to 42 patients, with the usual statically locked IMHS allocated to 39 patients.

\section{(I) Operative details}

There were no statistically significant differences between the two groups for length of surgery, operative blood loss, haemoglobin levels or transfusion requirements (see Analysis 5.1).

\section{(2) Fracture fixation complications}

There were no statistically significant differences between the two groups for these outcomes (see Analysis 5.2). Cut-out of the implant occurred in one case in the dynamic group and a fracture below the tip in one case in the static group. Reoperations ( 1 versus 3) resulted from these two complications as well as from two operations for hardware removal in the static group.

\section{(3) Post-operative complications and hospital stay}

Medical complications and length of hospital stay were not reported in Hardy 2003. Though there were some discrepancies between text and tables in the trial report for discharge destination and in-hospital deaths, there was clearly no difference between the two groups in these outcomes.

\section{(4) Anatomical restoration}

Incomplete data for leg shortening (see Analysis 5.3) showed no statistically significant difference between the two groups. (Subsidence of the nail in the femoral shaft was seen in nine participants of the dynamic group compared with none in the static group.) No information on deformity was presented in Hardy 2003.

\section{(5) Final outcome measures}

No statistically significant difference was found between the two groups for mortality (see Analysis 5.4). Pain in the mid-thigh region was reported at follow up for two participants of the dynamic group and six in the static group (see Analysis 5.5). The pain impaired walking in four of the latter group. All six participants reporting mid-thigh pain in the static group had cortical hypertrophy. The other instance of cortical hypertrophy occurred in a participant of the dynamic group who did not report midthigh pain. Hardy 2003 reported similar results in the two groups for accommodation, mobility scores and independence rating of survivors at one year.

\section{DISCUSSION}

The nine trials included in this review, involving a total of 1290 predominantly female and older people with predominantly unstable trochanteric fractures, tested five different comparisons. No notable differences were found for each comparison either in the individual trials or where data could be pooled. However, in each case there were insufficient patient numbers to rule out important differences. It is noteworthy that this review is predominantly a set of comparisons of intramedullary nails from different manufacturers. Thus, it could be conjectured that it is primarily the market place that has set the research agenda and associated aims of these underpowered trials. Comments on each of the comparisons are provided below.

\section{Proximal femoral nail (PFN) versus the Gamma nail}

Herrera 2002 was a quasi-randomised trial whose report did not provide a satisfactory account of trial methods, particularly to confirm intention-to-treat analysis. Marques 2005 was also a quasi- 
randomised trial. The inconsistencies between the percentages presented in the trial report and the data received subsequently for Marques 2005 show the importance of presenting a participant flow diagram, as done by Schipper 2004. A participant flow diagram would also have helped in Papasimos 2005, where the baseline and early outcome results were not provided for 21 participants. Particular caution is required on viewing the results of these two trials. While Schipper 2004 recruited 424 patients, their decision to only follow up trial participants with non-consolidated fractures after four months considerably reduced the numbers available at one year.

The only statistically significant difference arising from pooled data was an increased risk of greater trochanteric fractures, or intraoperative comminution of the fracture around the trochanteric region, for those treated with the Gamma nail (see Analysis 01.03.06, 6/165 versus $20 / 165$; RR $0.30,95 \%$ CI 0.12 to 0.73 ). This result is dominated by the results of Herrera 2002 (5/125 versus 19/125), which did not reveal the surgical consequences of these fractures. It is likely that these were of no clinical significance. Both cases in Papasimos 2005 were treated conservatively. The difference between the two groups in the more important outcome of operative fracture of the femur was not statistically significant (RR $0.33,95 \%$ CI 0.07 to 1.63 ).

Schipper 2004 acknowledged the high revision rates, for both implants, in their study but stressed their inclusion of exclusively unstable fractures. Indeed their reoperation rate $(9.2 \%$ at four months; $11.8 \%$ at one year) is high, and it is notable that it is markedly higher than that (5.4\%) reported for short femoral nails or, indeed, the SHS (3.4\%) (Parker 2008). At 10\%, the overall reoperation rate for Papasimos 2005 was also high. The overall reoperation rate for Herrera 2002 was 6.0\%; excluding stable fractures it was $6.8 \%$. For Marques 2005, the reoperation rate was $5.1 \%$.

\section{ACE trochanteric nail versus Gamma nail}

The two studies addressing this comparison used different implants or techniques and had different populations. The only fracture fixation complication reported was a cut-out which resulted in a re-operation in Vidyadhara 2007. The outcome of this trial, which had no deaths or loss to follow up, was otherwise very favourable for both groups as shown by the usually high Harris hip scores with very little variation within each group. Supposing that the correct statistics were presented, the clinical significance of the statistically significant differences in blood loss and Harris hip scores is questionable in Vidyadhara 2007. Coupled with the other findings of no differences between the implants in these two small trials, no definite conclusions can be drawn on the relative effectiveness of the two implants.

\section{'Gliding nail' versus the Gamma nail}

The gliding nail was designed to avoid the complications of implants such as the Gamma nail by virtue of an enlarged surface area for load transmission and a higher stability. Whilst cut-out of the implant was less in the gliding nail group ( $3 / 40$ versus $0 / 40$ ), no definite conclusions can be drawn from this study on whether the gliding nail actually reduces the risk of fixation complications relative to the Gamma nail due the limited number of study participants.

\section{Russell-Taylor Recon nail versus long Gamma nail}

The single study included people with high energy fractures aged between 18 and 50 years; 17 of whom had concurrent surgery for other injuries. Thus, this was a very different population to the other trials in this review. There was a high rate of elective removal of implants for pain compared with the other trials. Though Starr 2006 found no notable differences in outcomes or complications between the two implants it is too small to conclude this is a true finding.

\section{Dynamic versus static locked intramedullary nail}

Though none of the differences between the two groups reached statistical significance, Hardy 2003 suggested that lower incidence of cortical hypertrophy of the bone at the level of the distal locking screws in the dynamic group was linked with the lower number of participants with mid-thigh pain in the dynamic group. However, though this suggestion is plausible, the limited number of study participants mean that no firm conclusions can be made regarding the effects of dynamic compared with static locking of the IMHS.

\section{AUTHORS' CONCLUSIONS}

\section{Implications for practice}

There was insufficient evidence from randomised trials to determine if there are important differences in patient outcomes between the different designs of proximal femoral intramedullary nail produced by different manufacturers when used for the fixation of unstable trochanteric fractures.

\section{Implications for research}

Given the evidence indicating the current superiority of the sliding hip screw (SHS) over intramedullary nails for trochanteric fractures (Parker 2008), it is debatable whether studies comparing different types or aspects of intramedullary nails design should be 
undertaken. Nonetheless, while we suggest that further development and modification of cephalocondylic nails for these fractures is not a priority, any new developments should be evaluated using robust methodology with adequate patient numbers. We suggest the choice of comparator of any such trial should be the SHS.

\section{ACKNOWLEDGEMENTS}

We would like to thank the following for their comments and help at editorial and external review of the review and subsequent updates: Piet de Boer, Rebecca Coghlan, Lindsey Elstub, Bill Gillespie, Lesley Gillespie, Peter Herbison, Rajan Madhok and Janet Wale. We thank Lesley Gillespie and Joanne Elliott for help with the search for trials and the search strategy.

We would like to thank the following for their comments at editorial review of the protocol: Rebecca Coghlan, Lesley Gillespie and Rajan Madhok. We also thank Luisa Fernandez Mauleffinch for the translation of Marques 2005.

\section{R E F E R E N C E S}

\section{References to studies included in this review}

Efstathopoulos 2007 \{published data only\}

Efstathopoulos N, Nikolaou V, Lazarettos J, Psixas X, Xypnitos F, Papachristou G. Intramedullary fixation of pertrochanteric hip fractures: A comparison of two implant designs. Journal of Bone and Joint Surgery - British Volume 2006;88 Suppl 1:70.

* Efstathopoulos NE, Nikolaou VS, Lazarettos JT. Intramedullary fixation of intertrochanteric hip fractures: A comparison of two implant designs. International Orthopaedics 2007;31(1):71-6.

Fritz 1999 \{published data only\}

Fritz T, Hiersemann K, Krieglstein C, Friedl W. Prospective randomized comparison of gliding nail and gamma nail in the therapy of trochanteric fractures. Archives of Orthopaedic and Trauma Surgery 1999;119(1):1-6.

Hardy 2003 \{published data only\}

Hardy DC, Drossos K. Slotted intramedullary hip screw nails reduce proximal mechanical unloading. Clinical Orthopaedics and Related Research 2003;(406):176-84.

Herrera 2002 \{published and unpublished data\}

Herrera A. personal communication September 282004.

* Herrera A, Domingo LJ, Calvo A, Martinez A, Cuenca J. A comparative study of trochanteric fractures treated with the Gamma nail or the proximal femoral nail. International Orthopaedics 2002;26(6):365-9.

Marques 2005 \{published and unpublished data\}

Marques F. personal communication May 182005.

* Marques F, Leon A, Mestre C, Balliester J, Caceres E. Prospective comparative study of the intertrochanteric Gamma nail and AO proximal femoral nail in the treatment of unstable intertrochanteric fractures [Estudio prospectivo comparativo entre el clavo gamma trocanterico y el clavo femoral proximal AO (PFN) en el tratamiento de las fracturas trocantericas inestables]. Revista de Ortopedia y Traumatologia 2005;49(1):11-6.

Papasimos 2005 \{published data only\} Papasimos S, Koutsojannis CM, Panagopoulos A, Megas P, Lambiris E. A randomised comparison of the AMBI, TGN and PFN for treatment of unstable trochanteric fractures. Archives of Orthopaedic and Trauma Surgery 2005;125(7):462-8.

Schipper 2004 \{published data only\}

Schipper I. personal communication January 192006.

* Schipper IB, Steyerberg EW, Castelein RM, van der Heijden FH, den Hoed PT, Kerver AJ, et al.Treatment of unstable trochanteric fractures. Randomised comparison of the gamma nail and the proximal femoral nail. Journal Bone and Joint Surgery - British Volume 2004;86(1):86-94.

\section{Starr 2006 \{published and unpublished data\}}

Starr A. personal communication July 232007.

* Starr AJ, Hay MT, Reinert CM, Borer DS, Christensen KC. Cephalomedullary nails in the treatment of high-energy proximal femur fractures in young patients: A prospective, randomized comparison of trochanteric versus piriformis fossa entry portal. Journal of Orthopaedic Trauma 2006;20(4):240-6.

Vidyadhara 2007 \{published and unpublished data\}

Vidyadhara S. personal communication August 82007.

* Vidyadhara S, Roa SK. One and two femoral neck screws with intramedullary nails for unstable trochanteric fractures of femur in the elderly-Randomised clinical trial. Injury 2007;38(7):806-14. 


\section{References to studies excluded from this review}

Merenyi 1995 \{published data only\}

Merenyi G, Zagh I, Kovacs A. Gamma nail versus Ender nails and angle-plate in the proximal fractures of the femur - a randomised prospective study [abstract]. Journal of Bone and Joint Surgery British Volume 1995;77(Suppl 3):215.

Suckel 2006 \{published data only\}

Suckel A, Munst P, Mocke U. Rotationally stable, intramedullary osteosynthesis of proximal extra-articular femur fractures [Die rotationsstabile intramedullare osteosynthese von proximalen extraartikularen femurfrakturen]. Zeitschrift fur Orthopadie und Ihre Grenzgebiete 2006;144(5):532-8.

\section{Wagner 1998 \{published data only\}}

Wagner R, Blattert TR, Weckbach A. Solution to the problem of extra-articular, femoral hip fracture by the "sliding screw-nail principle”. Results of 2 different systems (classical nail and gamma nail) [Problemlosung der extraartikularen, koxalen femurfraktur durch das "Gleitschrauben-Nagel-Prinzip". Ergebnisse zweier verschiedener systeme (classic nail und gamma-nagel)]. Unfallchirurg 1998;101(12):894-900.

\section{References to studies awaiting assessment}

Gahr 2003 \{published data only\}

Gahr RH, Pawelka A. Employing a modified gamma nail for the treatment of proximal femoral fractures [Einsatz eines modifizierten Gammanagels bei der versorgung proximaler femurfrakturen. Neuer "long gamma nail" $10 \mathrm{~mm}$ vs. "long gamma nail" 11 mm-eine prospektive studie]. Unfallchirurg 2003;106(7):550-5.

\section{Additional references}

\section{Higgins 2003}

Higgins JP, Thompson SG, Deeks JJ, Altman DG. Measuring inconsistency in meta-analyses. BMJ 2003;327:557-60.

\section{Higgins 2005a}

Higgins JPT, Green S, editors. Highly sensitive search strategies for identifying reports of randomized controlled trials in MEDLINE. Cochrane Handbook for Systematic Reviews of Interventions 4.2.5 [updated May 2005]; Appendix 5b. www.cochrane.org/resources/ handbook/hbook.htm (accessed 01 May 2007).

\section{Higgins 2005b}

Higgins JPT, Green S, editors. Selection bias. Cochrane Handbook for Systematic Reviews of Interventions 4.2.5 [updated May 2005]; Section 6.3. www.cochrane.org/resources/handbook/hbook.htm (accessed 01 May 2007).

\section{Muller 1991}

Muller ME. Appendix A. The comprehensive classification of fractures of long bones. In: Allgower M editor(s). Manual of internal fixation: techniques recommended by the AO-ASIF Group. 3rd Edition. Berlin: Springer-Verlag, 1991:118-50.

\section{Parker 1998}

Parker MJ, Handoll HHG. Condylocephalic nails versus extramedullary implants for extracapsular hip fractures. Cochrane Database of Systematic Reviews 1998, Issue 4. [DOI: DOI: 10.1002/ 14651858.CD000338]

\section{Parker 2008}

Parker MJ, Handoll HHG. Gamma and other cephalocondylic intramedullary nails versus extramedullary implants for extracapsular hip fractures in adults. Cochrane Database of Systematic Reviews 2008, Issue 3. [DOI: 10.1002/ 14651858.CD000093.pub4]

\section{References to other published versions of this review}

\section{Parker 2004}

Parker MJ, Handoll HHG. Cephalocondylic intramedullary nails for extracapsular hip fractures in adults (protocol). Cochrane Database of Systematic Reviews 2004, Issue 4.

\section{Parker 2005}

Parker MJ, Handoll HHG. Intramedullary nails for extracapsular hip fractures in adults. Cochrane Database of Systematic Reviews 2005, Issue 2.[Art. No.: CD004961. DOI: 10.1002/ 14651858.CD004961.pub3]

\section{Parker 2006}

Parker MJ, Handoll HHG. Intramedullary nails for extracapsular hip fractures in adults. Cochrane Database of Systematic Reviews 2006, Issue 3.[Art. No.: CD004961. DOI: 10.1002/ 14651858.CD004961.pub3]

* Indicates the major publication for the study 
CHARACTERISTICS OF STUDIES

\section{Characteristics of included studies [ordered by study ID]}

\section{Efstathopoulos 2007}

\begin{tabular}{|c|c|c|}
\hline Methods & \multicolumn{2}{|c|}{$\begin{array}{l}\text { Randomised trial: sealed envelopes } \\
\text { Length of follow up: mean } 8 \text { months (range } 6 \text { to } 12 \text { months) }\end{array}$} \\
\hline Participants & \multicolumn{2}{|c|}{$\begin{array}{l}\text { Orthopaedic hospital, Athens, Greece } \\
112 \text { people aged } 65 \text { or over with a trochanteric proximal femoral fracture (Jensen types I and II : stable } \\
\text { (18\%), or III and IV: unstable ( } 82 \%) \text { ) } \\
\text { Age: mean } 78 \text { years (range } 69 \text { to } 89 \text { years) } \\
\% \text { male: } 29 \% \\
\text { Number lost to follow up: } 5(4.5 \%) \\
\text { Assigned: } 56 / 56 \text { [ACE trochanteric nail / trochanteric Gamma nail] }\end{array}$} \\
\hline Interventions & \multicolumn{2}{|c|}{$\begin{array}{l}\text { ACE trochanteric nail versus a trochanteric Gamma nail. } \\
\text { The ACE nail was } 11 \mathrm{~mm} \text { diameter, inserted without reaming and with one proximal screw and one } \\
\text { distally locking screw. The Gamma nail was } 11 \mathrm{~mm} \text { distal diameter, and inserted with reaming and had } \\
\text { one distal locking screw. }\end{array}$} \\
\hline Outcomes & \multicolumn{2}{|c|}{$\begin{array}{l}\text { Length of surgery } \\
\text { Units of blood transfused } \\
\text { Number of patients transfused } \\
\text { Radiographic screening time } \\
\text { Cut-out of implant } \\
\text { Operative fracture of femur } \\
\text { Later fracture of the femur } \\
\text { Non-union } \\
\text { Reoperation } \\
\text { Wound infection } \\
\text { Deep wound infection } \\
\text { Deep vein thrombosis } \\
\text { All medical complications } \\
\text { Length of hospital stay } \\
\text { Mortality } \\
\text { Mobility }\end{array}$} \\
\hline Notes & \multicolumn{2}{|c|}{$\begin{array}{l}\text { The trial report clearly states that there were no fracture healing complications: the outcome of no } \\
\text { reoperations was inferred from this. }\end{array}$} \\
\hline \multicolumn{3}{|l|}{ Risk of bias } \\
\hline Item & Authors' judgement & Description \\
\hline Allocation concealment? & Unclear & B - Unclear \\
\hline
\end{tabular}


Fritz 1999

\begin{tabular}{|c|c|c|}
\hline Methods & \multicolumn{2}{|c|}{$\begin{array}{l}\text { Randomised trial: method not stated except that it was "non-stratified" } \\
\text { Length of follow up: } 6 \text { months }\end{array}$} \\
\hline Participants & \multicolumn{2}{|c|}{$\begin{array}{l}\text { Orthopaedic hospital, Heidelberg, Germany } \\
80 \text { people with an unstable trochanteric proximal femoral fracture } \\
\text { Age: mean } 83 \text { years } \\
\% \text { male: } 14 \% \\
\text { Number lost to follow up: } 1(1.3 \%) \\
\text { Assigned: } 40 / 40 \text { [Gliding nail / Gamma nail] }\end{array}$} \\
\hline Interventions & \multicolumn{2}{|c|}{$\begin{array}{l}\text { Gliding nail ( } 125 \text { degree) versus a standard ( } 130 \text { degree) Gamma nail. } \\
\text { For the gliding nail, the lag screw of the standard Gamma nail was replaced by a double T profile blade. } \\
\text { All nails were } 220 \mathrm{~mm} \text { long and } 12 \mathrm{~mm} \text { in diameter. A double distal locking was aimed for in all cases. }\end{array}$} \\
\hline Outcomes & \multicolumn{2}{|c|}{$\begin{array}{l}\text { Length of surgery } \\
\text { Operative blood loss } \\
\text { Operative fracture } \\
\text { Cut-out of implant } \\
\text { Later fracture of the femur } \\
\text { Reoperation } \\
\text { Medical complications } \\
\text { Pneumonia } \\
\text { Cerebrovascular accident } \\
\text { Decubitus ulcers } \\
\text { Length of hospital stay } \\
\text { Limb shortening } \\
\text { Rotational deformity } \\
\text { Mortality } \\
\text { Residence } \\
\text { Mobility } \\
\text { Pain } \\
\text { Function: Merle d' Aubigne score }\end{array}$} \\
\hline \multicolumn{3}{|l|}{ Notes } \\
\hline \multicolumn{3}{|l|}{ Risk of bias } \\
\hline Item & Authors' judgement & Description \\
\hline Allocation concealment? & Unclear & B - Unclear \\
\hline
\end{tabular}

Hardy 2003

\begin{tabular}{l|l}
\hline Methods & $\begin{array}{l}\text { Randomised trial: method not stated } \\
\text { Length of follow up: mean } 37 \text { months (range } 12 \text { to } 49 \text { months) }\end{array}$ \\
\hline Participants & $\begin{array}{l}\text { Orthopaedic hospital, Brussels, Belgium } \\
81 \text { people with an unstable trochanteric proximal femoral fracture (fracture types featuring loss of medial } \\
\text { support: Jensen types IV and V; or reversed oblique fracture lines) }\end{array}$ \\
\hline
\end{tabular}


Hardy 2003 (Continued)

\begin{tabular}{ll} 
Age: mean 77 years \\
\% male: $38 \%$ \\
Number lost to follow up: 1 (1.3\%) \\
Assigned: $42 / 39$ [Dynamic / Static locking] \\
\hline Interventions & $\begin{array}{l}\text { Intramedullary hip screw (IMHS) with a slotted hole to allow for dynamic distal locking of the nail with } \\
\text { one screw versus a standard IMHS statically locked with two distal locking screws. } \\
\text { All nails were } 12 \text { mm in diameter, with a 135 degree angle between the nail and lag screw, and } 4 \text { degree } \\
\text { valgus angle. }\end{array}$ \\
\hline Lutcomes & $\begin{array}{l}\text { Length of surgery } \\
\text { Operative blood loss } \\
\text { Haemoglobin level } \\
\text { Volume of blood transfused } \\
\text { Cut-out of implant } \\
\text { Later fracture of the femur } \\
\text { Reoperation } \\
\text { Mortality } \\
\text { Pain } \\
\text { Mobility score } \\
\text { Independence (Jensen's autonomy index) } \\
\text { Limb shortening } \\
\text { Subsidence of the nail } \\
\text { Cortical hypertrophy }\end{array}$ \\
\hline \\
\hline
\end{tabular}

Notes

One patient allocated dynamic locking was excluded because the nail was erroneously locked with two screws.

\section{Risk of bias}

\begin{tabular}{l|l|l}
\hline Item & Authors' judgement & Description \\
\hline Allocation concealment? & Unclear & B - Unclear \\
\hline
\end{tabular}

\section{Herrera 2002}

Methods

Quasi-randomised trial: based on odd and even record numbers

Length of follow up: 12 months minimum

Orthopaedic hospital, Zaragoza, Spain
250 people with a trochanteric proximal femoral fracture: A1, A2 or A3 (stable and unstable). Pathological
fractures included
Age: mean 79 years
\% male: $28 \%$
Number lost to follow up: not stated
Assigned: $125 / 125$ [PFN / Gamma nail]


Herrera 2002 (Continued)

\begin{tabular}{|c|c|}
\hline Interventions & $\begin{array}{l}\text { Proximal femoral nail (PFN): usually } 130 \text { degree, } 10 \mathrm{~mm} \text { (inserted without reaming) versus a Gamma } \\
\text { nail (usually a } 130 \text { degree, } 11 \mathrm{~mm} \text { ) inserted with reaming. } \\
\text { With } 3 \text { exceptions (in the Gamma nail group) nails were locked distally using one or two screws. }\end{array}$ \\
\hline Outcomes & $\begin{array}{l}\text { Length of surgery } \\
\text { Operative blood loss } \\
\text { Blood transfusion } \\
\text { Cut-out of implant } \\
\text { Operative fracture of femur (greater trochanter) } \\
\text { Later fracture of the femur } \\
\text { Secondary varus ( }>10 \%) \\
\text { Breakage of implant } \\
\text { Poor reduction of fracture } \\
\text { Migration of the proximal nail screw(s) } \\
\text { Non-union (and time to healing) } \\
\text { Reoperation } \\
\text { Seroma } \\
\text { Haematoma } \\
\text { Superficial wound infection } \\
\text { Deep wound infection } \\
\text { Length of hospital stay } \\
\text { Pressure sores } \\
\text { Pulmonary embolism } \\
\text { Acute post-operative confusion } \\
\text { Digestive haemorrhage } \\
\text { Acute kidney failure } \\
\text { Muscle pain "due to point effect" } \\
\text { Mortality } \\
\text { Recovery of walking ability }\end{array}$ \\
\hline Notes & Information on method of randomisation received from Dr Herrera $(28 / 09 / 04)$ \\
\hline
\end{tabular}

Risk of bias

\begin{tabular}{l|ll}
\hline Item & Authors' judgement & Description \\
\hline Allocation concealment? & No & C - Inadequate \\
\hline
\end{tabular}

\section{Marques 2005}

\begin{tabular}{ll} 
Methods & $\begin{array}{l}\text { Quasi-randomised trial: based on odd and even record numbers } \\
\text { Length of follow up: } 12 \text { months }\end{array}$ \\
\hline Participants & $\begin{array}{l}\text { Orthopaedic hospital, Barcelona, Spain } \\
156 \text { people with an unstable trochanteric proximal femoral fracture (AO types } 31 \text { A2 and A3) } \\
\text { Age: mean } 82 \text { years } \\
\text { \% male: } 24 \% \\
\text { Number lost to follow up: } 25(16 \%)\end{array}$
\end{tabular}




\section{Marques 2005 (Continued)}

Assigned: 79/77 [PFN / Gamma nail]

\begin{tabular}{ll}
\hline Interventions & Proximal femoral nail (PFN) versus a trochanteric Gamma nail. \\
The PFN was $10 \mathrm{~mm}$ diameter, inserted without reaming, and had two distally locking screws. The \\
Gamma nail was $11 \mathrm{~mm}$ distal diameter, and inserted with reaming and had one distal locking screw. \\
With 3 exceptions (in the Gamma nail group) nails were locked distally using one or two screws.
\end{tabular}

Risk of bias

\begin{tabular}{l|ll}
\hline Item & Authors' judgement & Description \\
\hline Allocation concealment? & No & C - Inadequate \\
\hline
\end{tabular}

\section{Papasimos 2005}

\begin{tabular}{ll} 
Methods & $\begin{array}{l}\text { Randomised trial: method not stated } \\
\text { Length of follow up: mean } 12 \text { months }\end{array}$ \\
\hline Participants & $\begin{array}{l}\text { Orthopaedic hospital, Patras Hellas, Greece } \\
141 \text { people with an unstable trochanteric proximal femoral fracture (see Notes) } \\
\text { Age (of } 80 \text { participants): mean } 81 \text { years } \\
\% \text { male (of } 80): 41 \% \\
\text { Number lost to follow up (of } 141): 11(7.8 \%) \\
\text { Assigned: ?/? [PFN / Gamma nail] } \\
\text { In analyses: } 40 / 40 \text { [PFN / Gamma nail] }\end{array}$
\end{tabular}


Papasimos 2005 (Continued)

\begin{tabular}{|c|c|}
\hline Interventions & $\begin{array}{l}\text { Proximal femoral nail (PFN) versus a trochanteric Gamma nail. } \\
11 \text { or } 12 \mathrm{~mm} \text { diameter PFN with distal locking in } 37 \text { out of } 40 \text { participants. } 135 \text { degree trochanteric } \\
\text { Gamma nail with } 17 \mathrm{~mm} \text { proximal diameter and } 11 \mathrm{~mm} \text { distal diameter and distal locking in all partici- } \\
\text { pants. }\end{array}$ \\
\hline Outcomes & $\begin{array}{l}\text { Length of surgery } \\
\text { Operative blood loss } \\
\text { Radiographic screening time } \\
\text { Operative fracture (some of greater trochanter) } \\
\text { Cut-out of implant } \\
\text { Later fracture of the femur } \\
\text { Non-union } \\
\text { Reoperation } \\
\text { Superficial wound infection } \\
\text { Haematoma } \\
\text { Medical complications } \\
\text { Chest infection } \\
\text { Pneumonia } \\
\text { Mental disturbances } \\
\text { Deep vein thrombosis } \\
\text { Pulmonary embolism } \\
\text { Urinary infection } \\
\text { Length of hospital stay } \\
\text { Time to fracture consolidation } \\
\text { Function: Salvati and Wilson score }\end{array}$ \\
\hline Notes & $\begin{array}{l}\text { There were } 141 \text { people randomised into this trial but the intervention groups for the } 10 \text { participants who } \\
\text { died before one year and the } 11 \text { who were lost to follow up were not identified. Forty of the } 120 \text { participants } \\
\text { included in the trial analyses were treated with a sliding hip screw. The results for this group are included } \\
\text { in the Cochrane review 'Gamma and other cephalocondylic intramedullary nails versus extramedullary } \\
\text { implants for extracapsular hip fractures in adults'. }\end{array}$ \\
\hline
\end{tabular}

Risk of bias

\begin{tabular}{l|ll}
\hline Item & Authors' judgement & Description \\
\hline Allocation concealment? & Unclear & B - Unclear \\
\hline
\end{tabular}

\section{Schipper 2004}

\begin{tabular}{l|l} 
Methods & $\begin{array}{l}\text { Randomised trial: numbered and blinded envelopes with computer generated randomi } \\
\text { Length of follow up: } 4 \text { months for whole trial population; } 12 \text { months for those with } \\
\text { fractures at } 4 \text { months }\end{array}$ \\
\hline Participants & $\begin{array}{l}\text { Multi-centre study conducted in } 9 \text { orthopaedic hospitals, The Netherlands } \\
424 \text { people with an unstable trochanteric proximal femoral fracture. Age } 60 \text { or above } \\
\text { Age: mean } 82 \text { years } \\
\% \text { male: } 18 \%\end{array}$
\end{tabular}




\section{Schipper 2004 (Continued)}

Number lost to follow up: 12 at 4 months $(2.8 \%)$

Assigned: 211/213 [PFN / Gamma nail]

\begin{tabular}{|c|c|}
\hline Interventions & $\begin{array}{l}\text { Proximal femoral nail (PFN) versus a standard ( } 130 \text { degree, } 11 \mathrm{~mm}) \text { mark } 3 \text { Gamma nail. } \\
\text { The PFN was } 130 \text { degree, } 10 \text { or } 11 \mathrm{~mm} \text {, and inserted without reaming. The Gamma nail was inserted } \\
\text { with reaming. } \\
\text { All nails were locked distally in a static mode. }\end{array}$ \\
\hline Outcomes & $\begin{array}{l}\text { Length of surgery } \\
\text { Operative blood loss } \\
\text { Cut-out of implant } \\
\text { Operative fracture of femur } \\
\text { Later fracture of the femur } \\
\text { Technical difficulty during surgery } \\
\text { Breakage of implant } \\
\text { Suboptimal screw position } \\
\text { Malrotation } \\
\text { Need of open reduction } \\
\text { Poor reduction of fracture } \\
\text { Migration of the proximal nail screw(s) } \\
\text { Union (fracture consolidation) } \\
\text { Reoperation } \\
\text { Superficial wound infection } \\
\text { Deep wound infection } \\
\text { Time to full weight bearing } \\
\text { Length of hospital stay } \\
\text { Pressure sores } \\
\text { Pneumonia } \\
\text { Thromboembolic complications } \\
\text { Cardiovascular, urogenital, neurological, gastrointestinal and psychiatric complications } \\
\text { Mortality } \\
\text { Harris Hip Surgery score }\end{array}$ \\
\hline
\end{tabular}

Notes

Follow up of the full trial population was up to 4 months. As per protocol, only those with incomplete radiological consolidation of their fractures at 4 months ( 85 versus 83 ) were followed up until 12 months. Additional clarification on results supplied by trialists.

Risk of bias

\begin{tabular}{l|l} 
Item Authors' judgement & Description
\end{tabular}

Allocation concealment? Yes $\quad$ A - Adequate


Starr 2006

\begin{tabular}{l|l} 
Methods & $\begin{array}{l}\text { Randomised trial: numbered sealed envelopes (some attempt made to obscure allocation but of uncertain } \\
\text { effectiveness) } \\
\text { Length of follow up: minimum } 12 \text { months (range } 12 \text { to } 29 \text { months) }\end{array}$ \\
\hline Participants & $\begin{array}{l}\text { Orthopaedic hospital, Dallas, USA } \\
34 \text { people (aged } 10 \text { to } 50 \text { years) with an extracapsular proximal femoral fracture caused by high energy } \\
\text { trauma (15\% stable trochanteric, } 62 \% \text { unstable trochanteric, } 24 \% \text { subtrochanteric fractures) } \\
\text { Age: mean } 34 \text { years (range } 19 \text { to } 50 \text { years) } \\
\% \text { male: } 35 \% \\
\text { Number lost to follow up: } 6 \text { (18\%) } \\
\text { Assigned: } 17 / 17 \text { [Russell Taylor / long Gamma nail] }\end{array}$ \\
\hline
\end{tabular}

Interventions $\quad$ Russell Taylor Recon or Delta Intramedullary nail versus a long Gamma intramedullary nail.

The Russell Taylor nails were 10-14 mm distal diameter and had two proximal screws. The Gamma nails were $11 \mathrm{~mm}$ distal diameter. All nails were statically locked.

\begin{tabular}{|c|c|c|}
\hline Outcomes & \multicolumn{2}{|l|}{$\begin{array}{l}\text { Length of surgery } \\
\text { Operative blood loss } \\
\text { Cut-out of implant } \\
\text { Operative fracture of the femur } \\
\text { Later fracture of the femur } \\
\text { Non-union } \\
\text { Reoperation } \\
\text { Wound infection } \\
\text { Deep would infection } \\
\text { Mortality } \\
\text { Harris hip score } \\
\text { Mobility } \\
\text { Unable to do the same work } \\
\text { Hip and knee range of movement }\end{array}$} \\
\hline Notes & \multicolumn{2}{|c|}{$\begin{array}{l}\text { Extra information including method of randomisation and fracture distribution was supplied by trialists } \\
\text { Three patients had open fractures and } 17 \text { ( } 9 \text { versus } 8 \text { ) had concurrent surgery for other injuries. }\end{array}$} \\
\hline \multicolumn{3}{|l|}{ Risk of bias } \\
\hline Item & Authors' judgement & Description \\
\hline Allocation concealment? & Unclear & B - Unclear \\
\hline
\end{tabular}

\section{Vidyadhara 2007}

\begin{tabular}{l|l} 
Methods & $\begin{array}{l}\text { Randomised trial: computer generated random numbers table } \\
\text { Length of follow up: } 24 \text { months }\end{array}$ \\
\hline Participants & $\begin{array}{l}\text { Orthopaedic hospital, Karnataka, India } \\
73 \text { people with an unstable trochanteric proximal femoral fracture (AO types 31 A2.2, A2.3, A3.1, A3.2 } \\
\text { and A3.3) }\end{array}$
\end{tabular}


Age: mean 69 years (range 61 to 89 years)

$\%$ male: $51 \%$

Number lost to follow up: none

Assigned: 36/37 [ACE trochanteric nail / AP Gamma nail]

Interventions $\quad$ ACE trochanteric nail versus an AP (Asian/Pacific) Gamma nail.

Nails of 130 degree angle and $200 \mathrm{~mm}$ length used in both groups. Both nails locked distally with the upper screw. The proximal anti-rotation screw was used in all cases of the ACE nail.

\begin{tabular}{|c|c|c|}
\hline Outcomes & $\begin{array}{l}\text { Length of surgery } \\
\text { Operative blood loss } \\
\text { Cut-out of implant } \\
\text { Later fracture of the femur } \\
\text { Non-union } \\
\text { Reoperation } \\
\text { All wound infection } \\
\text { Deep wound infection } \\
\text { Deep vein thrombosis } \\
\text { Shortening } \\
\text { Pain (at } 1 \text { month) } \\
\text { Mortality } \\
\text { Harris hip score } \\
\text { Mobility } \\
\text { Limp } \\
\text { Difficulty in squatting }\end{array}$ & \\
\hline Notes & Extra information, includin & deaths, supplied by trialists \\
\hline Risk of bias & & \\
\hline Item & Authors' judgement & Description \\
\hline Allocation concealment? & Unclear & B - Unclear \\
\hline
\end{tabular}

PFN: proximal femoral nail

\section{Characteristics of excluded studies [ordered by study ID]}

Merenyi 1995 This conference abstract suggested a randomised trial comparing three "different types of Gamma nail” versus Ender nails versus angle plates. Previous correspondence with the authors indicated there was no randomisation of patients only a 'random' selection of patients which had been previously treated with one of the different types of implant. 
(Continued)

Suckel 2006 This was a comparative study of 240 patients with extra-articular femur fractures: 124 were treated with a proximal femoral nail and 116 with a gliding nail. The study was excluded as there was no randomisation of patients.

Wagner 1998 Translation from German of the methods of this comparative study of the intramedullary hip screw with the Gamma nail established that it was not a randomised trial.

\section{Characteristics of studies awaiting assessment [ordered by study ID]}

\section{Gahr 2003}

\begin{tabular}{ll}
\hline Methods & Quasi-randomised trial: alternation \\
\hline Participants & 50 participants with a proximal femoral fracture \\
\hline Interventions & Long Gamma nail $10 \mathrm{~mm}$ diameter versus long Gamma nail $11 \mathrm{~mm}$ diameter \\
\hline Outcomes & X-ray time; length of surgery; need for reaming femur; fixation complications: one cut-out in the $10 \mathrm{~mm}$ group \\
\hline Notes & $\begin{array}{l}\text { Trial report in German with English abstract for outcomes until hospital discharge (mean } 19 \text { days). Follow up is } \\
\text { incomplete but no further report identified. No response from contact author (latest: March 2006). }\end{array}$
\end{tabular}


DATA AND ANALYSES

\section{Comparison 1. Proximal femoral nail (PFN) versus Gamma nail}

\begin{tabular}{|c|c|c|c|c|}
\hline Outcome or subgroup title & $\begin{array}{l}\text { No. of } \\
\text { studies }\end{array}$ & $\begin{array}{c}\text { No. of } \\
\text { participants }\end{array}$ & Statistical method & Effect size \\
\hline $\begin{array}{l}1 \text { Operative details: length of } \\
\text { surgery and blood loss }\end{array}$ & 1 & & Mean Difference (IV, Fixed, 95\% CI) & Totals not selected \\
\hline $\begin{array}{l}1.1 \text { Length of surgery } \\
\text { (minutes) }\end{array}$ & 1 & & Mean Difference (IV, Fixed, 95\% CI) & Not estimable \\
\hline 1.2 Blood loss (ml) & 1 & & Mean Difference (IV, Fixed, 95\% CI) & Not estimable \\
\hline 2 Number of patients transfused & 2 & & Risk Ratio (M-H, Random, 95\% CI) & Totals not selected \\
\hline 3 Intra-operative complications & 4 & & Risk Ratio (M-H, Fixed, 95\% CI) & Subtotals only \\
\hline $\begin{array}{l}3.1 \text { Changed method of } \\
\text { fixation }\end{array}$ & 1 & 424 & Risk Ratio (M-H, Fixed, 95\% CI) & $0.76[0.17,3.34]$ \\
\hline 3.2 Open reduction & 1 & 424 & Risk Ratio (M-H, Fixed, 95\% CI) & $2.15[0.95,4.86]$ \\
\hline 3.3 Poor reduction & 2 & 504 & Risk Ratio (M-H, Fixed, 95\% CI) & $2.01[0.62,6.57]$ \\
\hline 3.4 Difficult surgery & 2 & 504 & Risk Ratio (M-H, Fixed, 95\% CI) & $1.46[0.98,2.19]$ \\
\hline $\begin{array}{l}\text { 3.5 Difficult proximal or distal } \\
\text { screw insertion }\end{array}$ & 1 & 424 & Risk Ratio (M-H, Fixed, 95\% CI) & $1.01[0.36,2.83]$ \\
\hline $\begin{array}{l}\text { 3.6 Intra-operative } \\
\text { comminution of the fracture } \\
\text { around the trochanteric region }\end{array}$ & 2 & 330 & Risk Ratio (M-H, Fixed, 95\% CI) & $0.3[0.12,0.73]$ \\
\hline $\begin{array}{l}3.7 \text { Operative fracture of the } \\
\text { femur }\end{array}$ & 4 & 910 & Risk Ratio (M-H, Fixed, 95\% CI) & $0.33[0.07,1.63]$ \\
\hline $\begin{array}{l}3.8 \text { Suboptimal position of } \\
\text { fixation devices }\end{array}$ & 1 & 424 & Risk Ratio (M-H, Fixed, 95\% CI) & $1.23[0.77,1.95]$ \\
\hline 4 Fracture healing complications & 4 & & Risk Ratio (M-H, Fixed, 95\% CI) & Subtotals only \\
\hline 4.1 Cut-out & 4 & 910 & Risk Ratio (M-H, Fixed, 95\% CI) & $0.71[0.39,1.30]$ \\
\hline 4.2 Later fracture of femur & 4 & 910 & Risk Ratio (M-H, Fixed, 95\% CI) & $0.82[0.24,2.84]$ \\
\hline 4.3 Implant breakage & 3 & 754 & Risk Ratio (M-H, Fixed, 95\% CI) & $0.34[0.01,8.21]$ \\
\hline $\begin{array}{l}4.4 \text { Non-union/ } \\
\text { pseudoarthrosis }\end{array}$ & 3 & 754 & Risk Ratio (M-H, Fixed, 95\% CI) & $0.60[0.14,2.50]$ \\
\hline 4.5 Secondary varus $(>10 \%)$ & 1 & 250 & Risk Ratio (M-H, Fixed, 95\% CI) & $4.5[0.99,20.41]$ \\
\hline $\begin{array}{l}\text { 4.6 Fracture site collapse due } \\
\text { to screw migration }\end{array}$ & 1 & 250 & Risk Ratio (M-H, Fixed, 95\% CI) & $2.5[0.81,7.76]$ \\
\hline $\begin{array}{l}4.7 \text { Medial or lateral hip screw } \\
\text { migration }\end{array}$ & 1 & 424 & Risk Ratio (M-H, Fixed, 95\% CI) & $6.06[1.37,26.74]$ \\
\hline $\begin{array}{l}\text { 4.8 Muscle pain due to 'point } \\
\text { effect' }\end{array}$ & 1 & 250 & Risk Ratio (M-H, Fixed, 95\% CI) & $0.57[0.17,1.90]$ \\
\hline 5 Reoperation & 4 & 910 & Risk Ratio (M-H, Fixed, 95\% CI) & $1.25[0.83,1.90]$ \\
\hline 6 Wound complications & 4 & & Risk Ratio (M-H, Fixed, 95\% CI) & Subtotals only \\
\hline 6.1 Seroma & 1 & 250 & Risk Ratio (M-H, Fixed, 95\% CI) & $0.90[0.51,1.60]$ \\
\hline 6.2 Haematoma & 4 & 910 & Risk Ratio (M-H, Fixed, 95\% CI) & $0.97[0.62,1.51]$ \\
\hline 6.3 Superficial infection & 3 & 754 & Risk Ratio (M-H, Fixed, 95\% CI) & $0.65[0.32,1.29]$ \\
\hline 6.4 Deep infection & 3 & 830 & Risk Ratio (M-H, Fixed, 95\% CI) & $1.01[0.34,2.95]$ \\
\hline 7 Post-operative complications & 3 & & Risk Ratio (M-H, Fixed, 95\% CI) & Subtotals only \\
\hline 7.1 Pneumonia & 2 & 236 & Risk Ratio (M-H, Fixed, 95\% CI) & $2.93[0.12,70.72]$ \\
\hline 7.2 Pressure sores & 2 & 406 & Risk Ratio (M-H, Fixed, 95\% CI) & $1.08[0.51,2.30]$ \\
\hline
\end{tabular}


7.3 Deep vein thrombosis

7.4 Pulmonary embolism

7.5 Acute post-operative

mental confusion

7.6 Urinary infection

7.7 Digestive haemorrhage

7.8 Acute kidney failure

8 Length of hospital stay (days)

9 Mortality

9.1 At 4 months

9.2 At 12 months

10 Final functional outcomes

10.1 Pain at follow up

10.2 Symptoms or restriction

from the hip

10.3 Incomplete recovery

of walking ability (including

death)

11 Harris hip scores (0 to 100: high values $=$ best function)

11.1 At 4 weeks

11.2 At 4 months

11.3 At 1 year
Risk Ratio (M-H, Fixed, 95\% CI) Risk Ratio (M-H, Fixed, 95\% CI) Risk Ratio (M-H, Fixed, 95\% CI)

Risk Ratio (M-H, Fixed, 95\% CI) Risk Ratio (M-H, Fixed, 95\% CI) Risk Ratio (M-H, Fixed, 95\% CI) Mean Difference (IV, Fixed, 95\% CI) Risk Ratio (M-H, Fixed, 95\% CI) Risk Ratio (M-H, Fixed, 95\% CI) Risk Ratio (M-H, Fixed, 95\% CI) Risk Ratio (M-H, Fixed, 95\% CI) Risk Ratio (M-H, Fixed, 95\% CI) Risk Ratio (M-H, Fixed, 95\% CI)

Risk Ratio (M-H, Fixed, 95\% CI)

Mean Difference (IV, Fixed, 95\% CI)

Mean Difference (IV, Fixed, 95\% CI) Mean Difference (IV, Fixed, 95\% CI) Mean Difference (IV, Fixed, 95\% CI)
$1.65[0.22,12.29]$

$1.5[0.25,8.85]$

$0.78[0.44,1.39]$

$1.13[0.44,2.84]$ $0.33[0.01,8.10]$ $0.5[0.05,5.44]$

Totals not selected Subtotals only $1.27[0.82,1.96]$ $1.08[0.82,1.41]$

Totals not selected Not estimable

Not estimable

Not estimable

Totals not selected

Not estimable

Not estimable Not estimable

\section{Comparison 2. ACE trochanteric nail versus Gamma nail}

\begin{tabular}{|c|c|c|c|c|}
\hline Outcome or subgroup title & $\begin{array}{l}\text { No. of } \\
\text { studies }\end{array}$ & $\begin{array}{c}\text { No. of } \\
\text { participants }\end{array}$ & Statistical method & Effect size \\
\hline $\begin{array}{l}1 \text { Operative details: length } \\
\text { of surgery, blood loss and } \\
\text { radiographic screening time }\end{array}$ & 2 & & Mean Difference (IV, Fixed, 95\% CI) & Totals not selected \\
\hline $\begin{array}{l}1.1 \text { Length of surgery } \\
\text { (minutes) }\end{array}$ & 1 & & Mean Difference (IV, Fixed, 95\% CI) & Not estimable \\
\hline 1.2 Operative blood loss ( $\mathrm{mls})$ & 1 & & Mean Difference (IV, Fixed, 95\% CI) & Not estimable \\
\hline 1.3 Units of blood transfused & 1 & & Mean Difference (IV, Fixed, 95\% CI) & Not estimable \\
\hline $\begin{array}{l}1.4 \text { Radiographic screening } \\
\text { time (minutes) }\end{array}$ & 1 & & Mean Difference (IV, Fixed, 95\% CI) & Not estimable \\
\hline 2 Number of patients transfused & 1 & & Odds Ratio (M-H, Fixed, 95\% CI) & Totals not selected \\
\hline 3 Fracture healing complications & 2 & & Odds Ratio (M-H, Fixed, 95\% CI) & Subtotals only \\
\hline $\begin{array}{l}3.1 \text { Operative fracture of } \\
\text { femur }\end{array}$ & 2 & 185 & Odds Ratio (M-H, Fixed, 95\% CI) & Not estimable \\
\hline 3.2 Later fracture of femur & 2 & 185 & Odds Ratio (M-H, Fixed, 95\% CI) & Not estimable \\
\hline 3.3 Cut-out & 2 & 185 & Odds Ratio (M-H, Fixed, 95\% CI) & $0.33[0.01,8.45]$ \\
\hline 3.4 Non-union & 2 & 185 & Odds Ratio (M-H, Fixed, 95\% CI) & Not estimable \\
\hline $\begin{array}{l}3.5 \text { All fracture healing } \\
\text { complications }\end{array}$ & 2 & 185 & Odds Ratio (M-H, Fixed, 95\% CI) & $0.33[0.01,8.45]$ \\
\hline 3.6 Reoperation & 2 & 185 & Odds Ratio (M-H, Fixed, 95\% CI) & $0.33[0.01,8.45]$ \\
\hline 4 Wound complications & 2 & & Odds Ratio (M-H, Fixed, 95\% CI) & Subtotals only \\
\hline
\end{tabular}




4.1 All wound infection
4.2 Deep wound infection
5 Post-operative complications
5.1 Deep vein thrombosis
5.2 All medical complications
6 Anatomical restoration
6.1 Shortening ( $1 \mathrm{~cm}$ or more)
7 Mortality
8 Final functional outcomes
8.1 Hip pain at 1 month
8.2 Limp
8.3 Difficulty in squatting
9 Mobility score (0: no difficulties
to 9: most difficulties)
10 Harris hip scores ( 0 to $100:$
high values = best function)
10.1 At 4 months
10.2 At 1 year
10.3 At 2 years

185 Odds Ratio (M-H, Fixed, 95\% CI)

185 Odds Ratio (M-H, Fixed, 95\% CI)

Odds Ratio (M-H, Fixed, 95\% CI)

185 Odds Ratio (M-H, Fixed, 95\% CI)

88 Odds Ratio (M-H, Fixed, 95\% CI)

Odds Ratio (M-H, Fixed, 95\% CI)

Odds Ratio (M-H, Fixed, 95\% CI)

185 Odds Ratio (M-H, Fixed, 95\% CI)

Odds Ratio (M-H, Fixed, 95\% CI)

Odds Ratio (M-H, Fixed, 95\% CI)

Odds Ratio (M-H, Fixed, 95\% CI)

Odds Ratio (M-H, Fixed, 95\% CI)

Mean Difference (IV, Fixed, 95\% CI)

Mean Difference (IV, Fixed, 95\% CI)

Mean Difference (IV, Fixed, 95\% CI)

Mean Difference (IV, Fixed, 95\% CI)

Mean Difference (IV, Fixed, 95\% CI)
$1.36[0.29,6.37]$

Not estimable

Subtotals only

$0.33[0.01,8.21]$

$1.37[0.56,3.36]$

Totals not selected

Not estimable

$1.0[0.14,7.36]$

Totals not selected

Not estimable

Not estimable

Not estimable

Totals not selected

Totals not selected

Not estimable

Not estimable

Not estimable

Comparison 3. Gliding nail versus Gamma nail

\begin{tabular}{|c|c|c|c|c|}
\hline Outcome or subgroup title & $\begin{array}{l}\text { No. of } \\
\text { studies }\end{array}$ & $\begin{array}{c}\text { No. of } \\
\text { participants }\end{array}$ & Statistical method & Effect size \\
\hline 1 Fracture fixation complications & 1 & & Risk Ratio (M-H, Fixed, 95\% CI) & Totals not selected \\
\hline $\begin{array}{l}1.1 \text { Operative fracture of } \\
\text { femur }\end{array}$ & 1 & & Risk Ratio (M-H, Fixed, 95\% CI) & Not estimable \\
\hline 1.2 Later fracture of femur & 1 & & Risk Ratio (M-H, Fixed, 95\% CI) & Not estimable \\
\hline 1.3 Cut-out & 1 & & Risk Ratio (M-H, Fixed, 95\% CI) & Not estimable \\
\hline $\begin{array}{l}1.4 \text { Technical complications } \\
\text { of fixation }\end{array}$ & 1 & & Risk Ratio (M-H, Fixed, 95\% CI) & Not estimable \\
\hline 1.5 Reoperation & 1 & & Risk Ratio (M-H, Fixed, 95\% CI) & Not estimable \\
\hline 2 Post-operative complications & 1 & & Risk Ratio (M-H, Fixed, 95\% CI) & Totals not selected \\
\hline $\begin{array}{l}2.1 \text { Participants with a } \\
\text { complication }\end{array}$ & 1 & & Risk Ratio (M-H, Fixed, 95\% CI) & Not estimable \\
\hline 2.2 Pressure sores (decubitus) & 1 & & Risk Ratio (M-H, Fixed, 95\% CI) & Not estimable \\
\hline 2.3 Pneumonia & 1 & & Risk Ratio (M-H, Fixed, 95\% CI) & Not estimable \\
\hline 2.4 Cerebrovascular accident & 1 & & Risk Ratio (M-H, Fixed, 95\% CI) & Not estimable \\
\hline 2.5 Apoplexy & 1 & & Risk Ratio (M-H, Fixed, 95\% CI) & Not estimable \\
\hline 2.6 Forearm fracture & 1 & & Risk Ratio (M-H, Fixed, 95\% CI) & Not estimable \\
\hline 3 Anatomical deformity & 1 & & Risk Ratio (M-H, Fixed, 95\% CI) & Totals not selected \\
\hline 3.1 Leg shortening $>2 \mathrm{~cm}$ & 1 & & Risk Ratio (M-H, Fixed, 95\% CI) & Not estimable \\
\hline $\begin{array}{l}\text { 3.2 External rotation }>20 \\
\text { degrees }\end{array}$ & 1 & & Risk Ratio (M-H, Fixed, 95\% CI) & Not estimable \\
\hline $\begin{array}{l}3.3 \text { Internal rotation }>20 \\
\text { degrees }\end{array}$ & 1 & & Risk Ratio (M-H, Fixed, 95\% CI) & Not estimable \\
\hline 4 Mortality at 6 months & 1 & & Risk Ratio (M-H, Fixed, 95\% CI) & Totals not selected \\
\hline
\end{tabular}


or death) at 6 months

\begin{tabular}{cccc}
$\begin{array}{c}5.1 \text { Living in an geriatric } \\
\text { institution }\end{array}$ & 1 & Risk Ratio (M-H, Fixed, 95\% CI) & Not estimable \\
$\begin{array}{c}5.2 \text { Unfavourable outcome } \\
\text { (institutionalised or dead) }\end{array}$ & 1 & Risk Ratio (M-H, Fixed, 95\% CI) & Not estimable \\
\hline
\end{tabular}

\section{Comparison 4. Russell-Taylor Recon nail versus long Gamma nail}

\begin{tabular}{|c|c|c|c|c|}
\hline Outcome or subgroup title & $\begin{array}{l}\text { No. of } \\
\text { studies }\end{array}$ & $\begin{array}{c}\text { No. of } \\
\text { participants }\end{array}$ & Statistical method & Effect size \\
\hline $\begin{array}{l}1 \text { Fracture healing and wound } \\
\text { healing complications }\end{array}$ & 1 & & Odds Ratio (M-H, Fixed, 95\% CI) & Totals not selected \\
\hline $\begin{array}{l}1.1 \text { Operative fracture of } \\
\text { femur }\end{array}$ & 1 & & Odds Ratio (M-H, Fixed, 95\% CI) & Not estimable \\
\hline 1.2 Later fracture of femur & 1 & & Odds Ratio (M-H, Fixed, 95\% CI) & Not estimable \\
\hline 1.3 Cut-out & 1 & & Odds Ratio (M-H, Fixed, 95\% CI) & Not estimable \\
\hline 1.4 Non-union & 1 & & Odds Ratio (M-H, Fixed, 95\% CI) & Not estimable \\
\hline $\begin{array}{l}\text { 1.5 All fracture healing } \\
\text { complications }\end{array}$ & 1 & & Odds Ratio (M-H, Fixed, 95\% CI) & Not estimable \\
\hline $\begin{array}{l}1.6 \text { Wound infection (any } \\
\text { type) }\end{array}$ & 1 & & Odds Ratio (M-H, Fixed, 95\% CI) & Not estimable \\
\hline 1.7 Deep wound infection & 1 & & Odds Ratio (M-H, Fixed, 95\% CI) & Not estimable \\
\hline 1.8 Reoperation & 1 & & Odds Ratio (M-H, Fixed, 95\% CI) & Not estimable \\
\hline 2 Final outcome measures & 1 & & Odds Ratio (M-H, Fixed, 95\% CI) & Totals not selected \\
\hline 2.1 Mortality & 1 & & Odds Ratio (M-H, Fixed, 95\% CI) & Not estimable \\
\hline $\begin{array}{l}2.2 \text { Non-independent } \\
\text { ambulator }\end{array}$ & 1 & & Odds Ratio (M-H, Fixed, 95\% CI) & Not estimable \\
\hline $\begin{array}{l}2.3 \text { Unable to do the same } \\
\text { work }\end{array}$ & 1 & & Odds Ratio (M-H, Fixed, 95\% CI) & Not estimable \\
\hline
\end{tabular}

Comparison 5. Dynamic versus static locked intramedullary nail

\begin{tabular}{|c|c|c|c|c|}
\hline Outcome or subgroup title & $\begin{array}{l}\text { No. of } \\
\text { studies }\end{array}$ & $\begin{array}{c}\text { No. of } \\
\text { participants }\end{array}$ & Statistical method & Effect size \\
\hline 1 Operative details & 1 & & Mean Difference (IV, Fixed, 95\% CI) & Totals not selected \\
\hline $\begin{array}{l}1.1 \text { Length of surgery } \\
\text { (minutes) }\end{array}$ & 1 & & Mean Difference (IV, Fixed, 95\% CI) & Not estimable \\
\hline $\begin{array}{l}1.2 \text { Intra-operative blood loss } \\
\text { (minutes) }\end{array}$ & 1 & & Mean Difference (IV, Fixed, 95\% CI) & Not estimable \\
\hline $\begin{array}{l}1.3 \text { Haemoglobin level: } 48 \\
\text { hours post-op }(\mathrm{g} / \mathrm{dL})\end{array}$ & 1 & & Mean Difference (IV, Fixed, 95\% CI) & Not estimable \\
\hline
\end{tabular}




\begin{tabular}{|c|c|c|c|}
\hline $\begin{array}{l}1.4 \text { Transfused packed blood } \\
\text { cells }\end{array}$ & 1 & Mean Difference (IV, Fixed, 95\% CI) & Not estimable \\
\hline Fracture fixation complications & 1 & Risk Ratio (M-H, Fixed, 95\% CI) & Totals not selected \\
\hline 2.1 Later fracture of the femur & 1 & Risk Ratio (M-H, Fixed, 95\% CI) & Not estimable \\
\hline 2.2 Cut-out & 1 & Risk Ratio (M-H, Fixed, 95\% CI) & Not estimable \\
\hline $\begin{array}{l}2.3 \text { Technical complications } \\
\text { of fixation }\end{array}$ & 1 & Risk Ratio (M-H, Fixed, 95\% CI) & Not estimable \\
\hline 2.4 Reoperation & 1 & Risk Ratio (M-H, Fixed, 95\% CI) & Not estimable \\
\hline $\begin{array}{l}\text { Leg shortening }(\mathrm{mm}) \text { in those } \\
\text { able to undergo a radiographic } \\
\text { assessment }\end{array}$ & 1 & Mean Difference (IV, Fixed, 95\% CI) & Totals not selected \\
\hline Mortality at 1 year & 1 & Risk Ratio (M-H, Fixed, 95\% CI) & Totals not selected \\
\hline Pain and cortical hypertrophy & 1 & Risk Ratio (M-H, Fixed, 95\% CI) & Totals not selected \\
\hline 5.1 Mid-thigh pain & 1 & Risk Ratio (M-H, Fixed, 95\% CI) & Not estimable \\
\hline 5.2 Cortical hypertrophy & 1 & Risk Ratio (M-H, Fixed, 95\% CI) & Not estimable \\
\hline
\end{tabular}

\section{Analysis I.I. Comparison I Proximal femoral nail (PFN) versus Gamma nail, Outcome I Operative details: length of surgery and blood loss.}

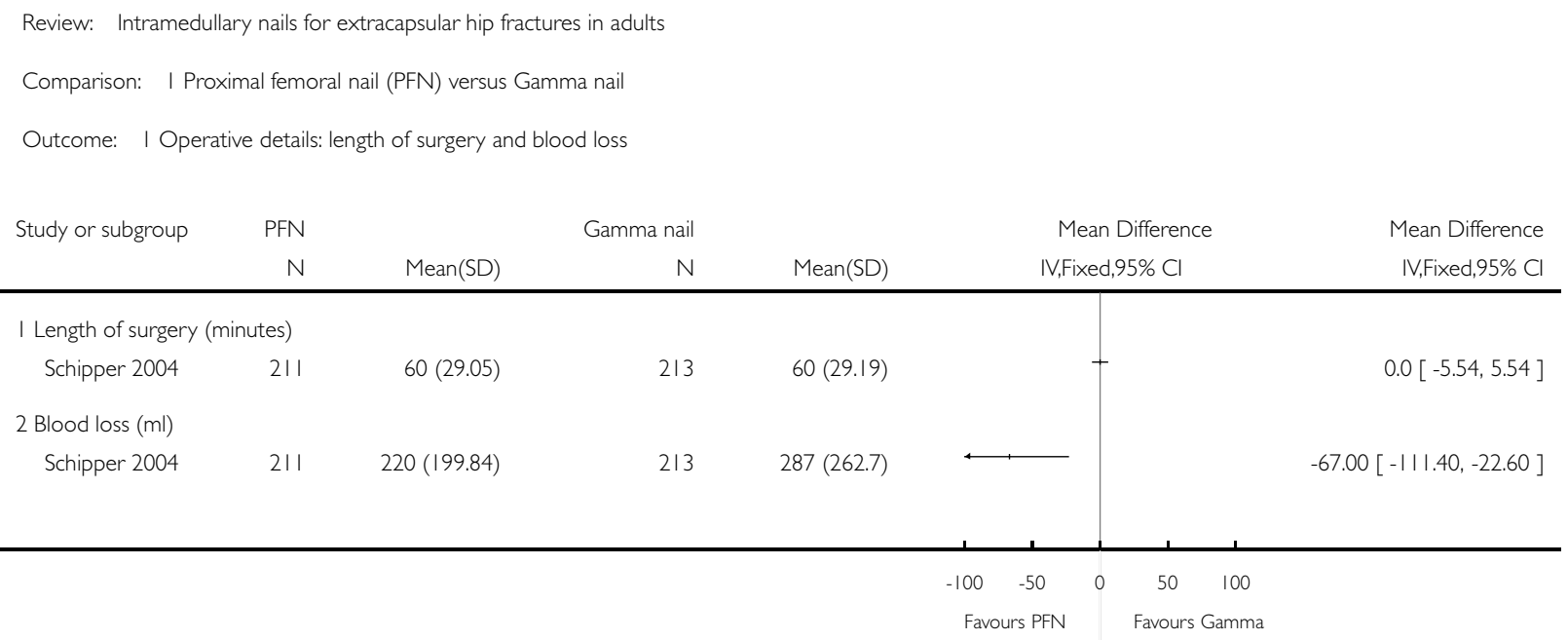


Analysis I.2. Comparison I Proximal femoral nail (PFN) versus Gamma nail, Outcome 2 Number of patients transfused.

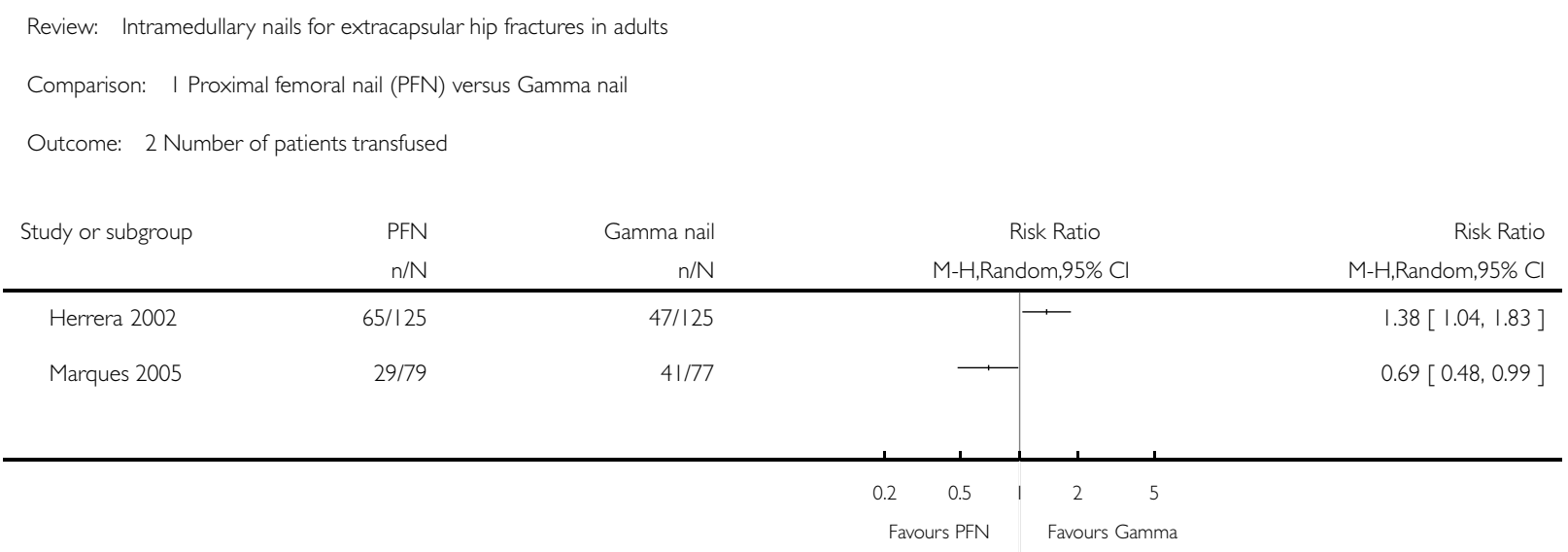

Analysis I.3. Comparison I Proximal femoral nail (PFN) versus Gamma nail, Outcome 3 Intra-operative complications.

Review: Intramedullary nails for extracapsular hip fractures in adults

Comparison: I Proximal femoral nail (PFN) versus Gamma nail

Outcome: 3 Intra-operative complications

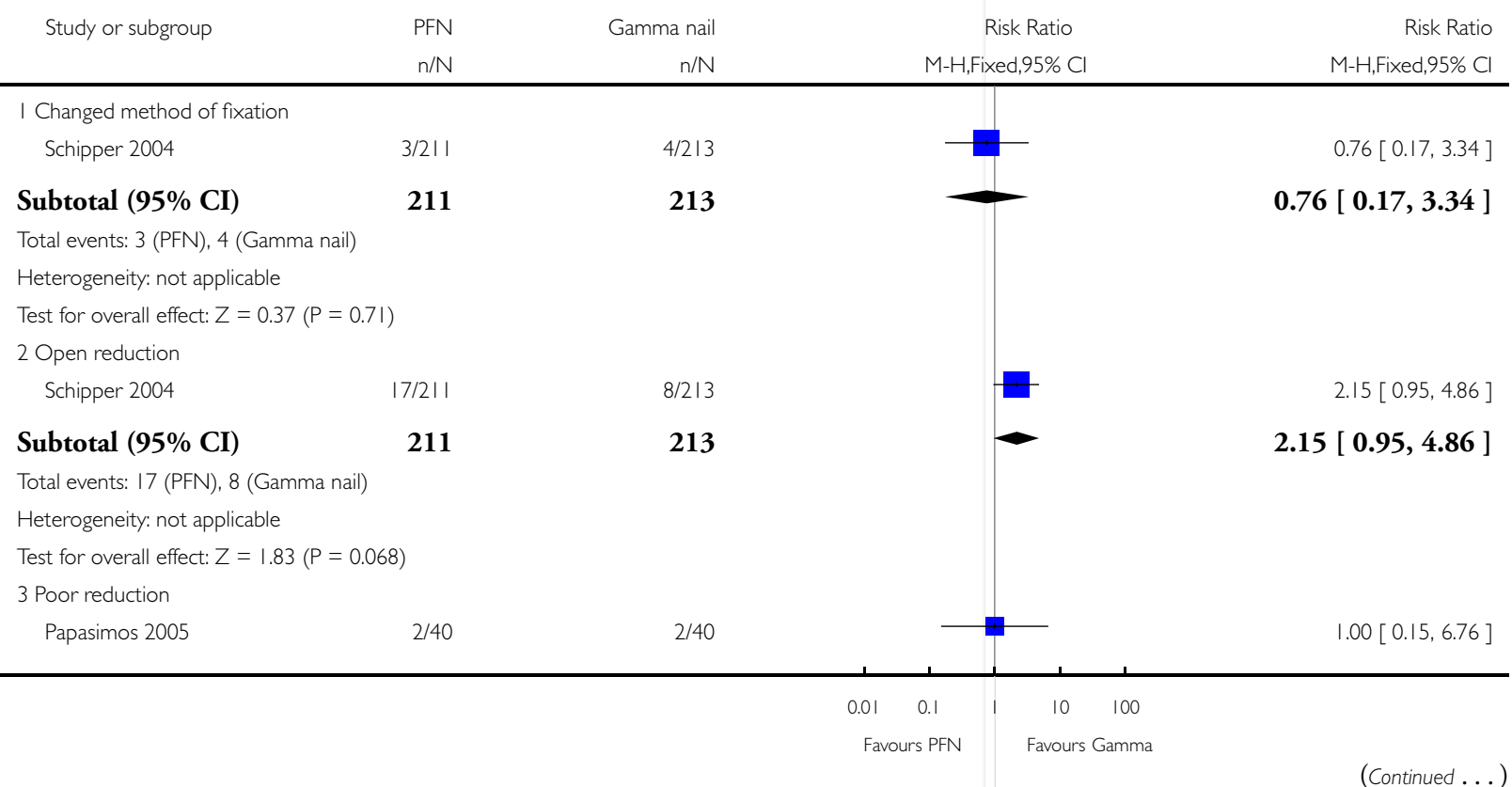




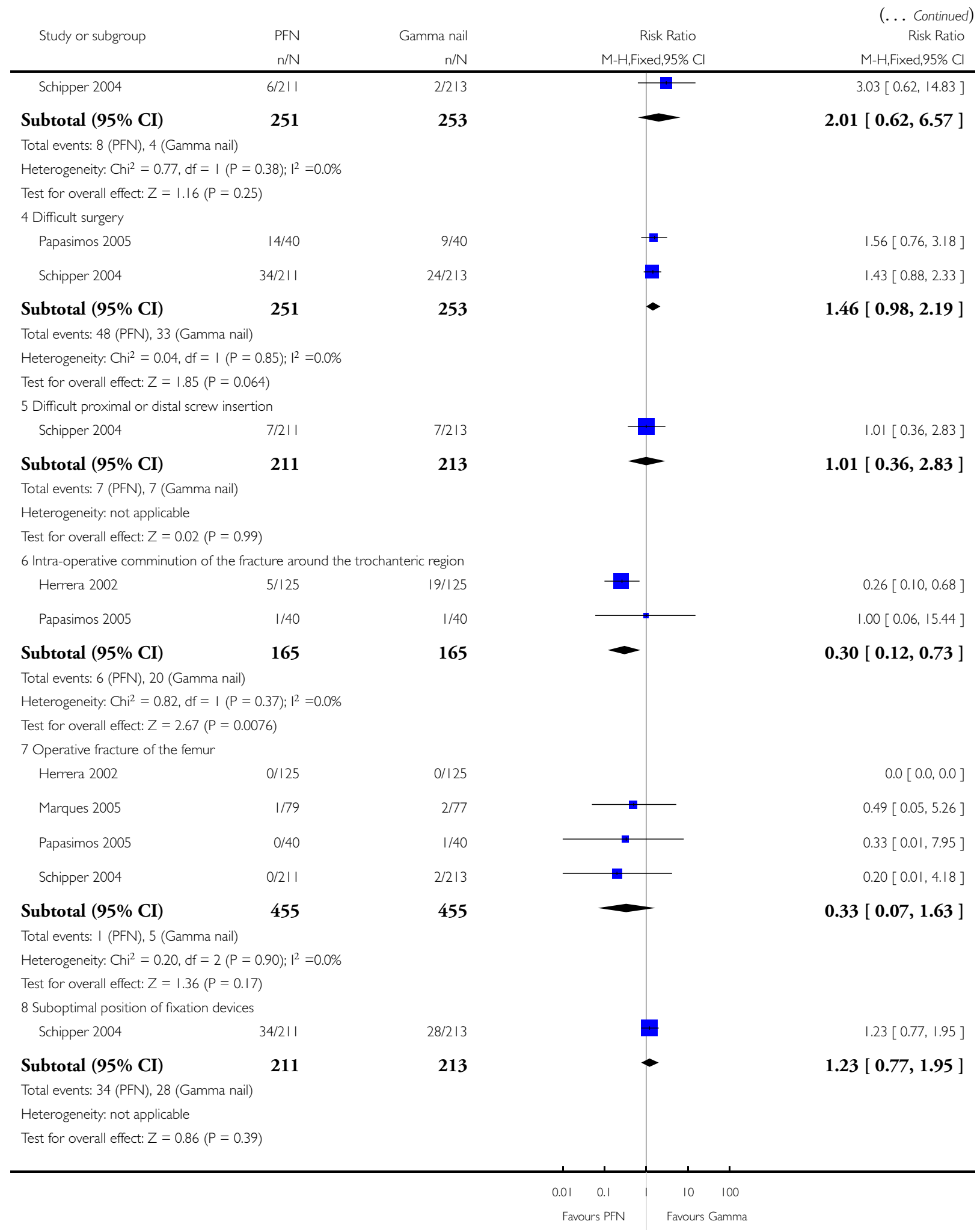


Analysis I.4. Comparison I Proximal femoral nail (PFN) versus Gamma nail, Outcome 4 Fracture healing complications.

Review: Intramedullary nails for extracapsular hip fractures in adults

Comparison: I Proximal femoral nail (PFN) versus Gamma nail

Outcome: 4 Fracture healing complications

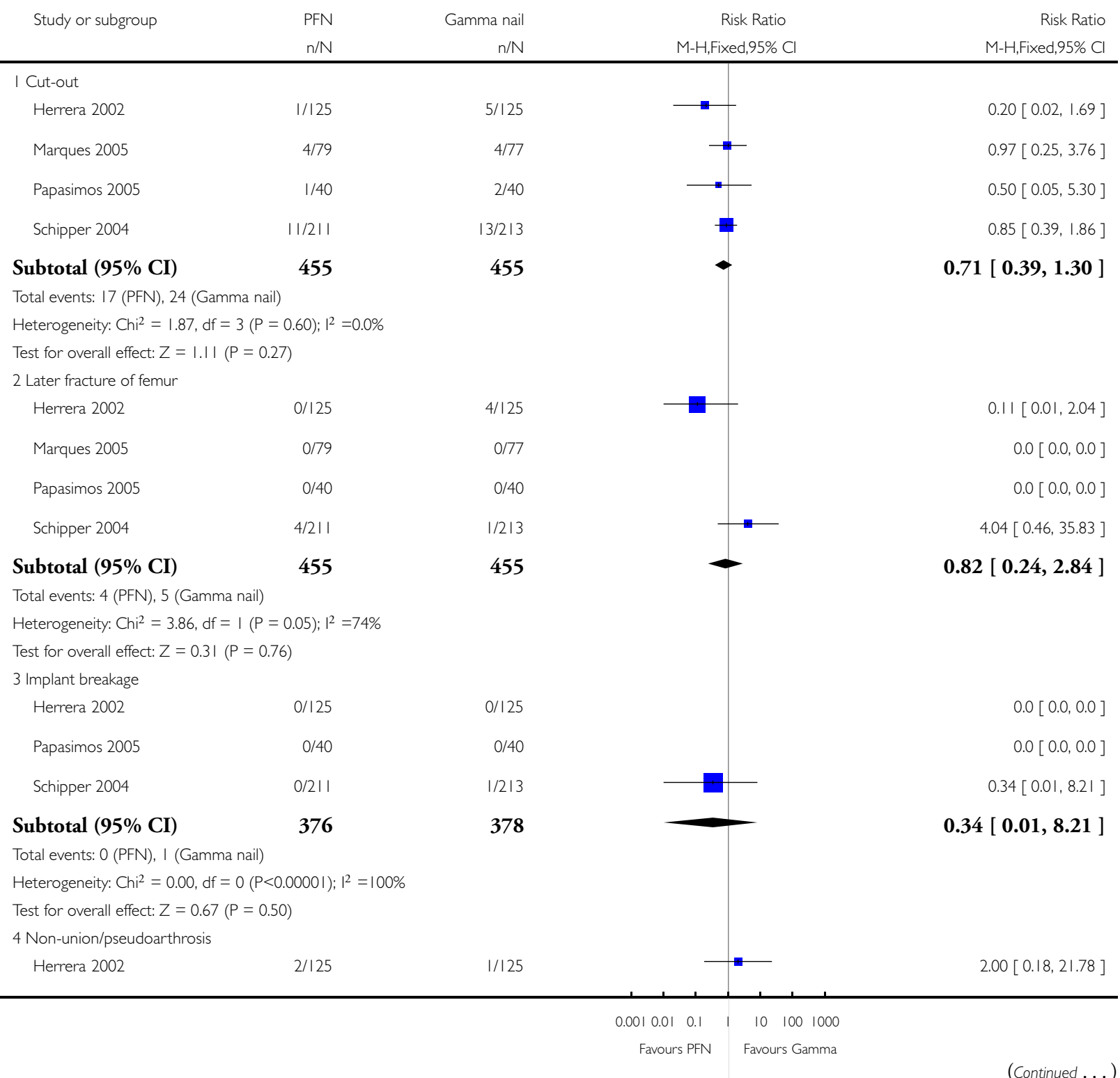




\begin{tabular}{|c|c|c|c|c|}
\hline Study or subgroup & $\begin{array}{l}\text { PFN } \\
n / N\end{array}$ & Gamma nail & $\begin{array}{c}\text { Risk Ratio } \\
\text { M-H.Fixed,95\% Cl }\end{array}$ & $\begin{array}{c}\text { (. . . Continued) } \\
\text { Risk Ratio } \\
\text { M-H,Fixed,95\% Cl }\end{array}$ \\
\hline Papasimos 2005 & $0 / 40$ & $1 / 40$ & $\Longrightarrow$ & $0.33[0.01,7.95]$ \\
\hline Schipper 2004 & $0 / 211$ & $2 / 213$ & $\square$ & $0.20[0.01,4.18]$ \\
\hline Subtotal $(95 \% \mathrm{CI})$ & 376 & 378 & & $0.60[0.14,2.50]$ \\
\hline \multicolumn{5}{|c|}{ Total events: 2 (PFN), 4 (Gamma nail) } \\
\hline \multicolumn{5}{|c|}{ Heterogeneity: $\mathrm{Chi}^{2}=1.60, \mathrm{df}=2(\mathrm{P}=0.45) ; \mathrm{I}^{2}=0.0 \%$} \\
\hline \multicolumn{5}{|c|}{ Test for overall effect: $Z=0.70(P=0.49)$} \\
\hline \multicolumn{5}{|l|}{5 Secondary varus $(>10 \%)$} \\
\hline Herrera 2002 & $9 / 125$ & $2 / 125$ & & $4.50[0.99,20.41]$ \\
\hline Subtotal $(95 \% \mathrm{CI})$ & 125 & 125 & - & $4.50[0.99,20.41]$ \\
\hline \multicolumn{5}{|c|}{ Total events: 9 (PFN), 2 (Gamma nail) } \\
\hline \multicolumn{5}{|c|}{ Heterogeneity: not applicable } \\
\hline \multicolumn{5}{|c|}{ Test for overall effect: $Z=1.95(P=0.05 \mathrm{I})$} \\
\hline \multicolumn{5}{|c|}{6 Fracture site collapse due to screw migration } \\
\hline Herrera 2002 & $10 / 125$ & $4 / 125$ & & $2.50[0.81,7.76]$ \\
\hline Subtotal $(95 \% \mathrm{CI})$ & 125 & 125 & 一 & $2.50[0.81,7.76]$ \\
\hline \multicolumn{5}{|c|}{ Total events: 10 (PFN), 4 (Gamma nail) } \\
\hline \multicolumn{5}{|c|}{ Heterogeneity: not applicable } \\
\hline \multicolumn{5}{|c|}{ Test for overall effect: $Z=1.59(P=0.11)$} \\
\hline \multicolumn{5}{|c|}{7 Medial or lateral hip screw migration } \\
\hline Schipper 2004 & $12 / 211$ & $2 / 213$ & - & $6.06[1.37,26.74]$ \\
\hline Subtotal $(95 \% \mathrm{CI})$ & 211 & 213 & - & $6.06[1.37,26.74]$ \\
\hline \multicolumn{5}{|c|}{ Total events: 12 (PFN), 2 (Gamma nail) } \\
\hline \multicolumn{5}{|c|}{ Heterogeneity: not applicable } \\
\hline \multicolumn{5}{|c|}{ Test for overall effect: $Z=2.38(P=0.017)$} \\
\hline \multicolumn{5}{|c|}{8 Muscle pain due to 'point effect' } \\
\hline Herrera 2002 & $4 / 125$ & $7 / 125$ & & $0.57[0.17,1.90]$ \\
\hline Subtotal (95\% CI) & 125 & 125 & & $0.57[0.17,1.90]$ \\
\hline \multicolumn{5}{|c|}{ Total events: 4 (PFN), 7 (Gamma nail) } \\
\hline \multicolumn{5}{|c|}{ Heterogeneity: not applicable } \\
\hline \multicolumn{5}{|c|}{ Test for overall effect: $Z=0.91 \quad(P=0.36)$} \\
\hline
\end{tabular}


Analysis I.5. Comparison I Proximal femoral nail (PFN) versus Gamma nail, Outcome 5 Reoperation. Review: Intramedullary nails for extracapsular hip fractures in adults

Comparison: I Proximal femoral nail (PFN) versus Gamma nail

Outcome: 5 Reoperation

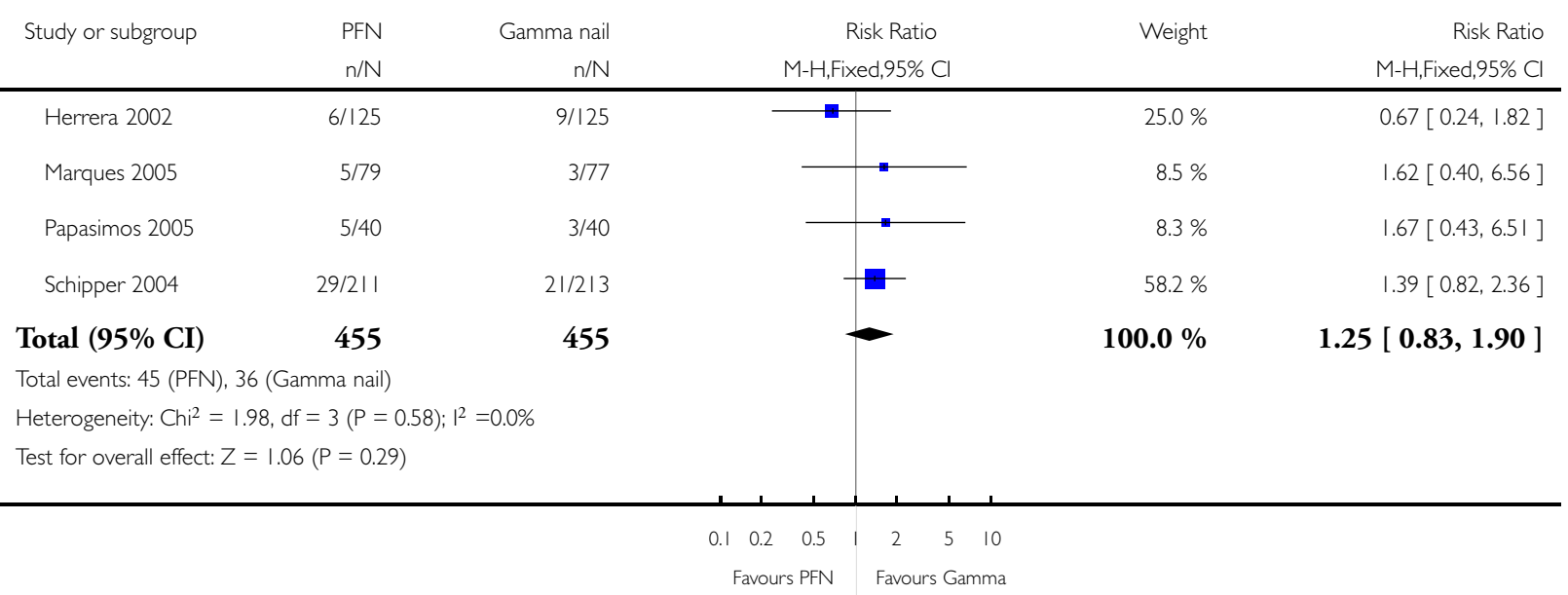


Analysis I.6. Comparison I Proximal femoral nail (PFN) versus Gamma nail, Outcome 6 Wound complications.

Review: Intramedullary nails for extracapsular hip fractures in adults

Comparison: I Proximal femoral nail (PFN) versus Gamma nail

Outcome: 6 Wound complications

\begin{tabular}{|c|c|c|c|c|}
\hline Study or subgroup & $\begin{array}{l}\mathrm{PFN} \\
\mathrm{n} / \mathrm{N}\end{array}$ & $\begin{array}{r}\text { Gamma nail } \\
\mathrm{n} / \mathrm{N}\end{array}$ & $\begin{array}{c}\text { Risk Ratio } \\
\text { M-H,Fixed,95\% Cl }\end{array}$ & $\begin{array}{r}\text { Risk Ratio } \\
\text { M-H,Fixed,95\% Cl }\end{array}$ \\
\hline \multicolumn{5}{|l|}{ I Seroma } \\
\hline Herrera 2002 & $19 / 125$ & $21 / 125$ & & $0.90[0.51,1.60]$ \\
\hline Subtotal (95\% CI) & 125 & 125 & & $0.90[0.51,1.60]$ \\
\hline \multicolumn{5}{|c|}{ Total events: 19 (PFN), 21 (Gamma nail) } \\
\hline \multicolumn{5}{|c|}{ Heterogeneity: not applicable } \\
\hline \multicolumn{5}{|c|}{ Test for overall effect: $Z=0.34(P=0.73)$} \\
\hline \multicolumn{5}{|l|}{2 Haematoma } \\
\hline Herrera 2002 & $17 / 125$ & $13 / 125$ & & $1.31[0.66,2.58]$ \\
\hline Marques 2005 & $8 / 79$ & $1 \mid / 77$ & & $0.71[0.30,1.67]$ \\
\hline Papasimos 2005 & $3 / 40$ & $2 / 40$ & & $1.50[0.26,8.50]$ \\
\hline Schipper 2004 & $7 / 211$ & $10 / 213$ & $\rightarrow$ & $0.71[0.27,1.82]$ \\
\hline Subtotal (95\% CI) & 455 & 455 & & $0.97[0.62,1.51]$ \\
\hline \multicolumn{5}{|c|}{ Total events: 35 (PFN), 36 (Gamma nail) } \\
\hline \multicolumn{5}{|c|}{ Heterogeneity: Chi $^{2}=1.94, d f=3(P=0.59) ;\left.\right|^{2}=0.0 \%$} \\
\hline \multicolumn{5}{|c|}{ Test for overall effect: $Z=0.15(P=0.88)$} \\
\hline \multicolumn{5}{|l|}{3 Superficial infection } \\
\hline Herrera 2002 & $3 / 125$ & $4 / 125$ & 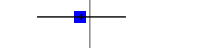 & $0.75[0.17,3.28]$ \\
\hline Papasimos 2005 & $1 / 40$ & $0 / 40$ & & $3.00[0.13,71.51]$ \\
\hline Schipper 2004 & $8 / 211$ & $15 / 213$ & & $0.54[0.23,1.24]$ \\
\hline Subtotal (95\% CI) & 376 & 378 & & $0.65[0.32,1.29]$ \\
\hline \multicolumn{5}{|c|}{ Total events: 12 (PFN), 19 (Gamma nail) } \\
\hline \multicolumn{5}{|c|}{ Heterogeneity: Chi $^{2}=1.12, \mathrm{df}=2(P=0.57) ;\left.\right|^{2}=0.0 \%$} \\
\hline \multicolumn{5}{|c|}{ Test for overall effect: $Z=1.24(P=0.22)$} \\
\hline \multicolumn{5}{|l|}{4 Deep infection } \\
\hline Herrera 2002 & $1 / / 25$ & $0 / 125$ & & $3.00[0.12,72.94]$ \\
\hline Marques 2005 & $0 / 79$ & $0 / 77$ & & $0.0[0.0,0.0]$ \\
\hline Schipper 2004 & $5 / 211$ & $6 / 213$ & & $0.84[0.26,2.71]$ \\
\hline
\end{tabular}

Subtotal (95\% CI)

415

415

$1.01[0.34,2.95$ ]

Total events: 6 (PFN), 6 (Gamma nail)

Heterogeneity: $\mathrm{Chi}^{2}=0.54, \mathrm{df}=\mathrm{I}(\mathrm{P}=0.46) ; \mathrm{I}^{2}=0.0 \%$

Test for overall effect: $Z=0.01(P=0.99)$ 
Analysis I.7. Comparison I Proximal femoral nail (PFN) versus Gamma nail, Outcome 7 Post-operative complications.

Review: Intramedullary nails for extracapsular hip fractures in adults

Comparison: I Proximal femoral nail (PFN) versus Gamma nail

Outcome: 7 Post-operative complications

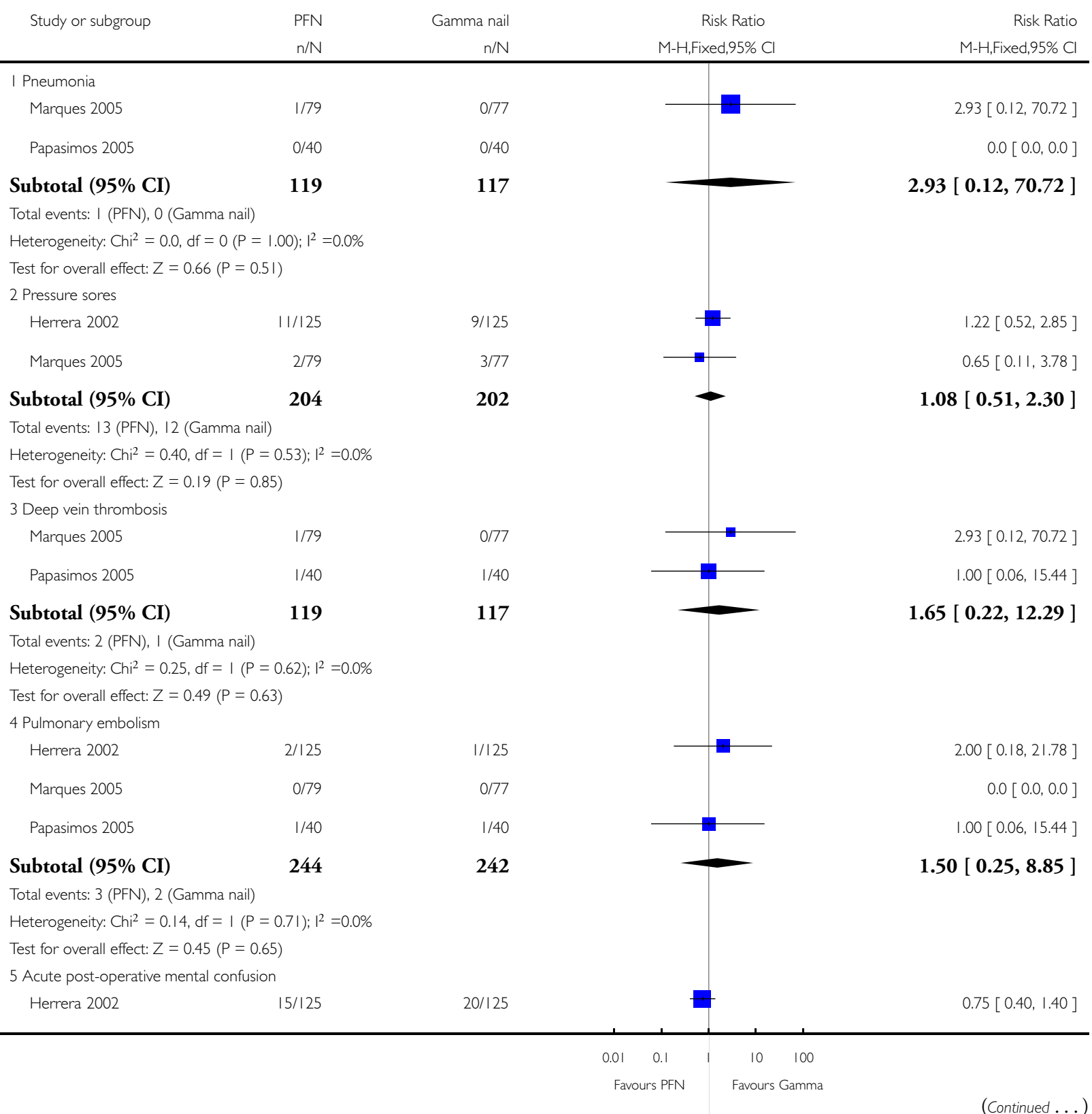




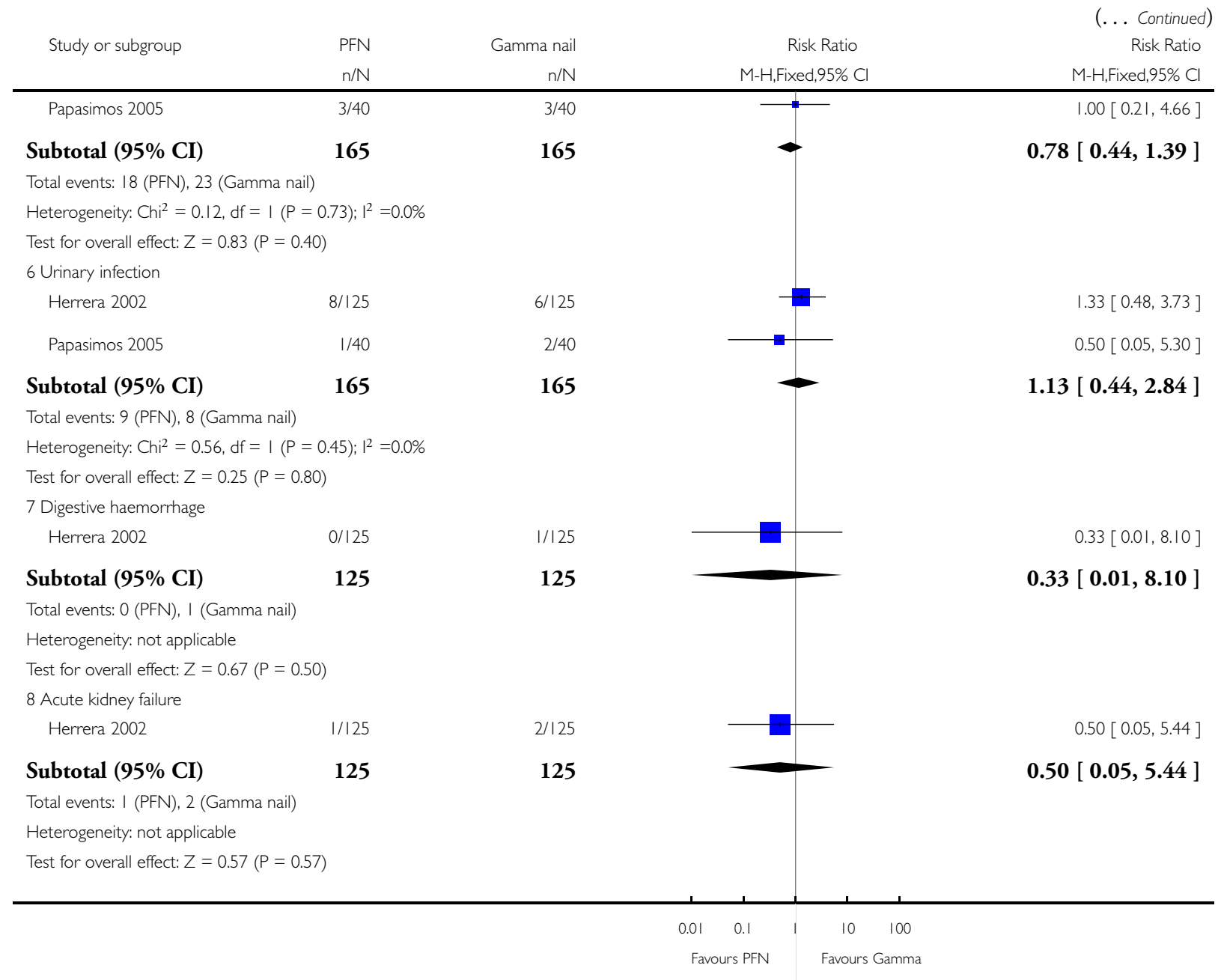

\section{Analysis I.8. Comparison I Proximal femoral nail (PFN) versus Gamma nail, Outcome 8 Length of hospital} stay (days).

Review: Intramedullary nails for extracapsular hip fractures in adults

Comparison: I Proximal femoral nail (PFN) versus Gamma nail

Outcome: 8 Length of hospital stay (days)

\begin{tabular}{|c|c|c|c|c|c|c|c|c|c|}
\hline \multirow[t]{2}{*}{ Study or subgroup } & \multirow{2}{*}{$\begin{array}{r}\text { PFN } \\
\mathrm{N}\end{array}$} & \multicolumn{3}{|c|}{ Gamma } & \multicolumn{4}{|c|}{ Mean Difference } & \multirow{2}{*}{$\begin{array}{r}\text { Mean Difference } \\
\text { IV,Fixed,95\% Cl }\end{array}$} \\
\hline & & Mean(SD) & N & Mean(SD) & & $|\mathrm{V}, \mathrm{Fi}\rangle$ & ed,95\% Cl & & \\
\hline \multirow[t]{3}{*}{ Schipper 2004} & 211 & $21.7(20.34)$ & 213 & $19(17.51)$ & & & - & & $2.70[-0.91,6.31]$ \\
\hline & & & & & -10 & -5 & 5 & 10 & \\
\hline & & & & & & PFN & Favours $\mathrm{C}$ & amma & \\
\hline
\end{tabular}




\section{Analysis I.9. Comparison I Proximal femoral nail (PFN) versus Gamma nail, Outcome 9 Mortality.}

Review: Intramedullary nails for extracapsular hip fractures in adults

Comparison: I Proximal femoral nail (PFN) versus Gamma nail

Outcome: 9 Mortality

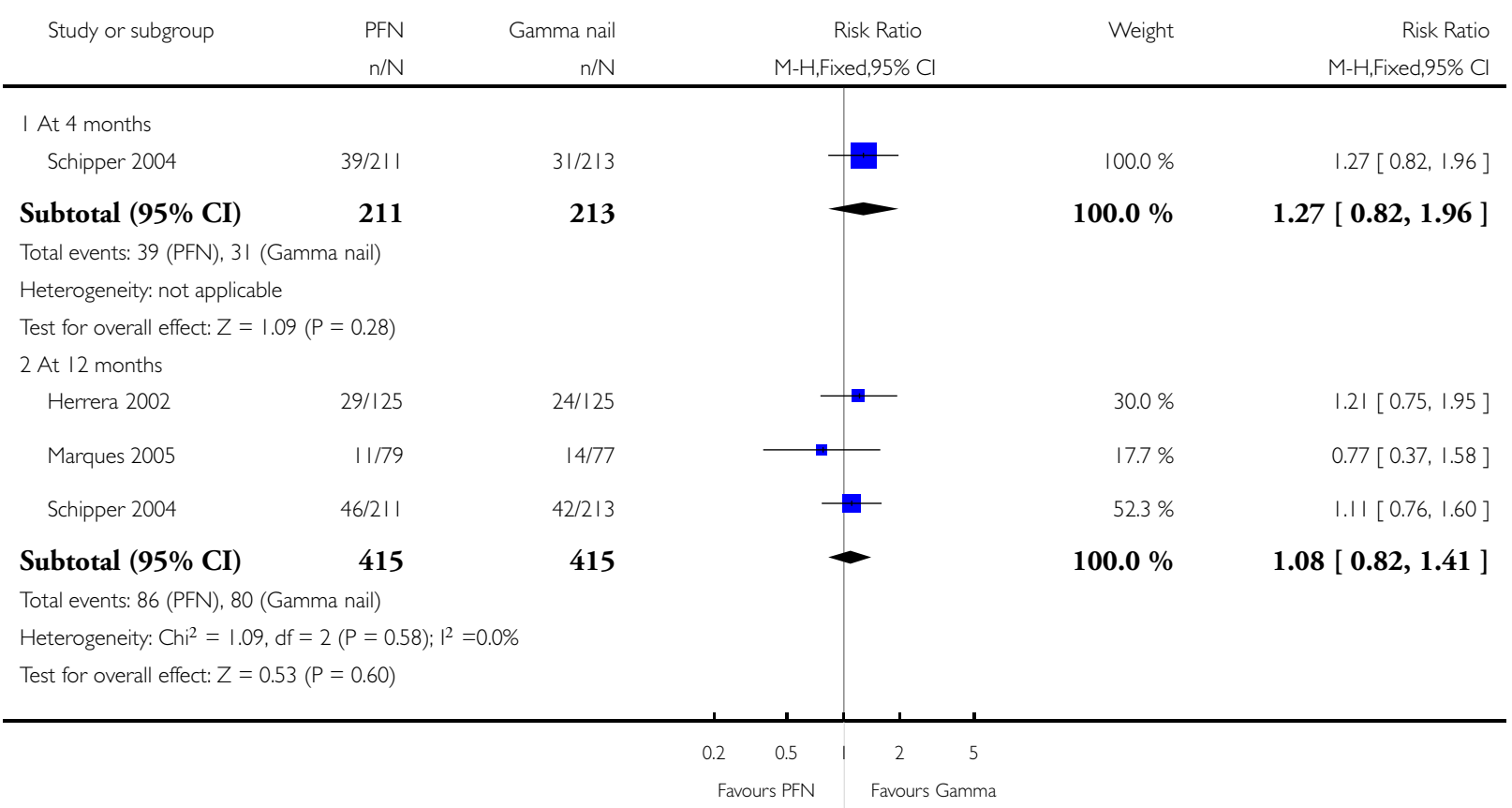


Analysis I.10. Comparison I Proximal femoral nail (PFN) versus Gamma nail, Outcome I0 Final functional outcomes.

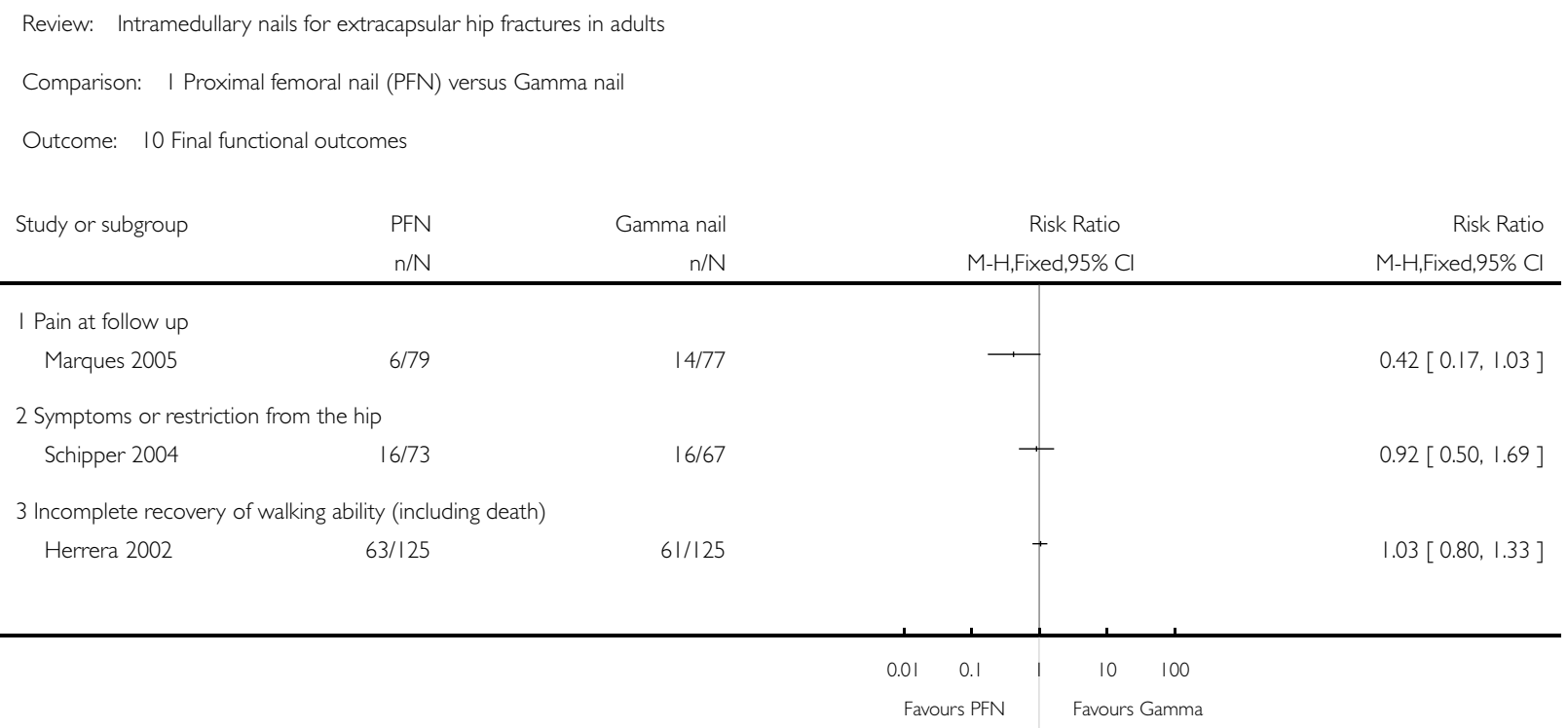

Analysis I.II. Comparison I Proximal femoral nail (PFN) versus Gamma nail, Outcome II Harris hip scores ( 0 to 100: high values $=$ best function).

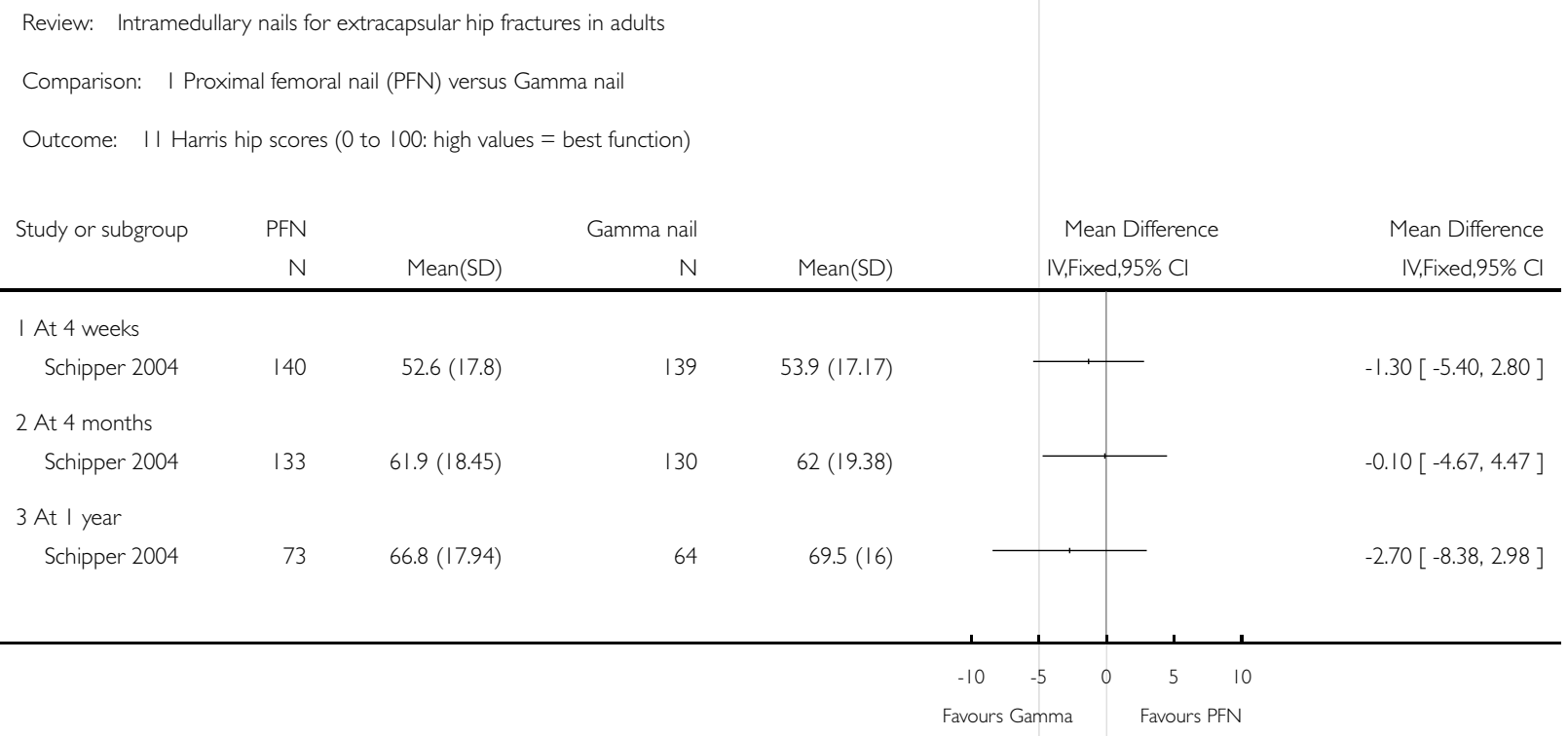


Analysis 2.I. Comparison 2 ACE trochanteric nail versus Gamma nail, Outcome I Operative details: length of surgery, blood loss and radiographic screening time.

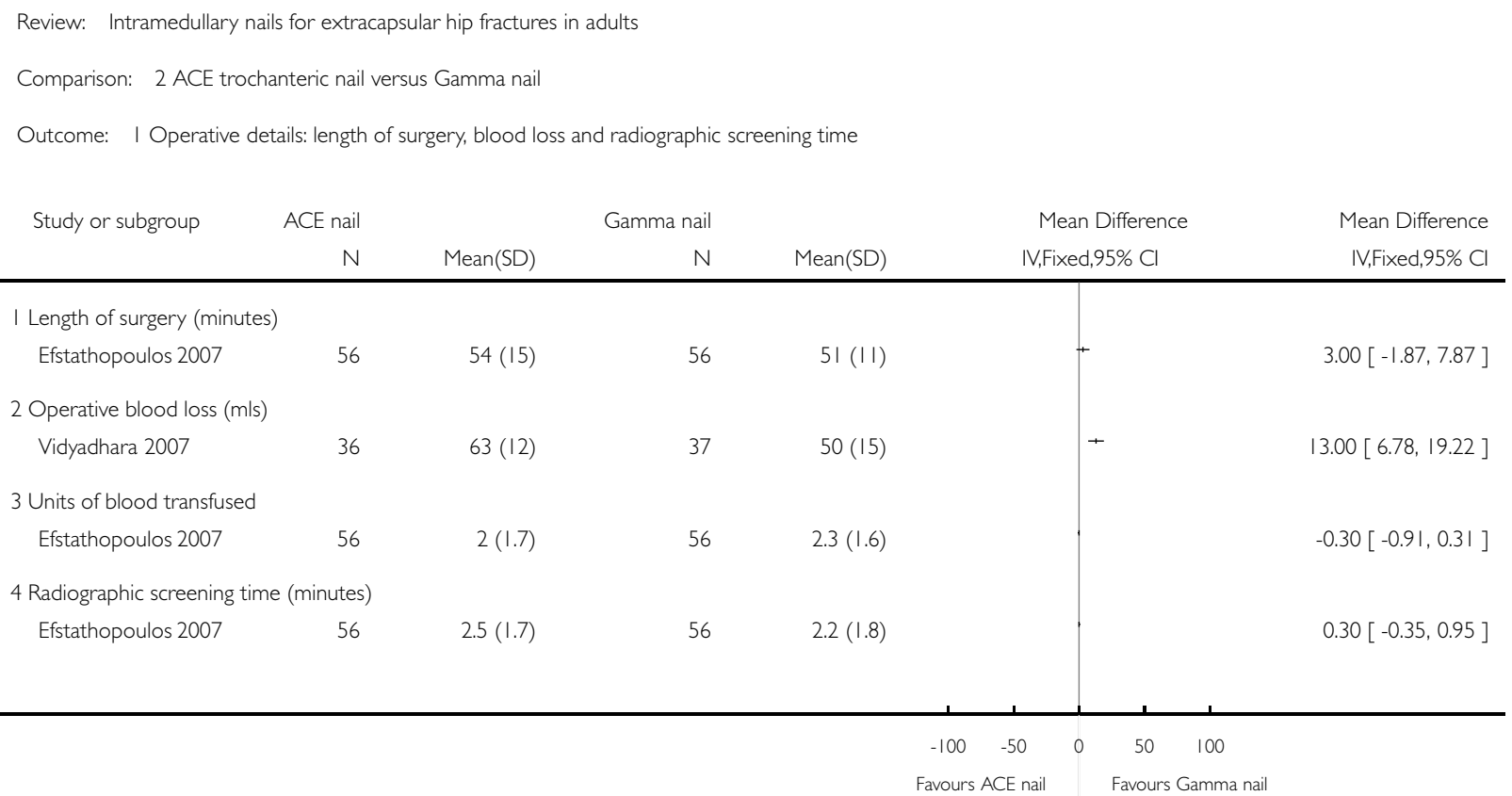

\section{Analysis 2.2. Comparison 2 ACE trochanteric nail versus Gamma nail, Outcome 2 Number of patients} transfused.

Review: Intramedullary nails for extracapsular hip fractures in adults

Comparison: 2 ACE trochanteric nail versus Gamma nail

Outcome: 2 Number of patients transfused

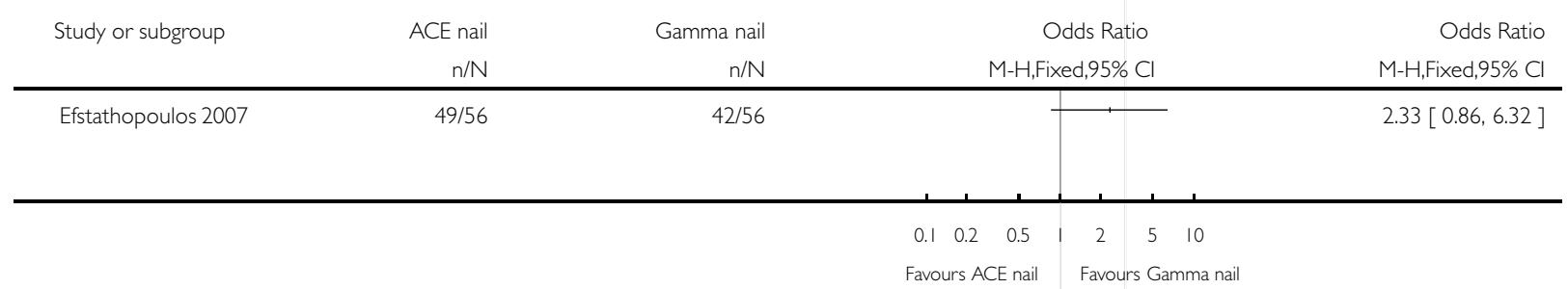


Analysis 2.3. Comparison 2 ACE trochanteric nail versus Gamma nail, Outcome 3 Fracture healing complications.

Review: Intramedullary nails for extracapsular hip fractures in adults

Comparison: 2 ACE trochanteric nail versus Gamma nail

Outcome: 3 Fracture healing complications

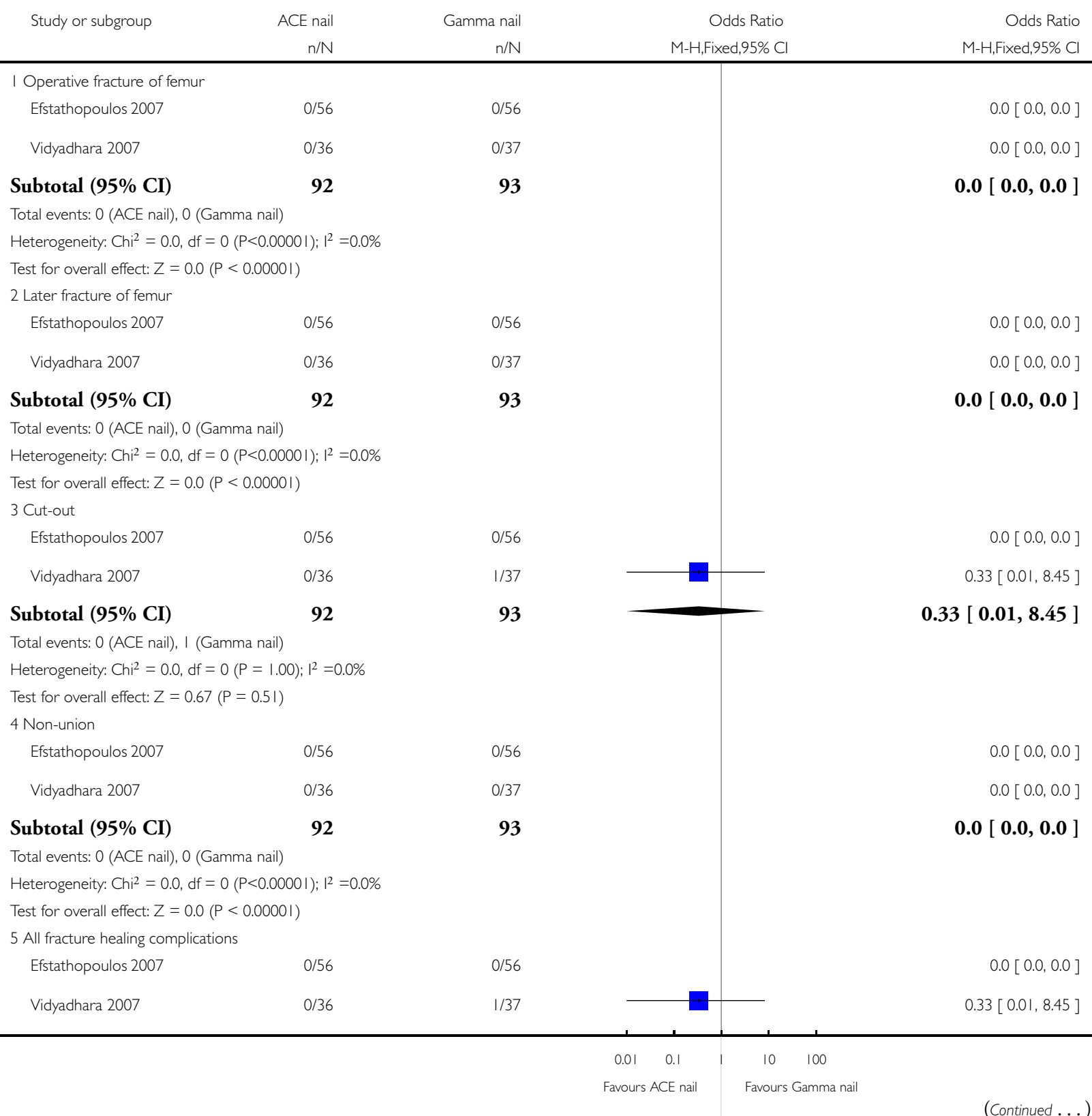




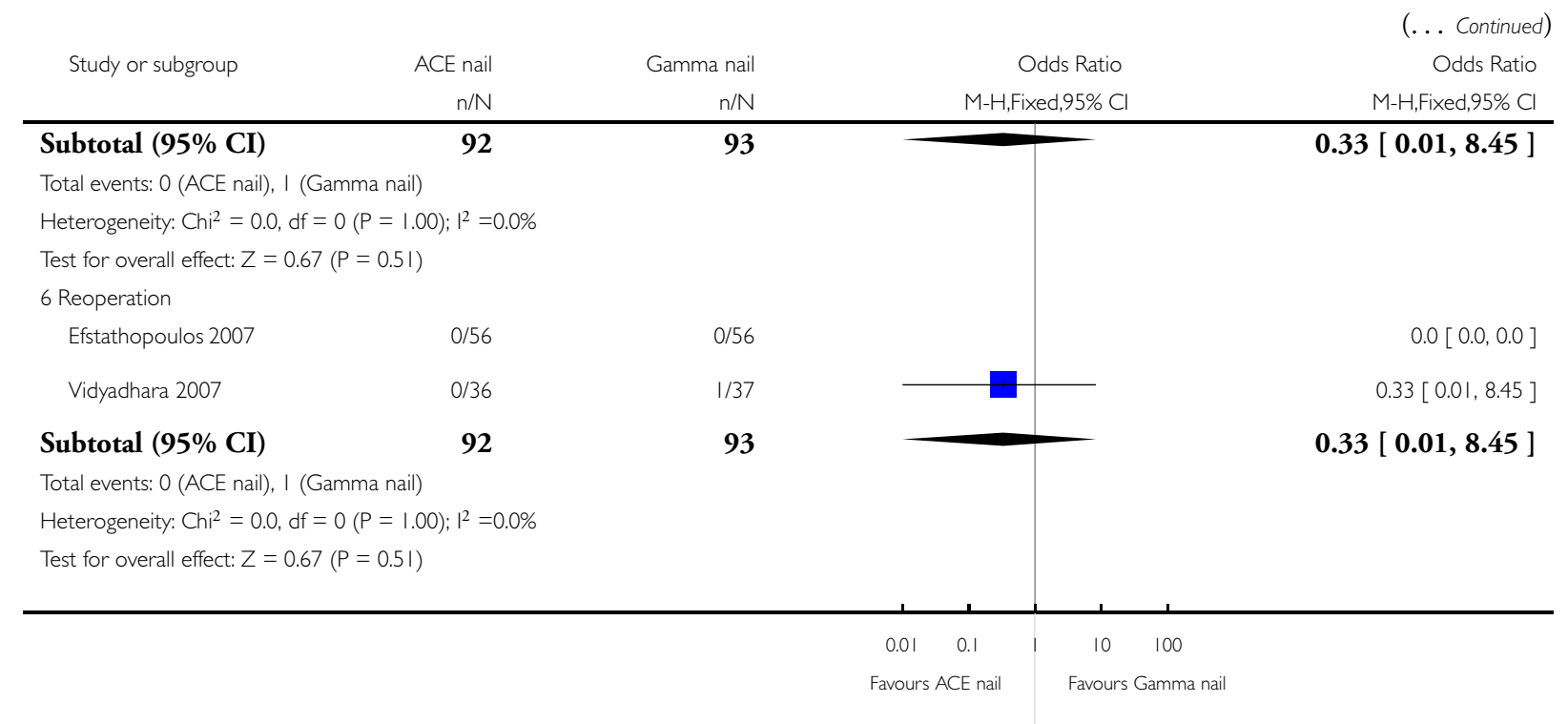

Analysis 2.4. Comparison 2 ACE trochanteric nail versus Gamma nail, Outcome 4 Wound complications.

Review: Intramedullary nails for extracapsular hip fractures in adults

Comparison: 2 ACE trochanteric nail versus Gamma nail

Outcome: 4 Wound complications

Study or subgroup $\quad$ ACE nail Gamma nail Odds Ratio Ods Ratio

$\mathrm{n} / \mathrm{N} \quad \mathrm{n} / \mathrm{N} \quad \mathrm{M}-\mathrm{H}$, Fixed,95\% Cl $\quad \mathrm{M}-\mathrm{H}$, Fixed,95\% Cl

\begin{tabular}{|c|c|c|c|}
\hline \multicolumn{4}{|l|}{ I All wound infection } \\
\hline Efstathopoulos 2007 & $4 / 56$ & $3 / 56$ & $1.36[0.29,6.37]$ \\
\hline Vidyadhara 2007 & $0 / 36$ & $0 / 37$ & $0.0[0.0,0.0]$ \\
\hline Subtotal (95\% CI) & 92 & 93 & $1.36[0.29,6.37]$ \\
\hline \multicolumn{4}{|c|}{ Total events: 4 (ACE nail), 3 (Gamma nail) } \\
\hline \multicolumn{4}{|c|}{ Heterogeneity: $\mathrm{Chi}^{2}=0.0, \mathrm{df}=0(\mathrm{P}=1.00) ;\left.\right|^{2}=0.0 \%$} \\
\hline \multicolumn{4}{|c|}{ Test for overall effect: $Z=0.39(P=0.70)$} \\
\hline \multicolumn{4}{|l|}{2 Deep wound infection } \\
\hline Efstathopoulos 2007 & $0 / 56$ & $0 / 56$ & $0.0[0.0,0.0]$ \\
\hline Vidyadhara 2007 & $0 / 36$ & $0 / 37$ & $0.0[0.0,0.0]$ \\
\hline Subtotal (95\% CI) & 92 & 93 & $0.0[0.0,0.0]$ \\
\hline \multicolumn{4}{|c|}{ Total events: 0 (ACE nail), 0 (Gamma nail) } \\
\hline \multicolumn{4}{|c|}{ Heterogeneity: $\mathrm{Chi}^{2}=0.0, \mathrm{df}=0(\mathrm{P}<0.0000 \mathrm{I}) ; \mathrm{I}^{2}=0.0 \%$} \\
\hline Test for overall effect: $Z=$ & & & \\
\hline
\end{tabular}

$\begin{array}{lllllll}0.1 & 0.2 & 0.5 & 1 & 2 & 5 & 10\end{array}$

Favours ACE nail Favours Gamma nail 


\section{Analysis 2.5. Comparison 2 ACE trochanteric nail versus Gamma nail, Outcome 5 Post-operative}

complications.

Review: Intramedullary nails for extracapsular hip fractures in adults

Comparison: 2 ACE trochanteric nail versus Gamma nail

Outcome: 5 Post-operative complications

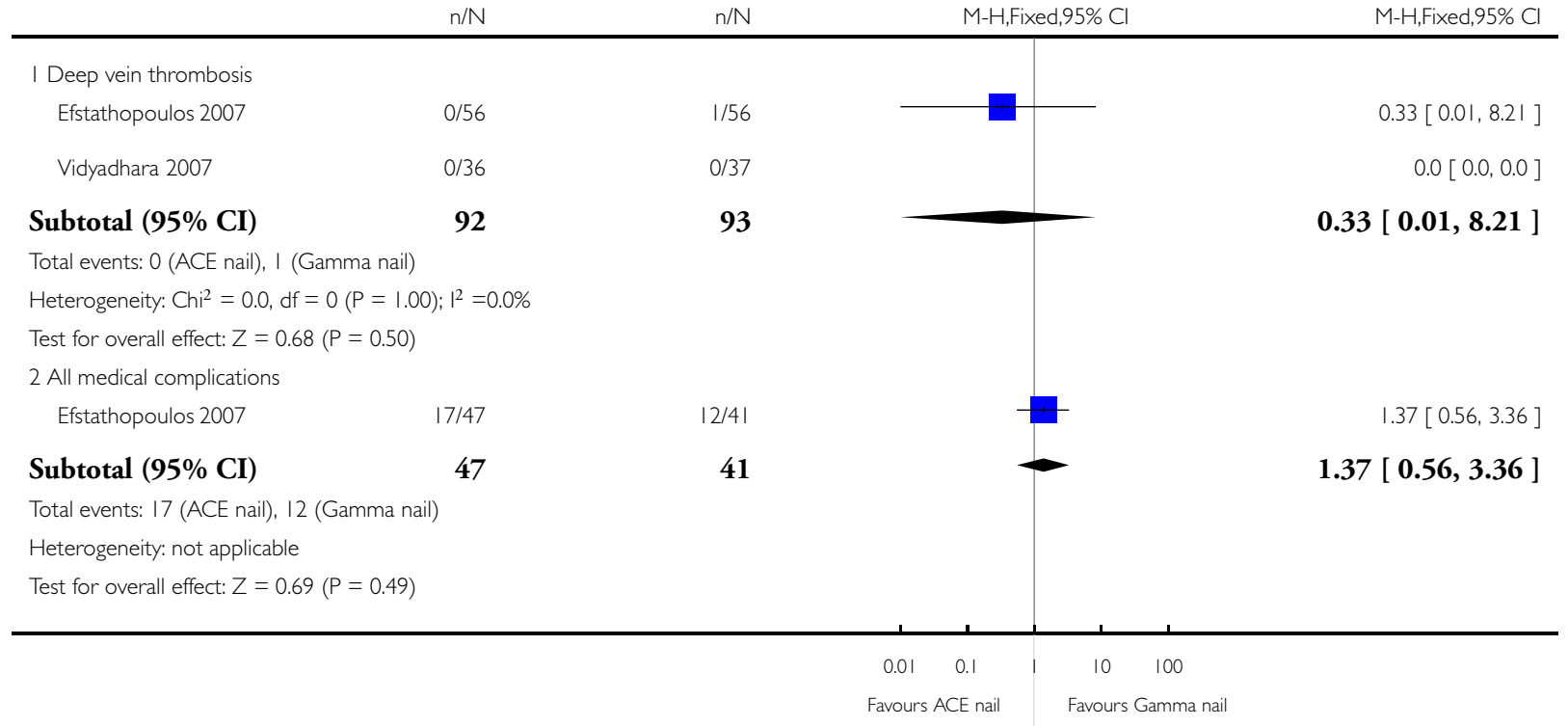

Analysis 2.6. Comparison 2 ACE trochanteric nail versus Gamma nail, Outcome 6 Anatomical restoration.

Review: Intramedullary nails for extracapsular hip fractures in adults

Comparison: 2 ACE trochanteric nail versus Gamma nail

Outcome: 6 Anatomical restoration

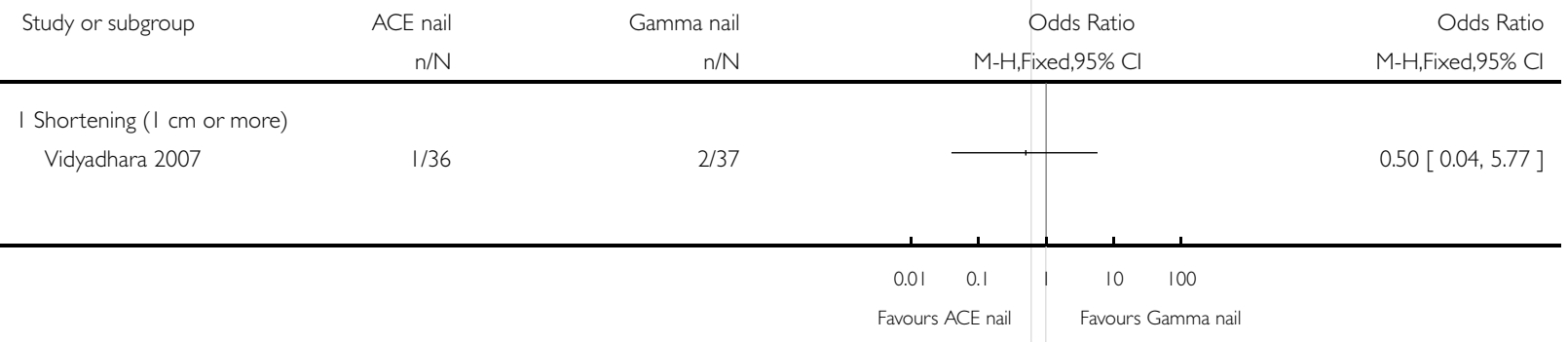


Analysis 2.7. Comparison 2 ACE trochanteric nail versus Gamma nail, Outcome 7 Mortality.

Review: Intramedullary nails for extracapsular hip fractures in adults

Comparison: 2 ACE trochanteric nail versus Gamma nail

Outcome: 7 Mortality

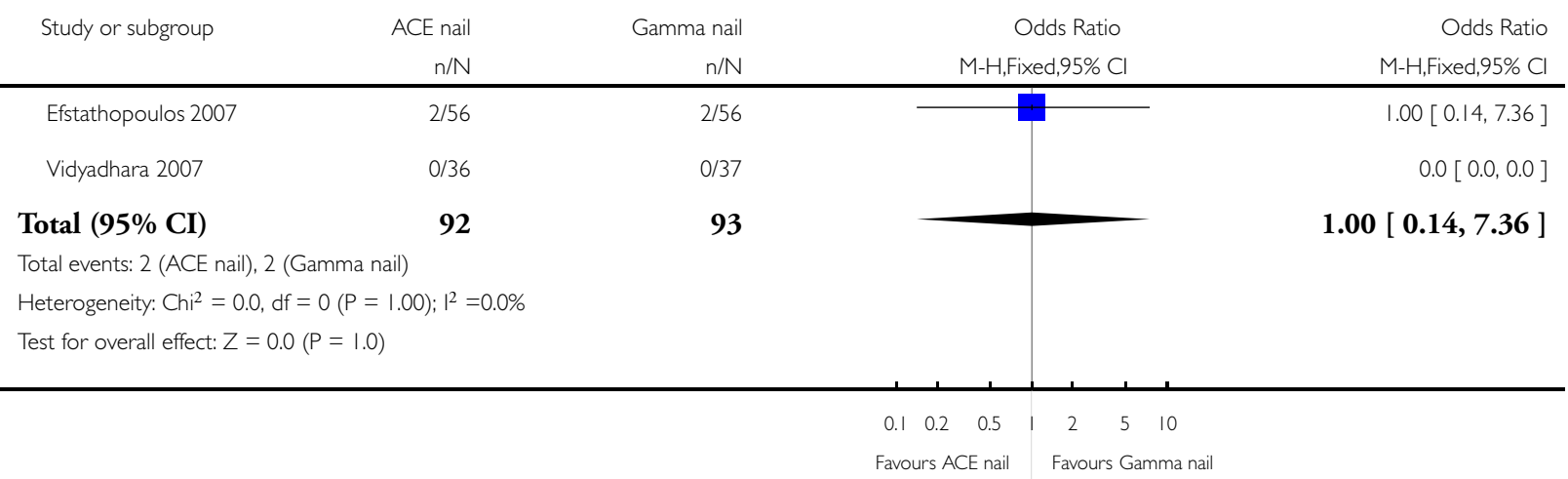

Analysis 2.8. Comparison 2 ACE trochanteric nail versus Gamma nail, Outcome 8 Final functional outcomes.

Review: Intramedullary nails for extracapsular hip fractures in adults

Comparison: 2 ACE trochanteric nail versus Gamma nail

Outcome: 8 Final functional outcomes

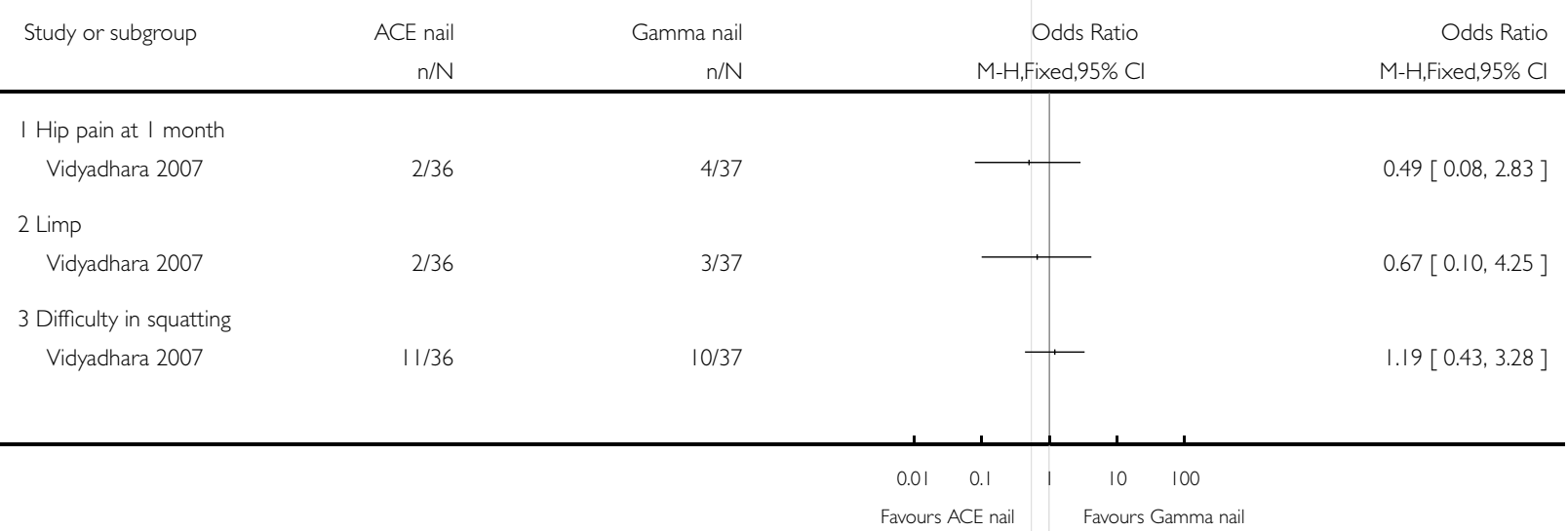


Analysis 2.9. Comparison 2 ACE trochanteric nail versus Gamma nail, Outcome 9 Mobility score (0: no difficulties to 9: most difficulties).

Review: Intramedullary nails for extracapsular hip fractures in adults

Comparison: 2 ACE trochanteric nail versus Gamma nail

Outcome: 9 Mobility score (0: no difficulties to 9: most difficulties)

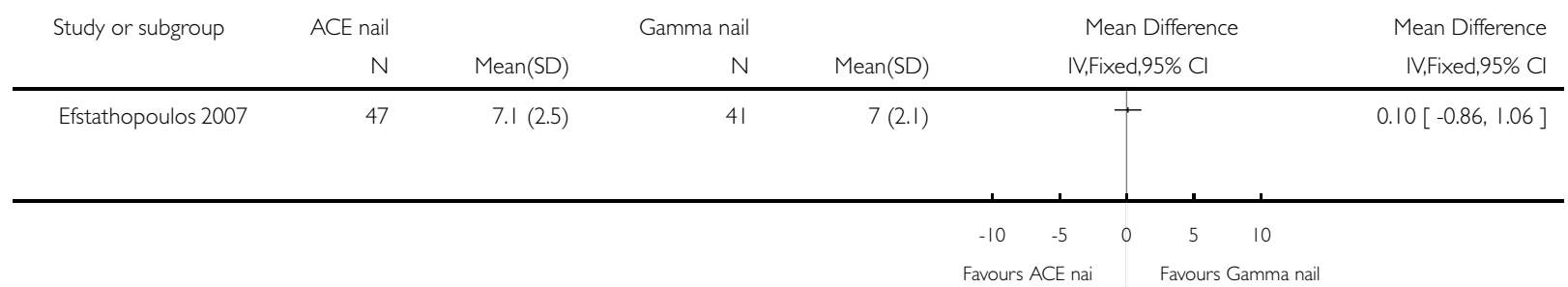

Analysis 2.10. Comparison 2 ACE trochanteric nail versus Gamma nail, Outcome 10 Harris hip scores (0 to 100: high values $=$ best function).

Review: Intramedullary nails for extracapsular hip fractures in adults

Comparison: 2 ACE trochanteric nail versus Gamma nail

Outcome: 10 Harris hip scores (0 to 100: high values = best function)

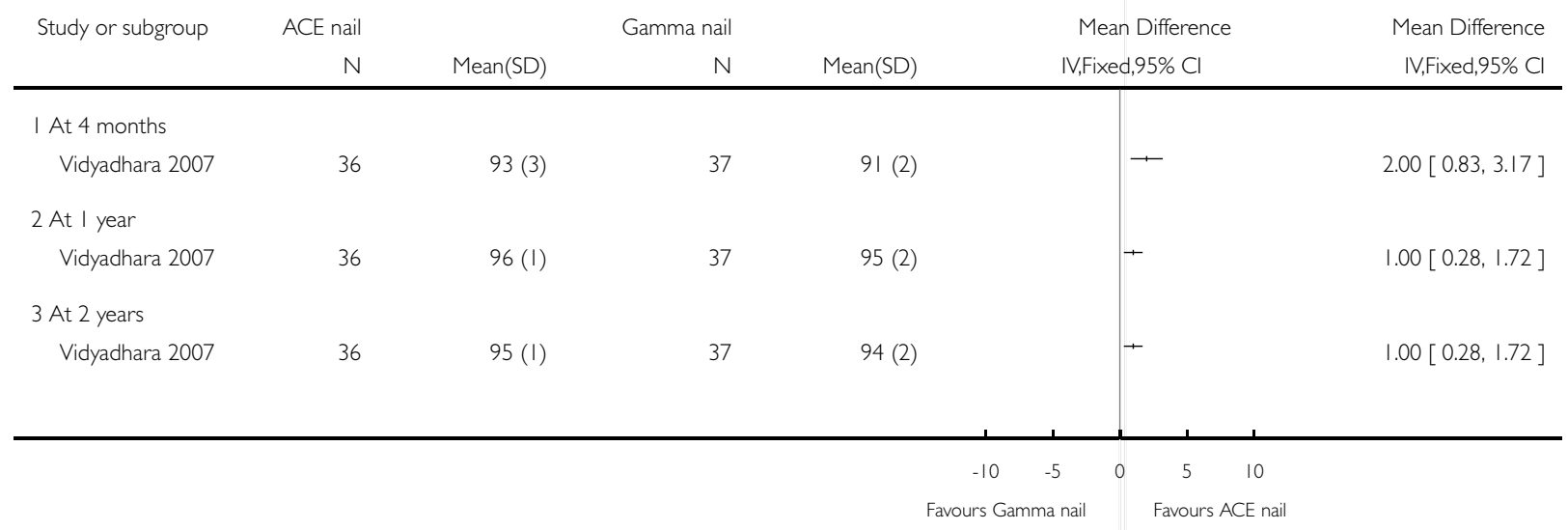


Analysis 3.I. Comparison 3 Gliding nail versus Gamma nail, Outcome I Fracture fixation complications. Review: Intramedullary nails for extracapsular hip fractures in adults

Comparison: 3 Gliding nail versus Gamma nail

Outcome: I Fracture fixation complications

\begin{tabular}{|c|c|c|c|c|}
\hline \multirow[t]{2}{*}{ Study or subgroup } & \multirow{2}{*}{$\begin{array}{r}\text { Gliding nail } \\
n / N\end{array}$} & \multirow{2}{*}{$\begin{array}{r}\text { Gamma nail } \\
n / N\end{array}$} & \multirow{2}{*}{$\begin{array}{c}\text { Risk Ratio } \\
\text { M-H,Fixed,95\% Cl }\end{array}$} & \multirow{2}{*}{$\begin{array}{r}\text { Risk Ratio } \\
\text { M-H,Fixed,95\% Cl }\end{array}$} \\
\hline & & & & \\
\hline \multicolumn{5}{|c|}{ I Operative fracture of femur } \\
\hline Fritz 1999 & $1 / 40$ & $0 / 40$ & & $3.00[0.13,71.51]$ \\
\hline \multicolumn{5}{|c|}{2 Later fracture of femur } \\
\hline Fritz 1999 & $1 / 40$ & $0 / 40$ & & $3.00[0.13,71.51]$ \\
\hline \multicolumn{5}{|l|}{3 Cut-out } \\
\hline Fritz 1999 & $0 / 40$ & $3 / 40$ & - & $0.14[0.01,2.68]$ \\
\hline \multicolumn{5}{|c|}{4 Technical complications of fixation } \\
\hline Fritz 1999 & $2 / 40$ & $3 / 40$ & - & $0.67[0.12,3.78]$ \\
\hline \multicolumn{5}{|l|}{5 Reoperation } \\
\hline Fritz 1999 & $3 / 40$ & $4 / 40$ & $\longrightarrow$ & $0.75[0.18,3.14]$ \\
\hline
\end{tabular}

$0.0010 .01 \quad 0.1 \quad 1 \quad 10 \quad 100 \quad 1000$

Favours gliding Favours Gamma 
Analysis 3.2. Comparison 3 Gliding nail versus Gamma nail, Outcome 2 Post-operative complications.

\begin{tabular}{|c|c|c|c|c|}
\hline \multicolumn{5}{|c|}{ Comparison: 3 Gliding nail versus Gamma nail } \\
\hline \multicolumn{5}{|c|}{ Outcome: 2 Post-operative complications } \\
\hline \multirow[t]{2}{*}{ Study or subgroup } & Gliding nail & Gamma nail & Risk Ratio & Risk Ratio \\
\hline & $\mathrm{n} / \mathrm{N}$ & $\mathrm{n} / \mathrm{N}$ & M-H,Fixed,95\% Cl & M-H,Fixed,95\% Cl \\
\hline \multicolumn{5}{|c|}{ I Participants with a complication } \\
\hline Fritz 1999 & $9 / 40$ & $6 / 40$ & + & $1.50[0.59,3.82]$ \\
\hline \multicolumn{5}{|c|}{2 Pressure sores (decubitus) } \\
\hline Fritz 1999 & $2 / 40$ & $2 / 40$ & 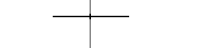 & $1.00[0.15,6.76]$ \\
\hline \multicolumn{5}{|l|}{3 Pneumonia } \\
\hline Fritz 1999 & $1 / 40$ & $1 / 40$ & & $1.00[0.06,15.44]$ \\
\hline \multicolumn{5}{|c|}{4 Cerebrovascular accident } \\
\hline Fritz 1999 & $2 / 40$ & $1 / 40$ & & $2.00[0.19,21.18]$ \\
\hline \multicolumn{5}{|l|}{5 Apoplexy } \\
\hline Fritz 1999 & $1 / 40$ & $0 / 40$ & & $3.00[0.13,71.51]$ \\
\hline \multicolumn{5}{|l|}{6 Forearm fracture } \\
\hline Fritz 1999 & $1 / 40$ & $0 / 40$ & & $3.00[0.13,71.51]$ \\
\hline
\end{tabular}

Analysis 3.3. Comparison 3 Gliding nail versus Gamma nail, Outcome 3 Anatomical deformity.

Review: Intramedullary nails for extracapsular hip fractures in adults

Comparison: 3 Gliding nail versus Gamma nail

Outcome: 3 Anatomical deformity

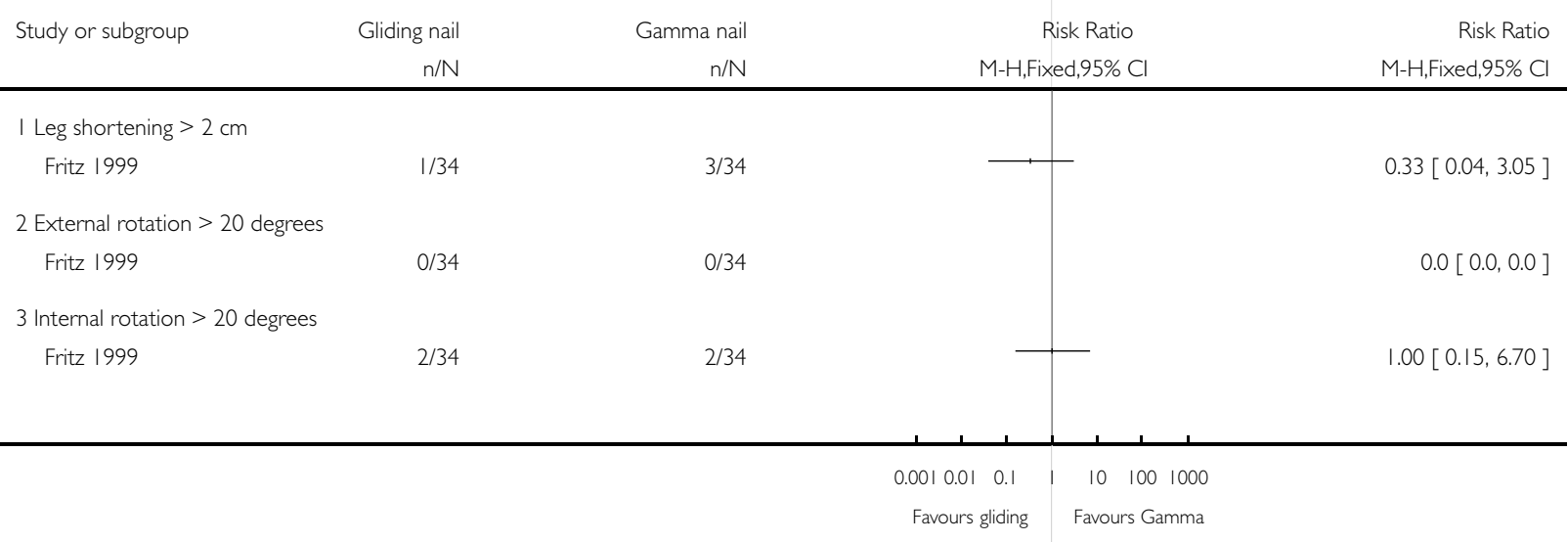




\section{Analysis 3.4. Comparison 3 Gliding nail versus Gamma nail, Outcome 4 Mortality at 6 months.}

Review: Intramedullary nails for extracapsular hip fractures in adults

Comparison: 3 Gliding nail versus Gamma nail

Outcome: 4 Mortality at 6 months

\begin{tabular}{|c|c|c|c|c|}
\hline \multirow[t]{2}{*}{ Study or subgroup } & Gliding nail & Gamma nail & Risk Ratio & Risk Ratio \\
\hline & $n / N$ & $\mathrm{n} / \mathrm{N}$ & M-H,Fixed,95\% Cl & M-H,Fixed,95\% Cl \\
\hline Fritz 1999 & $6 / 40$ & $5 / 40$ & - & $1.20[0.40,3.62]$ \\
\hline
\end{tabular}

Analysis 3.5. Comparison 3 Gliding nail versus Gamma nail, Outcome 5 Residence and unfavourable outcome (geriatric institution or death) at 6 months.

Review: Intramedullary nails for extracapsular hip fractures in adults

Comparison: 3 Gliding nail versus Gamma nail

Outcome: 5 Residence and unfavourable outcome (geriatric institution or death) at 6 months

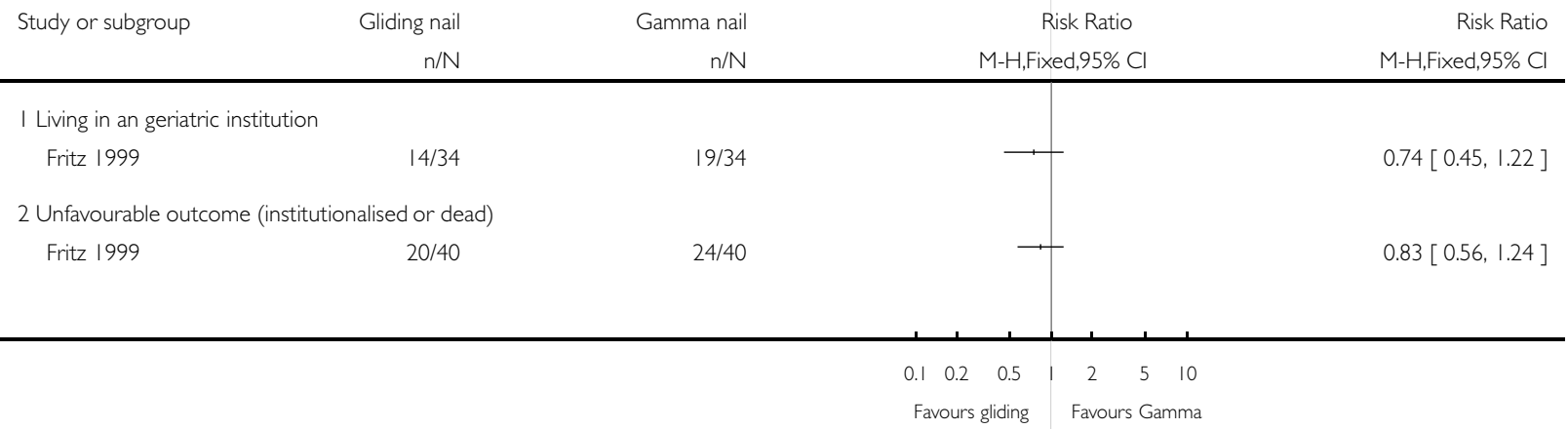


Analysis 4.I. Comparison 4 Russell-Taylor Recon nail versus long Gamma nail, Outcome I Fracture healing and wound healing complications.

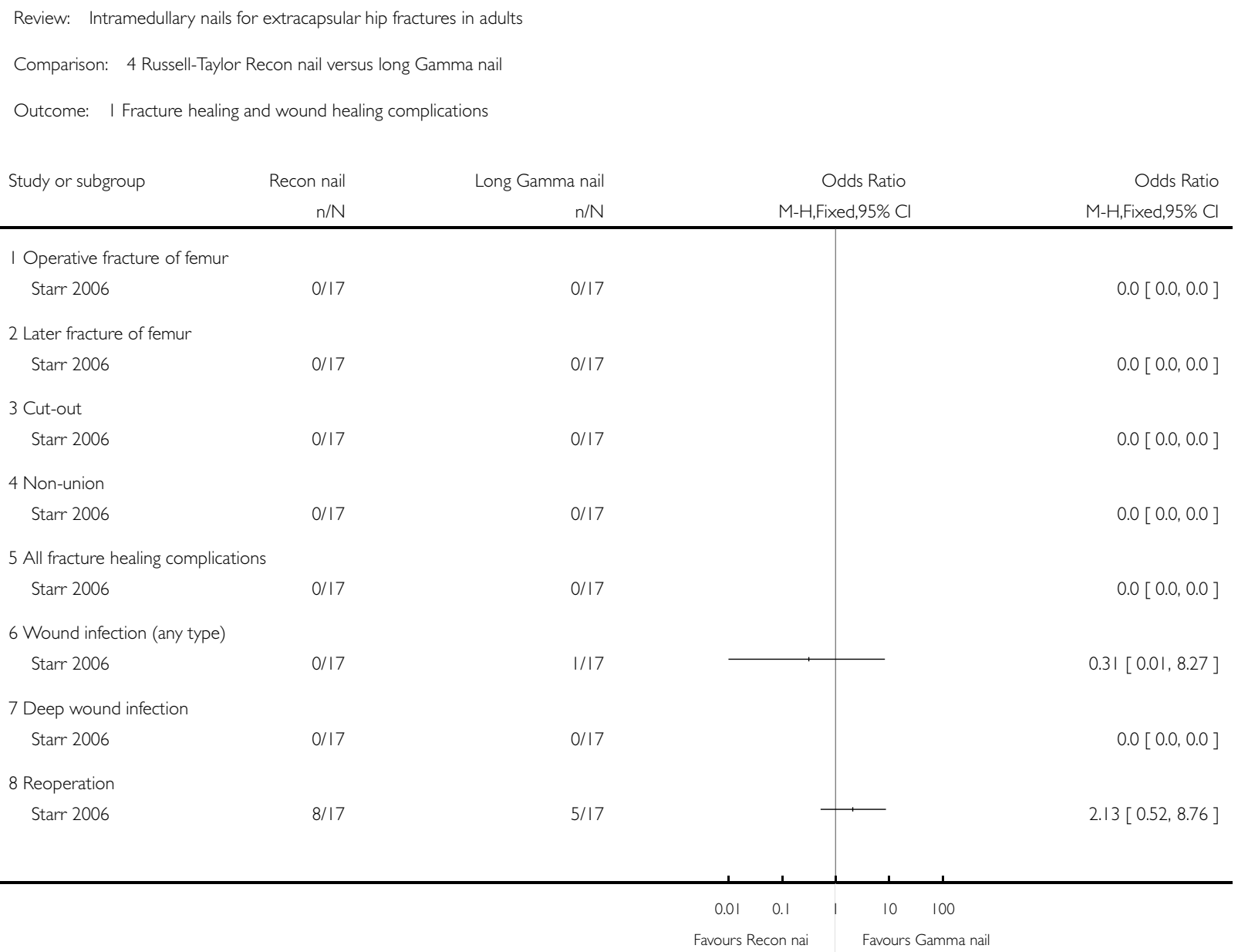


Analysis 4.2. Comparison 4 Russell-Taylor Recon nail versus long Gamma nail, Outcome 2 Final outcome measures.

Review: Intramedullary nails for extracapsular hip fractures in adults

Comparison: 4 Russell-Taylor Recon nail versus long Gamma nail

Outcome: 2 Final outcome measures

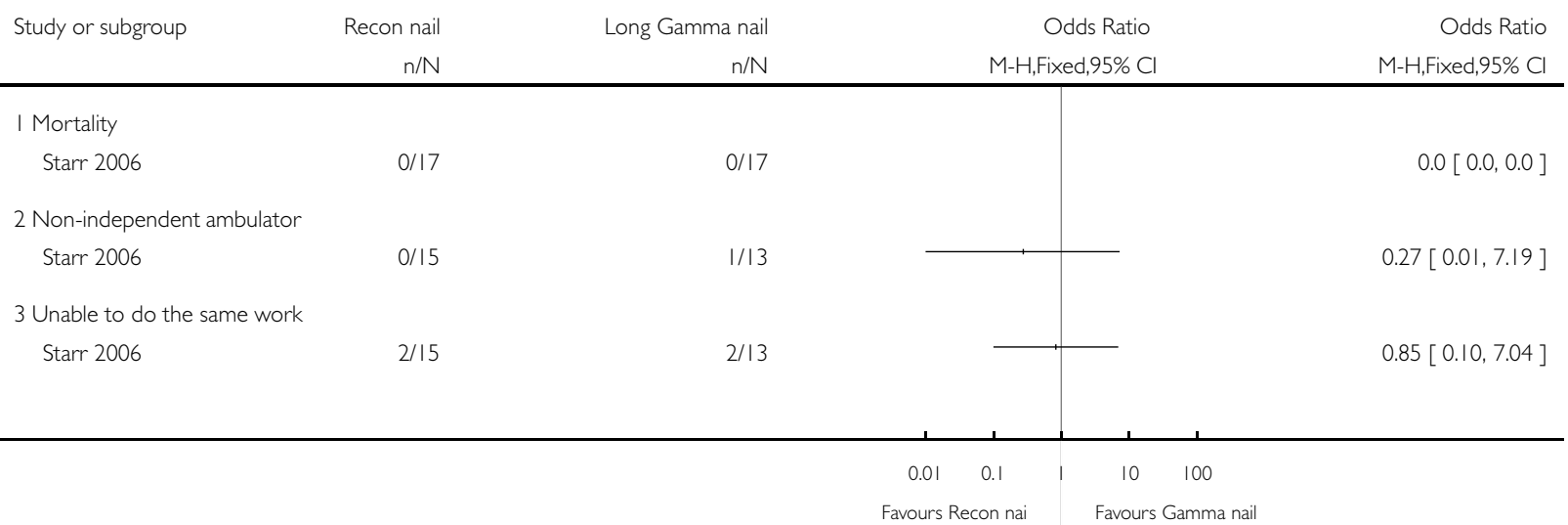

Analysis 5.I. Comparison 5 Dynamic versus static locked intramedullary nail, Outcome I Operative details.

Review: Intramedullary nails for extracapsular hip fractures in adults

Comparison: 5 Dynamic versus static locked intramedullary nail

Outcome: I Operative details

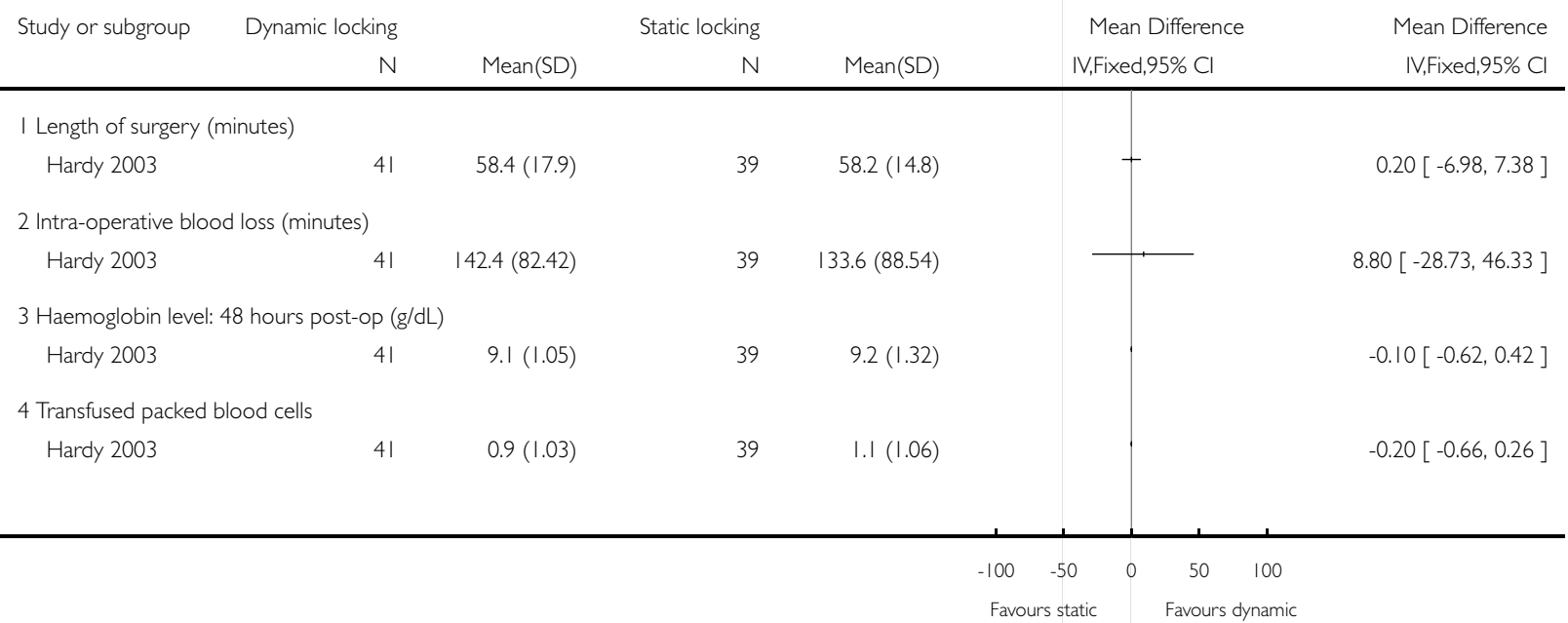


Analysis 5.2. Comparison 5 Dynamic versus static locked intramedullary nail, Outcome 2 Fracture fixation complications.

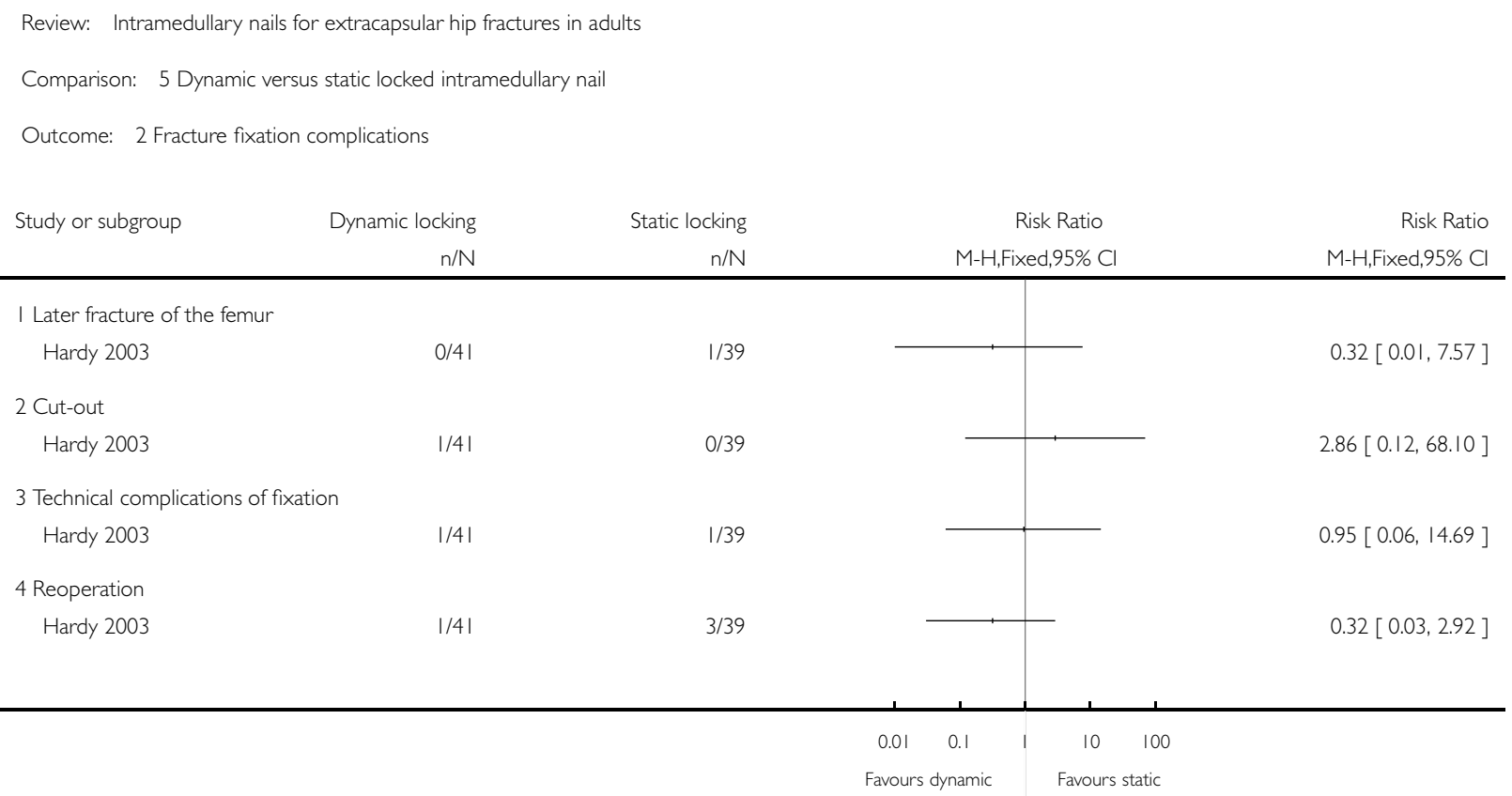

Analysis 5.3. Comparison 5 Dynamic versus static locked intramedullary nail, Outcome 3 Leg shortening $(\mathrm{mm})$ in those able to undergo a radiographic assessment.

Review: Intramedullary nails for extracapsular hip fractures in adults

Comparison: 5 Dynamic versus static locked intramedullary nail

Outcome: 3 Leg shortening $(\mathrm{mm})$ in those able to undergo a radiographic assessment

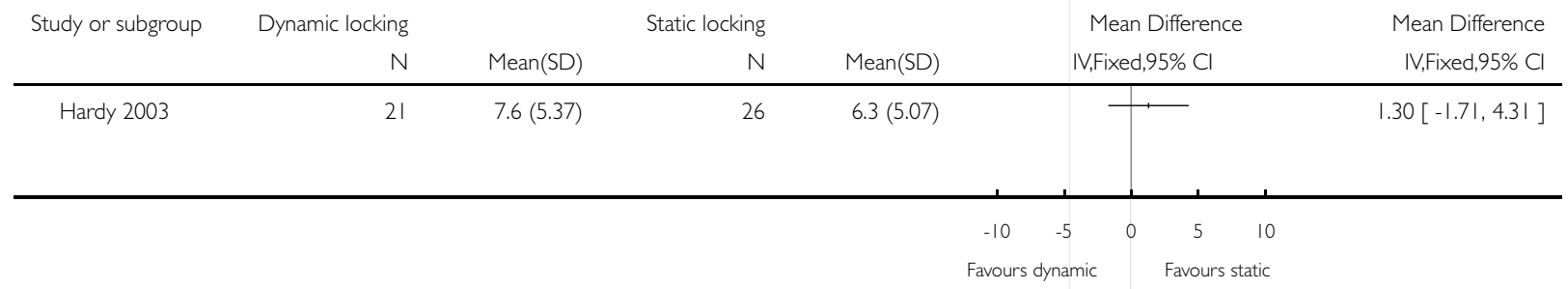


Analysis 5.4. Comparison 5 Dynamic versus static locked intramedullary nail, Outcome 4 Mortality at I year.

Review: Intramedullary nails for extracapsular hip fractures in adults

Comparison: 5 Dynamic versus static locked intramedullary nail

Outcome: 4 Mortality at I year

\begin{tabular}{|c|c|c|c|c|}
\hline Study or subgroup & $\begin{array}{r}\text { Dynamic locking } \\
n / N\end{array}$ & $\begin{array}{r}\text { Static locking } \\
\mathrm{n} / \mathrm{N}\end{array}$ & $\begin{array}{c}\text { Risk Ratio } \\
\text { M-H,Fixed,95\% Cl }\end{array}$ & $\begin{array}{r}\text { Risk Ratio } \\
\text { M-H.Fixed,95\% Cl }\end{array}$ \\
\hline Hardy 2003 & $7 / 41$ & $9 / 39$ & - & $0.74[0.31,1.79]$ \\
\hline
\end{tabular}

Analysis 5.5. Comparison 5 Dynamic versus static locked intramedullary nail, Outcome 5 Pain and cortical hypertrophy.

Review: Intramedullary nails for extracapsular hip fractures in adults

Comparison: 5 Dynamic versus static locked intramedullary nail

Outcome: 5 Pain and cortical hypertrophy

Study or subgroup $\quad$ Dynamic locking $\quad$ Static locking Risk Ratio Ratio $\mathrm{n} / \mathrm{N} \quad \mathrm{n} / \mathrm{N} \quad \mathrm{M}-\mathrm{H}$, Fixed,95\% Cl $\quad \mathrm{M}-\mathrm{H}$, Fixed,95\% Cl

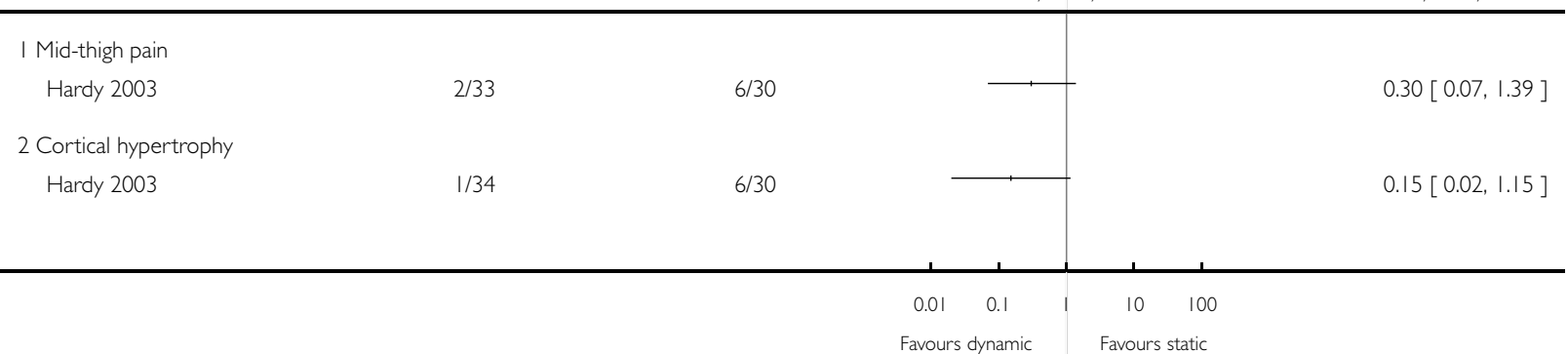




\section{A P P E N D I CES}

\section{Appendix I. Search strategies (The Cochrane Library, MEDLINE and EMBASE)}

\begin{tabular}{|c|c|c|}
\hline The Cochrane Library & MEDLINE (OVID WEB) & EMBASE (OVID WEB) \\
\hline $\begin{array}{l}\text { \#1 MeSH descriptor Hip Fractures explode } \\
\text { all trees } \\
\# 2 \text { ((hip* or femur* or femoral* or } \\
\text { trochant* or pertrochant* or intertrochant* } \\
\text { or subtrochant* or intracapsular* or extra- } \\
\text { capsular*)NEAR fracture*):ti,ab,kw } \\
\text { \#3 (\#1 OR \#2) } \\
\text { \#4 } 4 \text { (pin* or nail }{ }^{*} \text { or screw* or plate* or } \\
\text { arthroplasty* or fix* or prosthes*):ti,ab,kw } \\
\text { \#5 MeSH descriptor Internal Fixators, this } \\
\text { term only } \\
\text { \#6 MeSH descriptor Bone Screws, this } \\
\text { term only } \\
\text { \#7 MeSH descriptor Fracture Fixation, In- } \\
\text { ternal explode all trees } \\
\text { \#8 MeSH descriptor Bone Plates, this term } \\
\text { only } \\
\# 9 \text { MeSH descriptor Bone Nails, this term } \\
\text { only } \\
\text { \#10 MeSH descriptor Arthroplasty ex- } \\
\text { plode all trees } \\
\# 11 \text { (\#4 OR \#5 OR \#6 OR \#7 OR \#8 OR } \\
\# 9 \text { OR \#10) } \\
\text { \#12 (\#3 AND \#11) }\end{array}$ & $\begin{array}{l}\text { 1. exp Hip Fractures/ } \\
\text { 2. hip } \$ \text { or femur } \$ \text { or femoral } \$ \text { or trochant } \$ \\
\text { or pertrochant } \$ \text { or intertrochant } \$ \text { or sub- } \\
\text { trochant } \$ \text { or intracapsular } \$ \text { or extracapsu- } \\
\text { lar } \$ \text { )adj } 4 \text { fracture } \$ \text { ).tw. } \\
\text { 3. or } / 1-2 \\
\text { 4. (pin } \$ 1 \text { or nail } \$ \text { or screw } \$ 1 \text { or plate } \$ 1 \text { or } \\
\text { arthroplast } \$ \text { or fix } \$ \text { or prosthes } \$ \text { ).tw. } \\
\text { 5. Internal Fixators/ or Bone Screws/ or } \\
\text { Fracture Fixation, Internal/ or Bone Plates/ } \\
\text { or Bone Nails/ } \\
\text { 6. Arthroplasty/or Arthroplasty, Replace- } \\
\text { ment, Hip/ } \\
\text { 7. or } / 4-6 \\
\text { 8. and } / 3,7\end{array}$ & 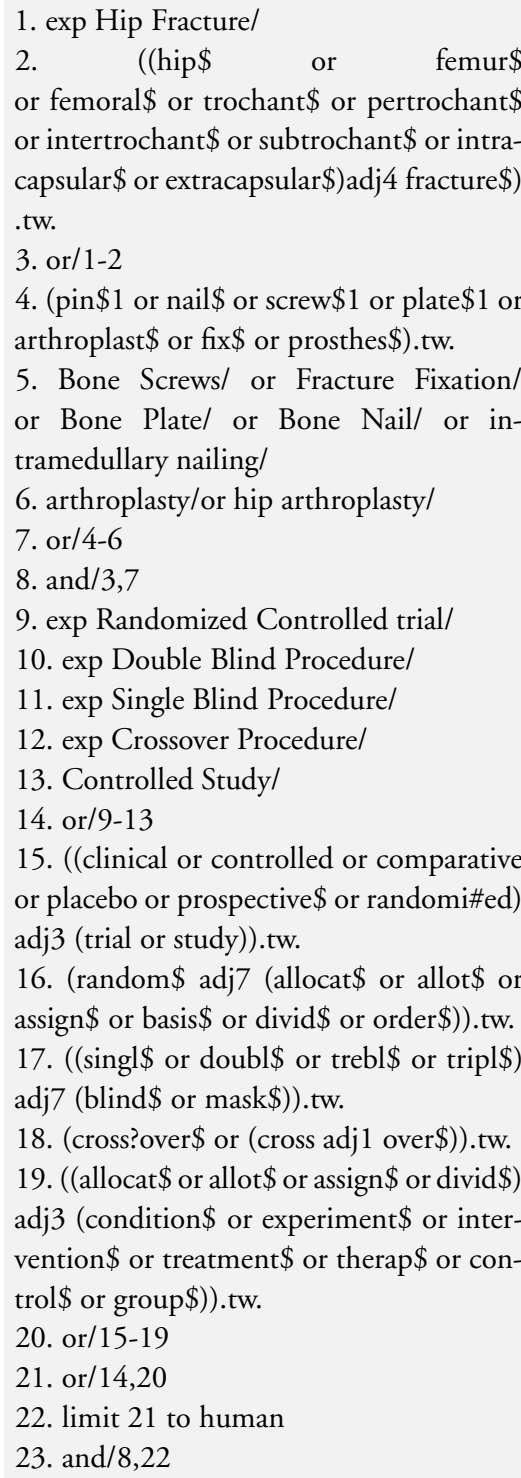 \\
\hline
\end{tabular}




\section{WHAT'S NEW}

Last assessed as up-to-date: 28 June 2007.

\begin{tabular}{|c|c|c|}
\hline 31 July 2008 & New search has been performed & $\begin{array}{l}\text { For the second update, published in Issue } 4,2008 \text {, the following changes were } \\
\text { made: } \\
\text { (1) the search was updated to June } 2007 \text {; } \\
\text { (2) three newly identified studies (Efstathopoulos } 2007 \text {, Starr 2006, Vidadhura } \\
\text { 2007) were included resulting in the addition of two new comparisons; } \\
\text { (3) one newly identified study (Suckel 2006) was excluded. } \\
\text { There were no changes made to the conclusions. }\end{array}$ \\
\hline 30 July 2008 & Amended & Converted to new review format. \\
\hline
\end{tabular}

\section{H I S T O R Y}

Protocol first published: Issue 4, 2004

Review first published: Issue 2, 2005

\begin{tabular}{|c|c|c|}
\hline 17 May 2006 & New search has been performed & $\begin{array}{l}\text { For the first update, published in Issue 3,2006, the following changes were made: } \\
\text { (1) the search was updated to March 2006; } \\
\text { (2) two new studies (Marques 2005; Papasimos 2005) were included; } \\
\text { (3) additional data were included from Schipper } 2004 \text { after correspondence with } \\
\text { trialists; } \\
\text { (4) adjustments were made to text and tables to conform to revised methodology } \\
\text { and the Cochrane Style Guide. } \\
\text { There were no changes made to the conclusions. }\end{array}$ \\
\hline
\end{tabular}

\section{CONTRIBUTIONSOFAUTHORS}

Martyn Parker initiated the review and wrote the first draft of the protocol. Helen Handoll revised the protocol. Both authors identified trials, selected trials for inclusion, performed data extraction and quality assessment of the included trials. Martyn Parker compiled the first draft of the review and review updates: these were then critically revised and completed by Helen Handoll. Both reviewers are guarantors of the review. 


\section{DECLARATIONS OF INTEREST}

None known.

\section{SOURCES OF SUPPORT}

\section{Internal sources}

- University of Teesside, Middlesbrough, UK.

- Peterborough and Stamford Hospitals NHS Foundation Trust, UK.

\section{External sources}

- No sources of support supplied

\section{DIFFERENCES BETWEEN PROTOCOLANDREVIEW}

The title of the review was changed in Issue 2, 2005 from that of the protocol (Cephalocondylic intramedullary nails for extracapsular hip fractures in adults) to the present title. This reflected the expansion of the scope to include condylocephalic nails.

\section{NDEX TERMS}

\section{Medical Subject Headings (MeSH)}

*Bone Nails; Fracture Fixation, Intramedullary [instrumentation; * methods]; Hip Fractures [ ${ }^{*}$ surgery]; Randomized Controlled Trials as Topic

\section{MeSH check words}

Aged; Female; Humans; Male 